POLISH ACADEMY OF SCIENCES

MUSEUM AND INSTITUTE OF ZOOLOGY

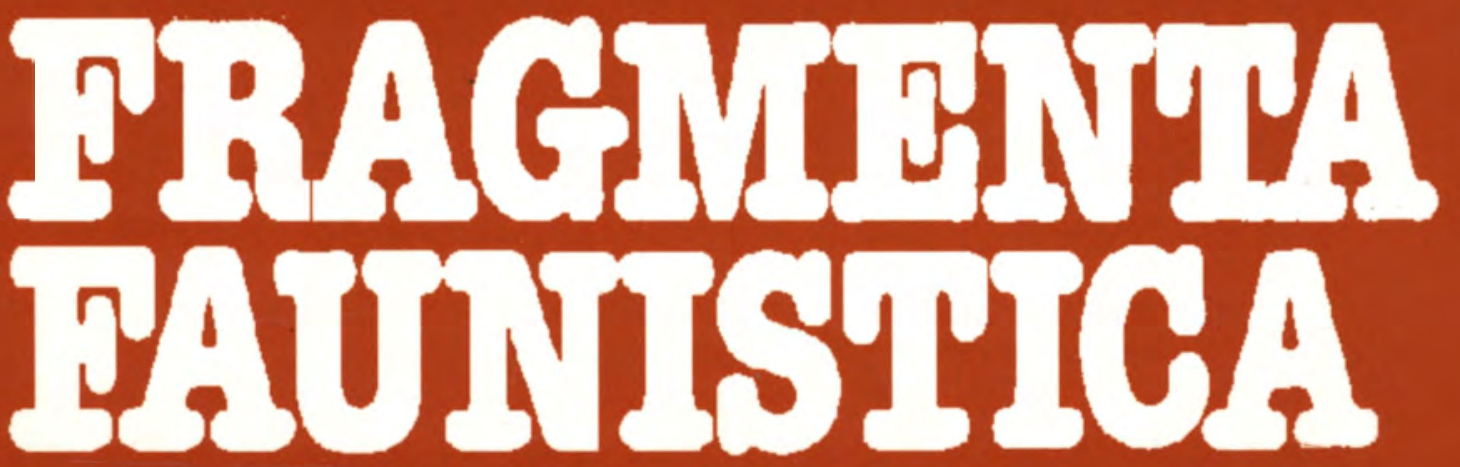

The succession of fauna

in the Bialowieża primeval pine forest

FOREST BIODIVERSITY PROTECTION PROGRAM GEF 05/21685 POL

Vol 37 No. 1 
FOREST BIODIVERSITY PROTECTION PROGRAM PROTECTION OF FOREST ECOSYSTEMS

GEF 05/21685 POL

\author{
Przemysław TROJAN
}

Regina BAŃKowska, Elżbieta CHUdZıcKA, Irmina PILIPIUK

Ewa SKIBIŃSKA, Maria STERZYŃSKA, Jolanta WYTWER

\title{
Secondary succession of fauna in the pine forests of Puszcza Białowieska
}

\author{
Edited by \\ PRZEMYSŁAW TROJAN
}


Elżbieta Chudzicka, Henryk Garbarczyk (zastępca redaktora naczelnego), Anna Liana, Waldemar Mikolajczyk, Regina Pisarska (redaktor naczelny), Maria Sterzyńska, Ewa Skibińska (sekretarz redakcji)

Adres Redakcji

Muzeum i Instytut Zoologii Polskiej Akademii Nauk 00-679 Warszawa, ul. Wilcza 64

(c) Copyright by Muzeum i Instytut Zoologii PAN

Warszawa 1994

ISBN 83-85192-37-9

ISSN 0015-9301

Nakład 650 egz. Papier kl. III 80 g.

Skład komputerowy, lamanie i diapozytywy - Dział Wydawnictw MilZ PAN

Druk - Drukarnia Nr 1, Warszawa, Rakowiecka 37 


\author{
Przemyslaw Trojan \\ Regina BAŃKOWSKA, Elżbieta CHUDZICKA, Irmina PILIPIUK \\ Ewa SKIBINSKKA, Maria STERZYŃSKA, Jolanta WYTWER
}

Secondary succession of fauna in the pine forests of Puszcza Bialowieska

\begin{abstract}
Multidirectional hypothesis of the secondary succession of fauna is considered. It contains five types of succession: creative, stabilising, rise-and-fall, regressive and restorative. The verification of these hypotheses during pine forest development is based on changes in the number of species. their abundance, the structure of the taxocoenes, actual and potential species diversity. 27 taxons (families or orders) with 1247 species occurring in Bialowieża primeval pine forest served as a material for comparisons. They represent all main trophic types of the fauna: phytophages, predators. parasites and saprophages among invertebrates, and also birds and mammals.

After the clear cutting of trees, no empty place appears with regard to fauna, which is the richest at this stage. The multidirectional character of the succession of fauna is predominant. Many indices decrease their values in the mature forest. Ecosystem stability is ensured by the better adapted forms while the potential diversity is not fully realised.
\end{abstract}

\title{
1. INTRODUCTION \\ 1.1. Study objectives
}

The formation of forest ecosystems takes a long time. Depending on the initial state of the environment, the process may follow one of two possible patterns. The first pattern is observed when a forest develops on a formerly unforested site, i.e. when a forest is formed in the area for the first time. Such a process is called primary succession. The other pattern is activated when the forest develops in areas which were previously occupied by a forest ecosystem, so that one may speak of forest reconstruction in that case. It is usually started by planting trees in a clearing formed after forest felling or a forest fire. This process is termed secondary succession.

An example of primary succession is the formation of forest ecosystems in dune areas as a result of the drainage of Lake Chicago and the formation of the shoreline of Lake Michigan in the postglacial period. This object represents a classic example of forest development from the stage of a sandy beach to a maple-beech forest. The sere also includes a pine forest stage (COWLES 1899. SHELFORD 1913). It has helped to construct a theory of ecological succession: 
the forming of this ecosystem took about 10.000 years: in the final stage, the vegetation cover attained considerable stability, while there are constant changes in the mineral cycling in the ecosystems (OLSON 1958).

European coniferous forests follow the other pattern - secondary succession. Cultivated, felled and afforested anew for hundreds of years, they become "ecologically mature" as soon as they reach the felling age. For the pine forest, the felling age is $80-150$ years. This time span determines the total length of the process of secondary succession because forest felling renders impossible further transformations of both the habitat and the biocenosis, and the ecosystem returns to the initial stage with new cultures being planted.

European and American ecologists usually consider the processes of forest succession from the viewpoint of the climax theory. The theory states that the settling of the former forest habitat is the dominant phenomenon in the first stage of succession. In the second stage, specific subsystems are formed within the biocenosis. In the final stage of succession, after the forest ecosystem has developed, the ecosystem is adapted to the habitat conditions in the area. such as climatic factors. The resulting final and stable stage of succession is called the climatic climax. In some cases, however, the final stage of succession depends on the fertility of the soil habitat, and is termed the edaphic climax.

The process of succession is accompanied by changes in biocenoses and habitat conditions. The direction of habitat transformations is not related to the habitat conditions occurring at the beginning of the process of succession. Most seres develop in a convergent manner, resulting in the same final stage. Under the circumstances of the Polish Lowlands, the final stage is represented by the Pino-Quercetum mixed forest (KoRNAŚ 1950, PAWLOWSKI 1959). Thanks to that, primary succession. no matter whether it starts in a shallowed pond, marsh, sand dune or limestone rocks, leads, after numerous ecosystem transformations, to the formation of a mixed forest.

The transformation of the vegetation cover in the course of forest succession is relatively well known (FALINSKI 1991). Much less is known about changes in the forest fauna during forest stand development. The data are incomplete. they concern different forests, dissimilar environmental conditions, various time spans and, usually, a small number of animal species. The situation is the same as regards studies of succession in European forests and forests in other continents.

Our understanding of faunal transformations in the course of succession is still much better than the theoretical background of succession processes (ANDERSON 1986). Theoretical assumptions are usually made on the basis of diverse premises, which are usually not sufficiently validated. An additional difficulty for a zoologist is the fact that most concepts of succession are concerned with plant associations, so that the findings, owing to specific traits of the botanical material. cannot be fully applied to faunal studies.

Because of that the theoretical mainstay for a zoologist is still the concept formulated by ODUM (1969). In its terms, the process of ecological succession is:

1. unidirectional and predicable, 
2. its pattern and rate are determined by the physical environment which also sets limits to development,

3. the process terminates in a stabilised ecosystem, where maximum biomass is present and functional links between organisms ensure control over the processes taking place and protection against disturbances.

The mechanisms of homoeostasis are supported by groups of organisms with similar functional characteristics but different ranges of ecological tolerance (TROJAN 1984). Depending on the internal arrangement of these systems (KIKKAWA 1986) they may be adapted to maintaining short-term or long-term stability,

Puszcza Białowieska is the greatest faunal refugium in the Central European Lowland as can be evidenced by comparing the animals occurring there to the fauna of the Central Polish Lowland. In the best known groups of animals in Puszcza Bialowieska, e.g. butterflies or Isopoda, the number of species recorded in the Puszcza well exceeds $80 \%$ of those known from the Central Polish Lowland (TROJAN unpublished data). The faunal richness of Puszcza Białowieska is the reason for the concentration of faunal research in the area. As a result, it is possible to analyze the phenomena occurring in the process of secondary succession of fauna. The number of over 30 taxons (orders or families) studied is a representative sample allowing to trace regularities in the process of formation of faunal complexes within the pine forest biocenoses of Puszcza Bialowieska. The material included in the present paper is not exhaustive if one considers the species richness of Puszcza Bialowieska, but it is the largest faunal sample that has ever been investigated at the same place and stage of the development of fauna of pine forests.

The data on the fauna of Puszcza Bialowieska are an irreplaceable source of comparative information. The primeval nature of the forests is much better preserved, and the number of felling cycles much smaller, than in all other European forests. As a result, the data on the fauna of that forest complex serve as a frame of reference for all faunal studies conducted in Polish forests as well as in other countries. The structure of the fauna of Puszcza Bialowieska may be used in an exemplary fashion when analysing changes occurring in faunal communities in forests situated in other areas.

Objectives of the study. The following objectives were set for the analysis of the secondary succession of pine forest fauna:

1. Determination of the formula for pine forest zoocenosis structure, and classification of specific groups of animals into functional groups within the forest biocenosis.

2. Comparison of the species composition of the animal groups studied in the various succession stages and assessment of changes in the species composition of the fauna.

3. Estimation of the number of species in each animal group. Comparison of empirical and estimated data and assessment of the degree to which the material collected is representative.

4. Description of the structure of the taxons in each stage of the sere. 
5. Determination of actual and potential species diversity of the taxons in the course of succession.

6. Comparison of changes in the structure and diversity of each faunal complex in the course of secondary succession of the pine forests in Puszcza Białowieska.

7. Assessment of the degree of complexity of the zoocenosis in each stage of succession.

The entire analysis of the phenomena occurring in the fauna during pine forest development is based on the concept of functional groups within the biocenosis. The groups are links which form the subsystems of the biocenosis to make up the homoeostatic system (TROJAN 1984), within which the processes of abundance regulation in forest ecosystems occur.

\subsection{Review of literature}

The course of secondary succession and the underlying mechanisms have been attracting naturalists' attention since the turn of our century. Over the last 15 years, nearly 100 papers concerned with this subject have been mentioned in bibliographical registers. A considerable number of papers is concerned with the theory of succession (about 30 items). Reviews of papers dealing with the theory of succession can be found in ANDERSON (1986) and FALINSKA (1991). The development of the theory of succession coincides with ongoing reconsiderations of the concept of the ecosystem, undertaken both by holists and by reductionists. Holistic views have been reflected in papers by MARGALEF (1968), ODUM (1971) and WHITTAKER (1975) where the succession is believed to occur on ecosystem level. Their reductionist opponents, e.g. MACMAHON (1980), GraY et al. (1987) attach greater importance to population processes. According to them. succession results from the living strategy of species and their interactions with the environment and with one another.

Views on the theory of succession, related notions, characteristic features and mechanisms have been mentioned in many ecology textbooks (TROJAN 1975 , STUGREN 1976. Odum 1977, Collier, Cox et al. 1978). A number of papers are concerned with various aspects of this phenomenon, concentrating on issues of stability. diversity, bioenergetics as well as mechanisms and mathematical models of succession.

A recent trend has been to treat both concepts as complementary (TROJAN 1984) so that the properties studied when interpreting succession phenomena relate both to individuals of various species and to populations and communities. SHUGART (1984) and PRENTICE (1986) emphasize the hierarchical character of the theory of succession, according to which processes occurring on higher levels stem from processes taking place on lower levels of organisation of the ecological system.

The studies of succession in forest ecosystems are conducted on different levels of organisation of the ecological system, including both soil and vegetation and zoocenoses. The literature on succession in these ecosystems permits to make comparisons in various types of forest stand and to trace transformations 
of both vegetation fauna. The studies are based on the theory of edaphic climax. Data on secondary succession in the pine forests in Puszcza Białowieska contain the results of analyses of a number of seres. If the sere develops in an suitable habitat, the rate of succession is usually accelerated. Comparative analyses show that when a forest is grown in an unsuitable habitat, substitute associations emerge and natural succession is delayed.

The structure of faunal systems is a sensitive indicator of changes occurring in the environment. They are manifested as alterations in the species composition. structure and abundance of faunal communities. A comparative analysis of faunal communities carried out in stands of various age may be used for describing and interpreting the processes occurring in the succession in the ecosystem studied. It is usually conducted in spatial seres, but its results can be extrapolated temporally, which makes possible interpretation of changes occurring in the course of succession, while the time of field observation is considerably shortened. A regular cycle of secondary succession in the pine forests of Puszcza Białowieska is completed in 150 years.

The literature on the processes of secondary succession in the pine forests of Puszcza Białowieska is rather poor. The botanical aspects have been dealt with by FALINSKI $(1989,1991)$ and TOLKAĆ \& DANCEVIC (1974). Data on faunal succession in these ecosystems are provided in 11 items. With one exception. they are concerned with selected groups of insects. Literature on fauna is exhaustively listed in KARPIŃSKI and OKOLÓW (1969) and OKOLOW (1976, 1983. 1991).

\section{AREA OF STUDY}

Puszcza Bialowieska is situated in north-eastern Poland. The area is divided by the state border between Poland and Byelorussia. In its contemporary limits, Puszcza Bialowieska includes the remains of three forest complexes associated in the north with the forest of Puszcza Knyszyńska. Situated on the border between Poland, Lithuania, and the historical regions of Jaćwierz and Ruś Wolyńska, it was depopulated in the 13th century (WIĘcKo 1972) to remain uninhabited for about 300 years. Despite the pillage of their resources during World Wars I and II, the forests of Puszcza Bialowieska have completed fewer felling rotations than forests situated west of it. Particularly valuable and rich are the deciduous forests characteristic of the temperate climate zone in Europe and undergoing "complete series of secondary and recreative succession" (FALINSKI 1989). Taking into consideration the natural values of these forests, it was decided that they would be protected as a Biosphere Reserve.

Apart from the common linden-oak-hornbeam forests and alder forests, Puszcza Białowieska also houses pine forests represented by the ultimate forest associations of Pino-Quercetum and Peucedano-Pinetum (subcontinental pine forest) (FALINSKI 1988). The latter, representing the "fresh" pine forest association type, grow on podzolic soils. The majority of these forests are situated in the south-eastern part of Puszcza Bialowieska, in Hajnówka forest inspectorate. 
There are about 3739 ha of pine forests in Puszcza Białowieska, accounting for less than $7 \%$ of the total forest stand area. The patches of the pine forest are composed of pine (about $76 \%$ ) and spruce (15\%) with a small addition of birch $(7 \%)$ and scanty contributions from other tree species such as oak or aspen.

Studies of secondary succession of the fauna of the forests of Puszcza Białowieska were carried out in Hajnówka forest inspectorate, more specifically in Starzyna forest district. Three sites were chosen in divisions 538, 667 and 668. Three even-aged coniferous forest stands, several hectares each, were selected within each of the sites for the study. These included mature stands (timber stands: 100-110 years), pole wood, i.e. III age class stands (40-60 years), young stands (15-25 years) and cultures ( $3-7$ years).

In order to collect cambio- and xylophagous beetles, additional catches were carried out in divisions 494 C, 519 D and 539 C.

The location of study sites is shown on the map (Fig. 1).

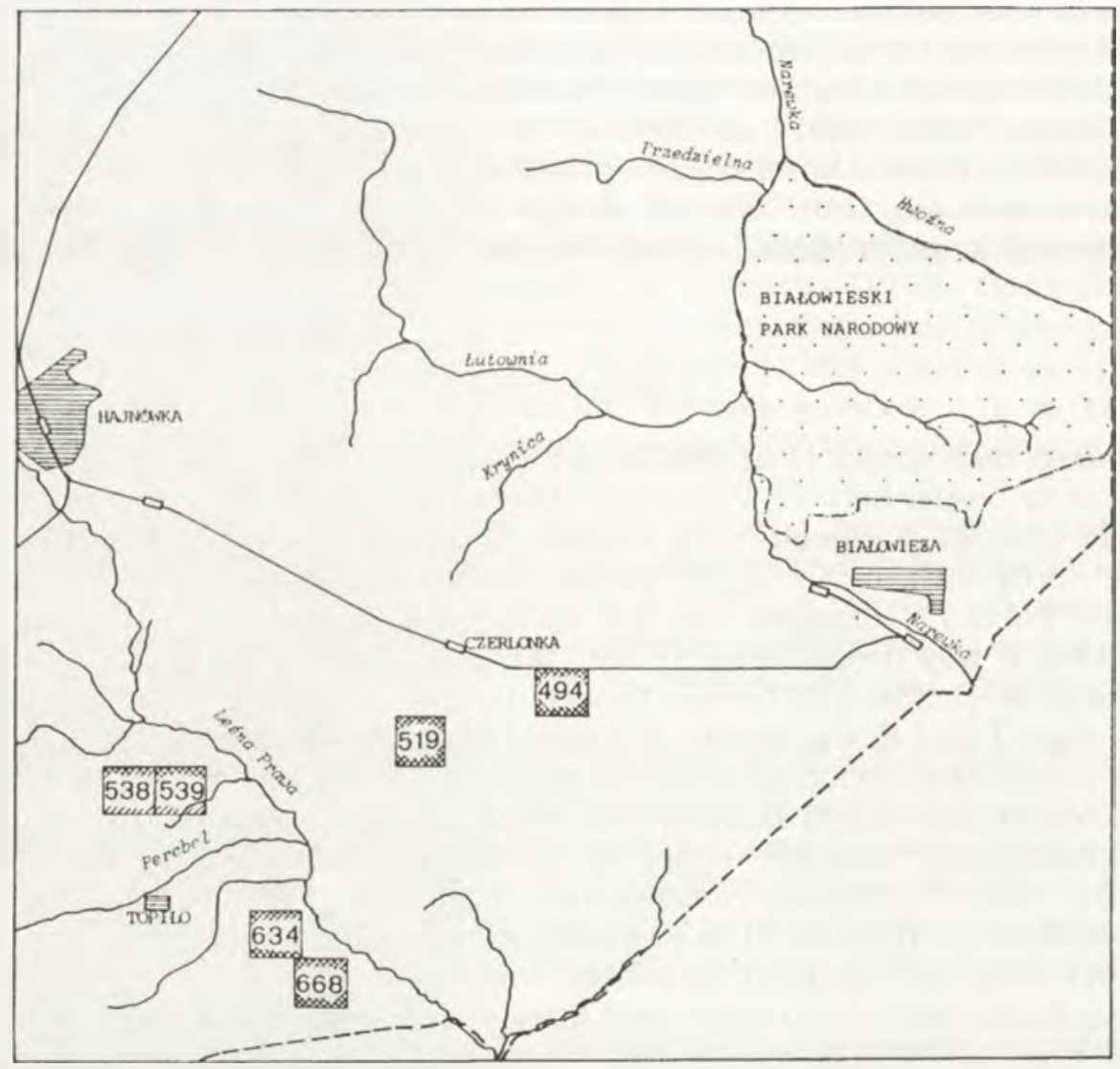

Fig. 1. Location of study stands in the pine forests of Puszcza Bialowieska 
Prior to collecting faunal materials, studies of plant associations (protocols) and soil analysis (soil profiles) were performed in the areas chosen for the study (MATUSZKIEWICZ et al. 1993).

As regards soil and phytosociology, all the areas included in the field study are homogeneous and represent the subboreal variety of the subcontinental (Peucedano-Pinetum) pine forest. The variety is characterised by a substantial contribution of spruce in the stand and understorey. The phytosociological analysis carried out in the stands revealed relatively insignificant differences in floristic composition between various age classes, even between stages as different as a mature forest and a clearing with young plantings. Unlike deciduous forests, the associations forming in the culture and young growth stage do not differ phytosociologically. The associations, however, are poorer in the number of species in comparison to a mature pine forest, at the same time comprising some species from sandy greens.

In terms of soil typology, in all the areas under study, the soils belong to the class of podzols and are characterised by acidic reaction and low acid-base sorption.

The study was carried out in patches of pine forest subject to normal silvicultural practices. The area undergoes clear felling with a cutting width of $60-80 \mathrm{~m}$. The restoration of the stand is accomplished by planting a culture in a specially prepared felling site composed of pine $(80 \%)$, spruce $(10 \%)$ and birch and oak $(10 \%)$.

\section{FAUNA SAMPLING METHODS AND MATERIAL}

The programme of studies encompassed 30 groups of invertebrates and 2 groups of vertebrates. They represent diverse life styles and a wide range of trophic and environmental relationships. Due to that, sampling methods were adjusted to the bionomic peculiarities of the various groups of animals. The methods can be divided into two groups: qualitative sampling techniques and standard quantitative methods.

The qualitative sampling techniques were designed specifically for the particular animal groups studied. They are described in separate papers concerned with individual taxons. The most common qualitative methods included "stalking" with a net, using decoys to attract insects and browsing through substrates associated with a particular faunal group.

The standard quantitative methods suited the vertical structure of the forest and activity patterns of the animals under study. Winged insects occurring in the canopy layer were collected using Moericke's pitfall traps (MOERICKE 1950) attached to top branches of trees by means of special pegs. The pegs enabled the containers to be hauled down at regular intervals in order to take out the specimens collected. Since the canopy layer starts to form only in grown up plantations, this sampling technique was used in pine stands of three age classes: young growth, pole wood (age class III) and mature forest. Three sampling sites were selected and 5 pitfall traps installed in each age class. 
resulting in a total of 45 traps. The specimens collected were taken out every fortnight, starting from the withdrawal of the snow cover until late November.

The material collected using this method in the years 1986-1987 contained more than 500,000 of arachnid and insect specimens (Tab. I). After the material had been sorted and species and their abundance determined by experts in the respective taxonomic groups, it was subjected to analyses described below.

Table I. List of materials collected using Moericke's pitfall traps in the pine forests of Puszcza Bialowieska in the years 1986-87

\begin{tabular}{|c|c|c|c|c|c|c|}
\hline \multirow{2}{*}{ Taxon } & \multicolumn{3}{|c|}{ Numbers of specimens } & \multirow{2}{*}{ Total } & \multirow{2}{*}{ Average } & \multirow{2}{*}{$\%$} \\
\hline & yung stands & pole wood & mature stands & & & \\
\hline Psocoptera & 451 & 695 & 566 & 1712 & 0.11 & 0.32 \\
\hline Blattodea & 97 & 32 & 10 & 139 & 0.01 & 0.03 \\
\hline Thysanoptera & 48582 & 83437 & 131262 & 263281 & 16.89 & 49.84 \\
\hline Homoptera & 2871 & 5333 & 3998 & 12202 & 0.78 & 2.30 \\
\hline Heteroptera & 265 & 660 & 1243 & 2168 & 0.14 & 0.41 \\
\hline Coleoptera & 3629 & 2767 & 2281 & 8677 & 0.56 & 1.65 \\
\hline Neuroptera & 1060 & 548 & 794 & 2402 & 0.15 & 0.44 \\
\hline Lepidoptera & 1308 & 890 & 889 & 3087 & 0.20 & 0.59 \\
\hline Hymenoptera: & & & & & & 0.00 \\
\hline Aculeata & 3660 & 1028 & 1244 & 5932 & 0.38 & 1.12 \\
\hline Parasitica & 10618 & 9384 & 80963 & 28965 & 1.86 & 5.49 \\
\hline Symphyta & 615 & 581 & 653 & 1849 & 0.12 & 0.35 \\
\hline Diptera & & & & & & 0.00 \\
\hline Nematocera & 30026 & 29555 & 20726 & 80307 & 5.15 & 15.20 \\
\hline Brachycera & 63478 & 30581 & 20889 & 114948 & 7.38 & 21.78 \\
\hline Aranei & 113 & 689 & 672 & 2474 & 0.16 & 0.47 \\
\hline Total & 167773 & 166180 & 194190 & 528143 & 33.89 & 100.00 \\
\hline
\end{tabular}

In order to determine the species composition of the herb layer fauna, a sweeping net was used ( 10 samples of 25 sweeps each in each area).

To collect animals linked with tree stems and branches, such as Buprestidae, Cerambycidae or Scolytidae, stems and branches were scanned and foil window-traps were used.

Estimation of the species composition and abundance of epigeic animals was performed using the square plot methods ( 1 sq.m., 10 sq.m. and 100 sq.m.). This method was used mostly in the case of ant communities. Rodents were caught into jars and traps placed on the surface of soil.

Soil mesofauna was assessed in the spring and autumn peaks. A standard steel corer with an area of $20 \mathrm{sq}$. $\mathrm{cm}$. was used for obtaining samples. 10 samples were taken at each site in each period. Additional 25 samples were taken at three sites in mature forests in selected microhabitats represented by patches of bilberry, moss, fern, litter and heather. The samples were then extracted in Tullgren funnels. Special extraction methods were employed for nematodes (BRZESKI et al. 1976). The animals were then conserved in $4 \%$ formalin solution.

Enchytraeids were extracted in O'Connor's apparatus (O'CONNOR 1971). 


\section{METHODS FOR PROCESSING DATA}

The data collected, usually quantitative, fulfilled the criteria for application in statistical analysis. This allowed to study the structure of individual taxocoenes and determine their quantitative characteristics.

The formula for the structure of various communities is obtained on the basis of models of five distributions, which are most extensively used in faunal studies nowadays (TROJAN 1992). The following models of structure were used:

1. A geometric series wherein an assumption is made that environmental resources are used successively in an lth part by each species forming the community, in accordance with the following series:

$$
l, l(1-l),(1-l)^{2} \ldots l(1-l)^{\mathrm{S}-1}
$$

Thus, the anticipated abundance of individual species assumes values according to the formula:

$$
n_{i}=\eta N l(1-l)^{i-1}
$$

where 1 and $\eta$ - equation constants calculated from sample parameters

$N$ - the total number of individuals in the sample

$i \quad-$ the rank of species in order of diminishing abundance.

2. Broken stick distribution wherein it is assumed that environmental resources are utilised in a random manner by individual species forming the community; the anticipated share of the species in the community is determined from the formula:

$$
E\left(\frac{n_{j}}{N}\right)=\frac{1}{S} \sum_{j=1}^{j=1} \frac{1}{S+1-j}
$$

where $i \quad$ - the species' rank (from the least to the most abundant)

$n_{j}$ - the number of individuals in the sample belonging to the species of $\mathrm{j}$

$\mathrm{N} \quad-$ the total number of individuals in the sample

$\mathrm{S}-$ the number of species in the sample

3. A logarithmic series wherein the distribution of the number of species, according to abundance increasing discretely, assumes the form of a series:

$$
\alpha v, \frac{\alpha v^{2}}{2}, \frac{\alpha v^{3}}{3}, \ldots, \frac{\alpha v^{r}}{r}
$$

where $r \quad-$ is the highest abundance of individuals within the species, and the series parameters $\alpha$ and $v$ are calculated theoretically relative to the number of species $S$ and sample abundance $N$; 
4. A lognormal distribution based on the assumption that species abundances, corresponding to the amounts of environmental resources used, present a normal distribution, with the greatest number of moderately abundant species, and small numbers of rare and most abundant species; in a logarithmic scale of increasing classes of abundance, called "octaves". in which the number of species $\left(\mathrm{S}_{\mathrm{R}}\right)$ determined in accordance with the lognormal distribution equation, is defined by the function:

$$
S_{R}=S_{O} e^{-(\varepsilon R)^{2}}
$$

where $S_{0} \quad$ - number of species in a modal octave

$\varepsilon \quad$ - equation parameter obtained from empirical distribution

$R \quad$ - ordinal number of abundance class

5. A negative binomial distribution based on the assumption that the probability of catching a given number of individuals belonging to a particular species is very low, corresponding to Poisson's distribution with the $\lambda$ parameter: if a certain variability of this parameter is assumed, the anticipated shares of species in the sample represented by a given number of individuals $P(X=r)$, the following form is assumed for the negative binomial distribution:

$$
P(X=r)=\frac{\Gamma(v+r)}{r ! \Gamma(v)} p^{r} q^{r}
$$

where $v, p, q$ are distribution parameters determined from the sample;

The computation of distributions was carried out in accordance with descriptions contained in a paper by TROJAN (1992) using a computer programme of the Museum and Institute of Zoology PAS. When the results were similar to the models used, data on quantitative characteristics determining the structure of the model were utilised. The similarity of empirical to theoretical distributions was verified on the basis of the $\chi^{2}$ test.

Actual species diversity in individual communities was measured with Shannon and Weaver's diversity index:

$$
H^{\prime}=-\sum_{i=1}^{S} \frac{n^{i}}{N} \log _{2} \frac{n_{i}}{N}
$$

where $n_{i} \quad$ - the abundance of the ith species

$N \quad$ - abundance of a given community composed of a total number of $S$ species.

Potential species diversity of various communities is expressed as the border values of Shannon and Weaver's index (TROJAN 1994). Because of that, the degree of realisation of the potential, expressed as Pielou's index, assumes the form: 


$$
J=\frac{H^{\prime}}{\log _{2} S^{*}}
$$

where $S^{*} \quad-$ is the potential number of species in the habitat.

Assessment of similarity of species composition of individual communities was made according to the "percentage" modification of Søerensen's formula (SøERENSEN 1948):

$$
\text { So }=2 \frac{w}{a+b} 100 \%
$$

where $a$ and $b$ refer to the number of species in the communities compared and $w$ to the number of species common to both communities.

\section{ANALYSIS OF SECONDARY SUCCESSION OF THE PINE FORESTS OF PUSZCZA BIALOWIESKA}

\subsection{A model of the structure of pine forest zoocenosis and the course of secondary succession.}

Animal communities inhabiting forest ecosystems form functional systems characterised by close linkage between their components. Puszcza Bialowieska is the first natural forest in Poland, for which a model was constructed to determine the ecological structure of the eçosystem (KARPIŃSKI 1949). According to the model "the functional groups of the florotone and the zootone and forest habitats of certain types correlating with one another form a forest biocenosis of a specific type". Karpinski distinguished 5 functional groups in the zootone, each with a different role to fulfil in the life of the forest.

Nowadays the organisation of forest ecosystems is viewed as a hierarchical system comprising 4 types of structural units (TROJAN 1984).

1. The subsystem, which is characterised by a specific input substrate that supplies this system, and contributes to regulating the whole ecosystem. There are five subsystems within each ecosystem: the biotope, the producers, and three subsystems forming the zoocenosis (or zootone, according to Karpinski): 1) saprotrophs, 2) biotrophs, 3) macrotrophs.

2 . The trophic (food) chain is the basic organisational unit of the subsystem. Individual chains differ with regard to the type of food (input link) consumed and the manner in which the food is captured. (One host plant may give rise to several trophic chains of biotrophes). Each chain consists of links corresponding to trophic levels (LINDEMANN 1942).

3 . The competitive association (guild) encompasses species forming a single link of the trophic chain. The species inhabit identical or similar ecological niches, understood as common food resources utilised by the entire guild and a common group of predatory and parasitic species exploiting the guild. 
4. The population is an internal organisation unit of the guild based on competitive relations.

The structure of zoocenoses based on the above four types of units is reproducible and universal. This means that similar organisational structures are found both in forest ecosystems and in meadow or field ones, or even in urbicenoses. Differences between them concern the shares of individual organisational units in a particular ecosystem. The differences are recognised and defined and the degree of uniqueness is determined by comparative faunistical analyses.

The organisation of forest biocenoses exhibits a high degree of complexity (SZUJECKI 1980). It can be seen both in conditions imposed by forest stand development, its spatial structure, seasonal and diurnal rhythms of animals and relationships between individual components of the environment. Any attempt to systematise these relationships is faced with the need to make simplifications and to assume that certain factors are central to regulating the system organisation. In the present paper the central role is performed by the trophic factor. The structure presented is thus equivalent to the trophic organisation of the zoocenosis. The paratrophic factor is given minor importance. Owing to this, for example, parasitic insects have been classified after phytophages, in which their larvae develop. The parasites play an additional role as mellitophages, feeding on honey-dew and nectar and pollen of flowers, which are pollinated in this way. This system of feedback relations has not been reflected, however, in the above outline of the organisation of the pine forest zoocenosis of Puszcza Białowieska.

The pine forest zoocenosis, like other forest ecosystems of this climatic zone, is composed of three subsystems: biotrophic, saprotrophic and macrotrophic. The present paper gives most consideration to the biotrophic subsystem because of the character of the materials collected and analysed and the ability of domestic experts to analyze individual animal groups.

The biotrophic subsystem comprises two groups of trophic chains. The chains are initiated by first-level consumers (C1) i.e. chewing phytophages and sucking phytophages (Fig. 2). Particularly important is the chewing phytophage link. which comprises lepidopterans (Lepidoptera) and sawflies (Symphyta) - the most dangerous pine foliophages which periodically invade some regions of Poland causing severe damage to pine stands. Similar functions are also fulfilled by weevils (Curculionidae) and leaf beetles (Chrysomelidae). Only the former pose a significant threat to forests as pests of pine. The next group of phytophages is composed of species sucking leaves and young sprouts. It includes aphids represented by the specialised family of Lachnidae associated with coniferous trees. Parallel chains are formed by homopterans (Homoptera. Auchenorrhyncha) and heteropteran bugs (Heteroptera). This group may be defined as phytophages undermining the forest stand by sucking substantial amounts of assimilates out of leaves and sprouts. A particular role in forest ecosystems is played by xylophages and cambiophages. This group occurs characteristically in forest ecosystems. In the present study, it is represented by three beetle families: 


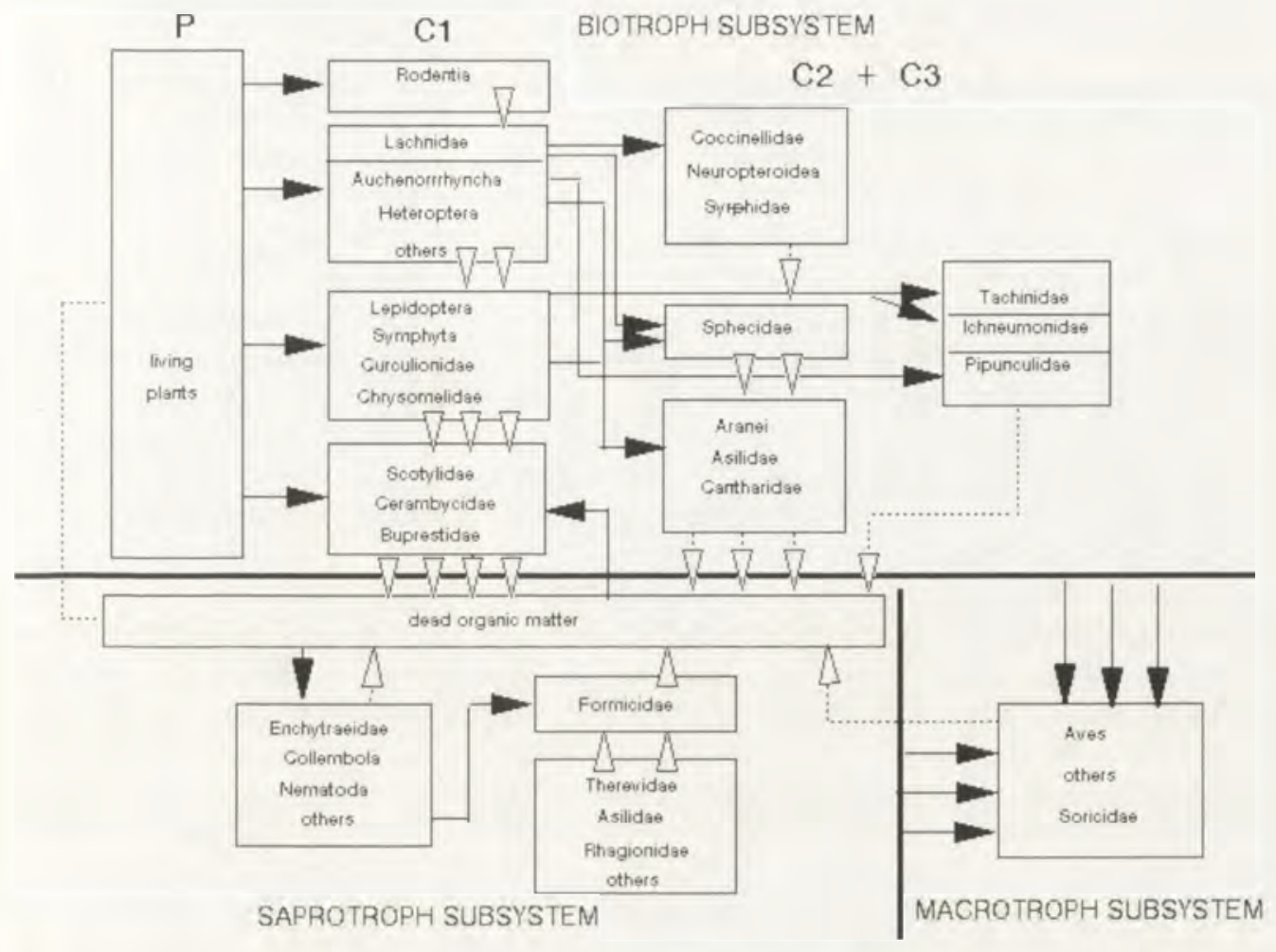

Fig. 2, Zoocenosis organisation in the pine forests of Puszcza Bialowieska

buprestids (Buprestidae), cerambycids (Cerambycidae) and bark beetles (Scolytidae).

Zoophages include parasitic and predatory forms specifically associated with certain groups of phytophages. In this paper special attention is given to distinguishing parasitoids that reduce the abundance of foliophages, i.e. tachinid flies (Tachinidae) and ichneumon flies (Ichneumonidae). Groups of species reducing the abundance of sucking phytophages, i.e. predatory aphidophages and parasites of Homopterans, are also well represented. All these animal groups are second-level consumers (C2). Two subsequent links are formed by predatory forms (C3) hunting in flight or on the surface of plants and soil robber-flies (Asilidae) and digger wasps (Sphecidae)) as well as spiders (Aranei) hunting in their webs.

The saprotrophic subsystem in the pine forest is well-developed both as regards detritophages, polyphages and zoophages. Not all of the groups of soil fauna can be analysed at present with accuracy required for faunal studies. The relationships occurring in animal communities of this subsystem have been described on the basis of model animal groups such as nematodes (Nematoda). 
enchytraeids (Enchytraeidae) and springtails (Collembola). Polyphages are represented by ants (Formicidae), which are most effective in controlling forest ecosystems. Therevidae served as an example of soil predators.

The macrotrophic subsystem, which controls both the biotrophic and the saprotrophic subsystems, is represented by birds and small mammals.

Ecological succession is one of the more important processes occurring in ecosystems. It is a reflection of dynamic processes that take place in every ecosystem. The studies of the forests of Puszcza Białowieska have provided a basis for the development of the dynamic concept of vegetation cover (PACZOSKI 1951). The idea has also been developed by KARPIŃSKI (1949), who distinguished fluctuation and succession processes. He also drew attention to the relative stability of climax systems bustling with continuous processes of change, which are, however, not directional. These concepts have recently been developed by FALINSKI (1989), also on the basis of Puszcza Bialowieska. Falinski distinguished three types of processes occurring in ecosystems: directional, fluctuating and cyclical. Of the three types, only the directional processes of succession and regression are important from the viewpoint of the present analysis. The separation of the two processes is, however, difficult. The task is all the more complicated because regression processes, like succession processes, consist of multiple stages and result in the system adapting to the altered environmental conditions. Particularly unclear is the problem of finding measures for the progress resulting from succession. FALINSKI (1989: 105) lists among such measures "a conventional dynamies index", the state of the biomass, energetic relations between the components, etc. All of these measures are incremental so that non-growth processes are not regarded as elements of the notion of succession, In zoocenology, such a reasoning has an implicit assumption of growth of the biomass, diversity, abundance and the number of species. Such a course of succession is, however, very poorly evidenced for.

In the present paper, the assumption is made that succession (primary as well as secondary) leads to relative stability of the system. The stability is expressed, among other things, by the fact that the growth processes in the system are slowed down or stopped, and the entire energy gain is utilised in internal regulatory processes, i.e.

$$
\begin{gathered}
\mathrm{B} \approx \text { const }, \\
\Delta \mathrm{B}=\mathrm{R}
\end{gathered}
$$

where B - biomass and R - respiration. All regulatory processes are thus accomplished at the expense of energy, which, in the ecosystem's final account, is used to compensate for the costs of maintenance and activity, i.e. the metabolism of the components forming the biocenosis.

It is not easy to resolve the issues in question on theoretical grounds. The nature of material collected for the purpose of the study still permits verification of the views on secondary succession by determining which of the 5 variants of succession presented below (Fig. 3) is actually observed in the course of development of the pine forest of Puszcza Bialowieska. 
a) creative succession

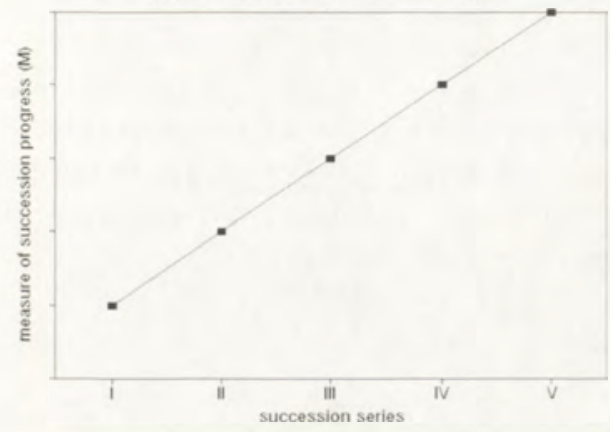

c) rise- and-fall succession

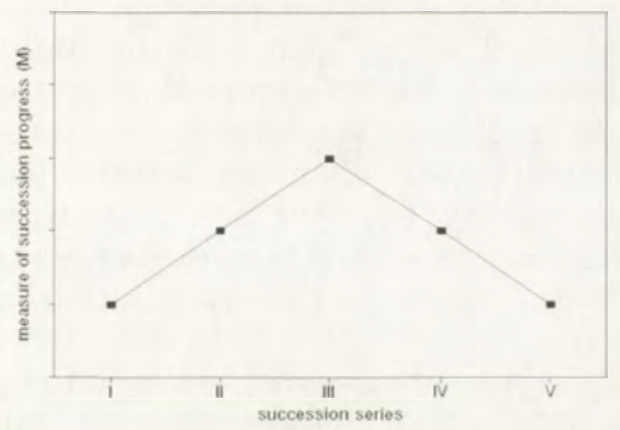

e) restorative succession

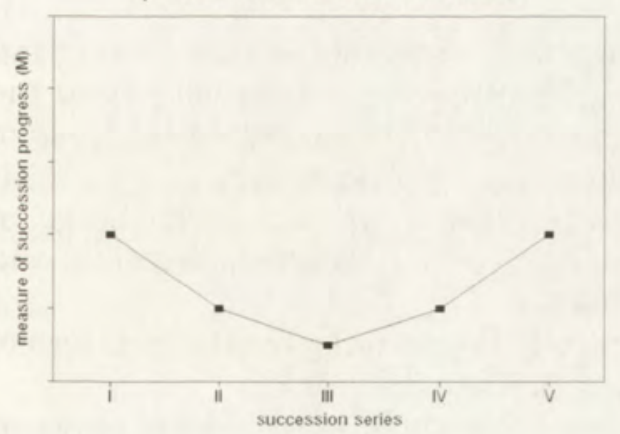

b) stabilising succession

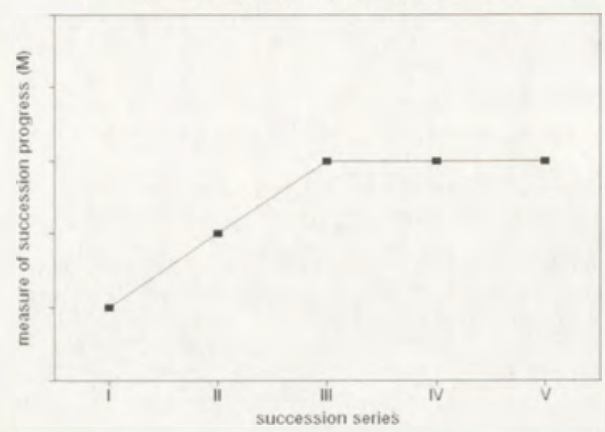

d) regressive succession

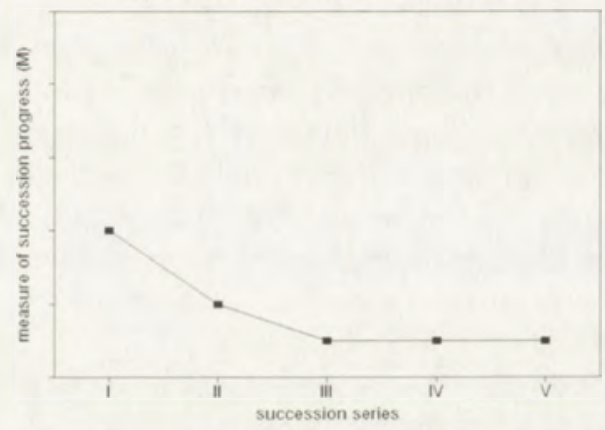

Fig. 3. Variants of the course of secondary succession 
Creative succession (a) is observed when the measure of succession progress of a community in the consecutive stages of the sere is higher than the preceding one

$$
\mathrm{M}_{0}<\mathrm{M}_{1}<\mathrm{M}_{2} \ldots<\mathrm{M}_{\mathrm{n}}
$$

The system where such a series of values is registered develops infinitely.

Stabilising succession (b) is seen when the measure of succession progress increases in the initial period to subsequently stabilise, irrespective of development or growth processes observed in other components

$$
\mathrm{M}_{0}<\mathrm{M}_{1}<\mathrm{M}_{2}=\mathrm{M}_{3} \ldots=\mathrm{M}_{\mathrm{n}}
$$

Rise-and-fall succession (c) is characterised by an initial increase in the measure of succession progress followed by a fall

$$
\mathrm{M}_{0}<\mathrm{M}_{1}<\mathrm{M}_{2} \ldots<\mathrm{M}_{\max }>\ldots \mathrm{M}_{\mathrm{n}-2}>\mathrm{M}_{\mathrm{n}-1}>\mathrm{M}_{\mathrm{n}}
$$

Such a series of values will be characteristic of those communities within zoocenoses which contribute to the development of the system in the initial stages of the sere. They are often pioneer species or pioneer groups that set the stage for groups better adapted to living in an organised biocenosis.

Regressive succession (d) is observed in situations when a group reaches maximum values in the first stage of succession where the system is least organised. The increase in the degree of organisation of the biocenosis results in a gradual reduction of the function of this group and its elimination or substantial decline.

Restorative succession (e) is an attribute of communities which survived fairly well the catastrophe connected with the destruction of the ecosystem, but witness a decrease in the measure of succession progress in the first stages. The value increases only after the target level of ecosystem organisation is attained.

A number of simple measures of the progress of succession may be used in assessing the progress of succession of a given taxon representing either a certain faunal complex or a certain guild:

1. Abundance, when assessed with comparable methods; it may be referred to area or volume; or be relative in character, expressing animal activity or the action of a hunting tool. Abundance is a measure of the ecological success of the taxon studied - if it increases, or a regression - if it decreases.

2. The number of species inhabiting the ecosystem in a given stage of succession reflects community development or recession. Both empirical (S) and estimated (S*) number of species may be used.

3. Actual $\left(\mathrm{H}^{\circ}\right)$ and potential $(\mathrm{H} \max )$ species diversity indicates the richness of a given taxocoene and the degree to which it fills the habitat.

4. The index of dominance determining quantitative relationships between species forming a guild. Interpretation of the value of this index is not clear. especially when a sere is concerned. 


\subsection{Succession in the subsystem of biotrophs}

\subsubsection{Phytophages}

As regards the mode of feeding and the quality of the food they take in. phytophagous insects may be divided into three biotic groups. The first group is composed of ecotrophs or chewing phytophages, which feed on the green parts of plants. The second group is that of endotrophs with a stinging-sucking mouth apparatus designed to absorb substances produced by plants without damaging the assimilating apparatus. The third group comprises xylophages and cambiophages trophically associated with woody plants. Chewing phytophages include caterpillars of butterflies (Lepidoptera), larvae of sawflies (Hymenoptera, Symphyta) as well as numerous families of beetles, such as leaf beetles (Chrysomelidae) or weevils (Curculionidae). Sucking phytophages embrace, above all else, hymenopterans such as aphids (Aphidoidea) and leafhoppers (Auchenorrhyncha) together with phytophagous heteropteran bugs (Heteroptera).

Another important phytophagous group in forest ecosystems is formed of xylophages and cambiophages biologically associated with trees.

\section{Sucking phytophages}

7 species of aphids of the family Lachnidae, 23 species of leafhoppers and 39 species of phytophagous Heteroptera (KOLODZIEJAK in press, CHUDZICKA unpublished data. CMOLUCHOWA, LECHOWSKI 1993) were recorded in the canopies of pine forest stands in Puszcza Białowieska in all the forest stand age classes studied (young growth. pole wood, mature forest). In each of the above groups. a similar number of species was registered in every age class of the forest stand, with the greatest number of aphid species recorded in the pole wood, and of leafhoppers and heteropteran bugs, in mature stands (Fig. 4).

The species composition of all the communities of sucking phytophages collected in canopies of pine was similar (Søerensen's similarity indices ranked from $62 \%$ to $99 \%$ ). The highest similarity of species composition was recorded for communities of aphids; in each age class of the forest stands these communities were solely composed of monophages feeding on one or a number of pine species. Similarity indices of species composition of aphid communities occurring in canopies of pines in the stands studied in Puszcza Bialowieska ranged between $80 \%-99 \%$.

It should be added that the species composition of each of the chewing phytophage communities studied in the canopies of trees in the pine forests of Puszcza Białowieska was considerably similar to the species composition of communities inhabiting eanopies (So) of pines in other Polish forest complexes (KOLODZIEJAK in press, CHUDZICKA unpublished data, CMOLUCHOWA, LECHOWSKI 1993).

In the pine forest sere changes in abundance and dominance structure occur in all the communities of sucking phytophages under study. In aphid and leafhopper communities the indices of relative abundance decrease with the 


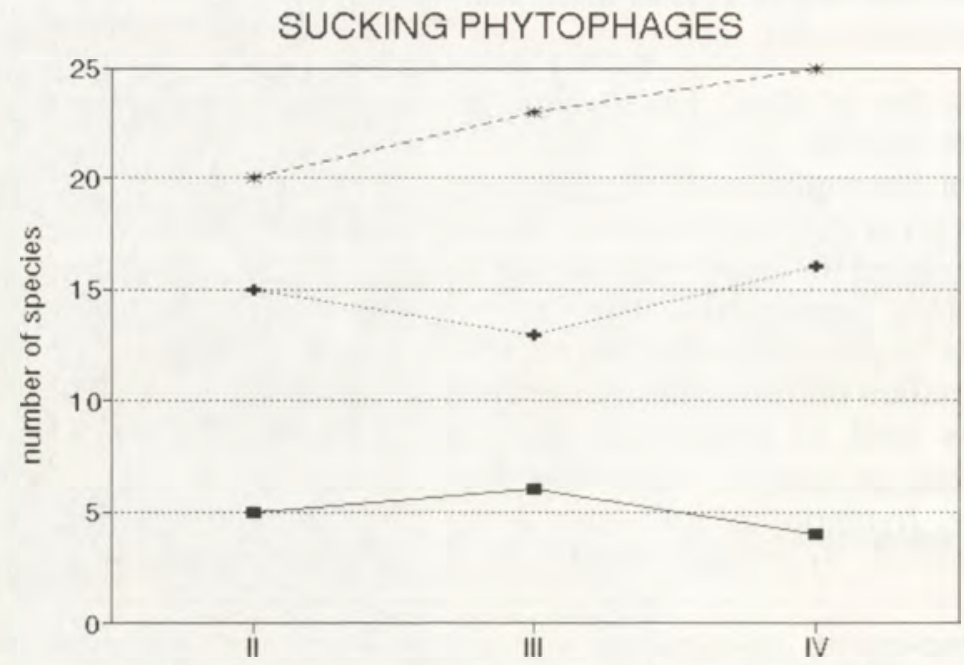

\section{- - Lachnidae —- Auchenorrhyncha - *- Heteroptera}

Fig. 4. Changes in the number of species of sucking phytophages in pine forests (3 age classes of the forest stand)

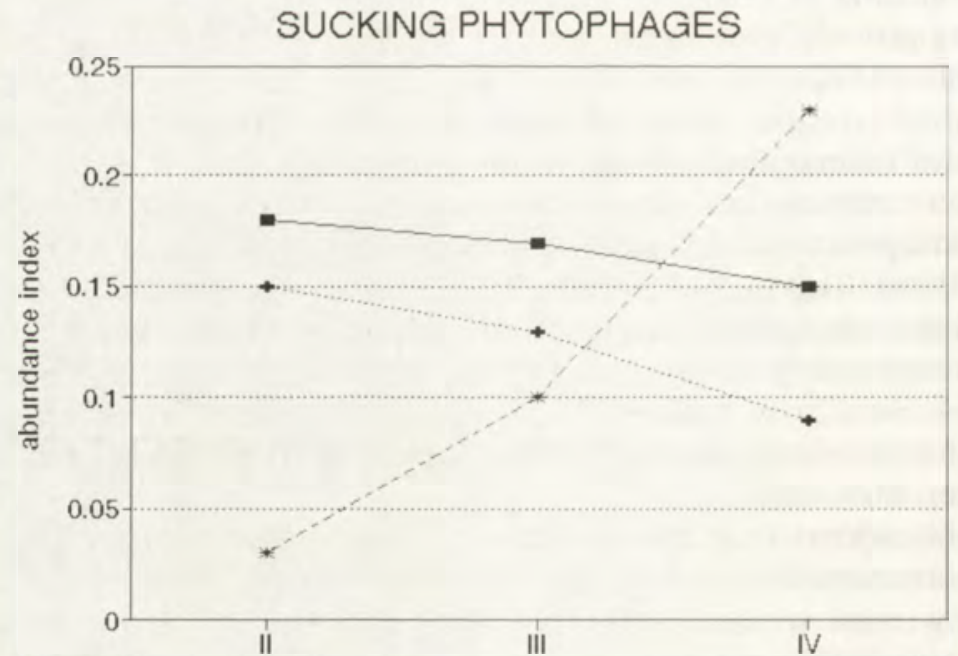

Fig. 5. Changes in the abundance of sucking phytophages in pine forests ( 3 age classes of the forest stand) 
growing age of the stand, while communities of phytophagous heteropteran bugs exhibit the reverse (Fig. 5).

Changes in the structure of dominance of the phytophagous insect communities under study consisted predominantly in shifts of positions, or ranks, of the dominant species. On the other hand, differences in the composition of the dominant species group were not observed in any community studied (Fig. 6-8).

A significant transformation of the dominance structure in communities of aphids took place between the young growth and pole wood stages. Compared to the young growth community, the pole wood community is characterised by a diminished rank of Schizolachnus pineti, a species which forms compact colonies on tops of sprouts and feeds predominantly on young needles. On the other hand, there is an increase in the proportion of Eulachnus agilis, a species which does not form colonies and feeds on 2-3-year-old needles of pine (Fig. 6).

In the leafhopper communities studied in the sere, there is an increase in the rank of two pine monophages, namely Wagneripteryx germari and Grypotes puncticollis. On the other hand there was a reduction in both abundance and proportion of Speudotettix subfusculus, a polytope settling in various forest habitats (Fig. 7). In the leafhopper communities, a considerable transformation of the dominance structure occurred between the pole wood and mature stages.

In the case of heteropteran bugs, changes in the structure of dominance occurring in the sere consisted predominantly in an increase of the proportion of Plesiodema pinetellum, a monophage of pine, in older stands. The species

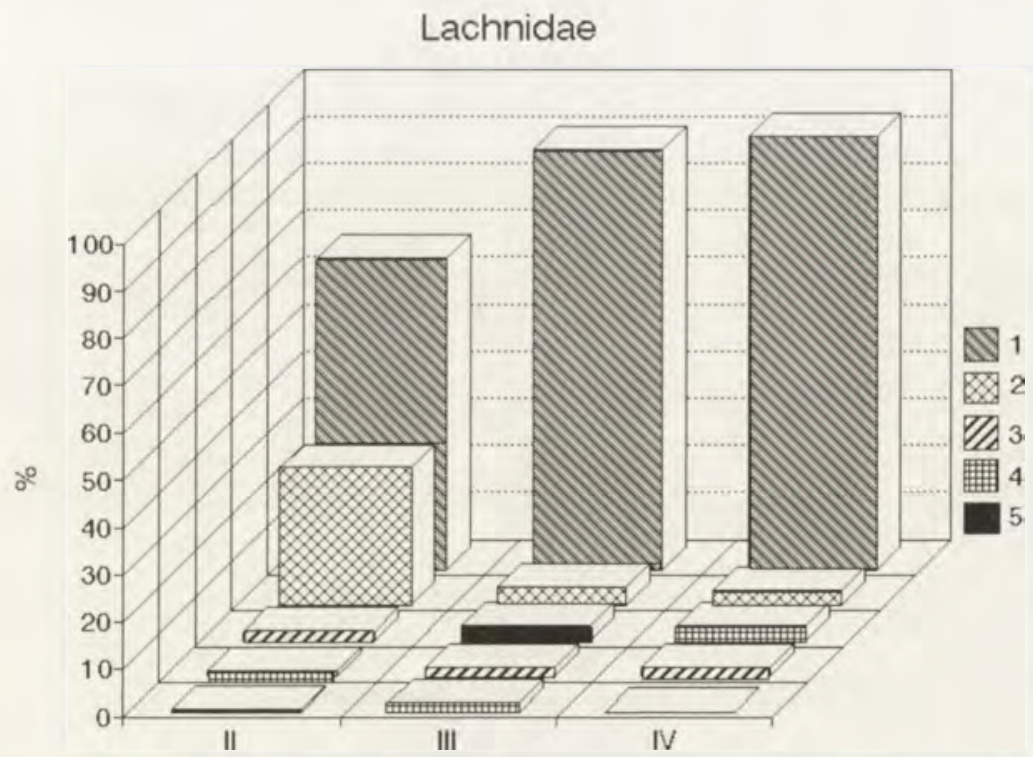

Fig. 6. Dominance structure of communities of aphids (Aphidoidea, Lachnidae) in canopies of pine in forest stands of various ages in Puszcza Białowieska; 1 -Eulachnus agilis, 2 - Schizolachnus pineti. 3 - Cinara pinea, 4 - C. pilosa, 5 - C. pini 


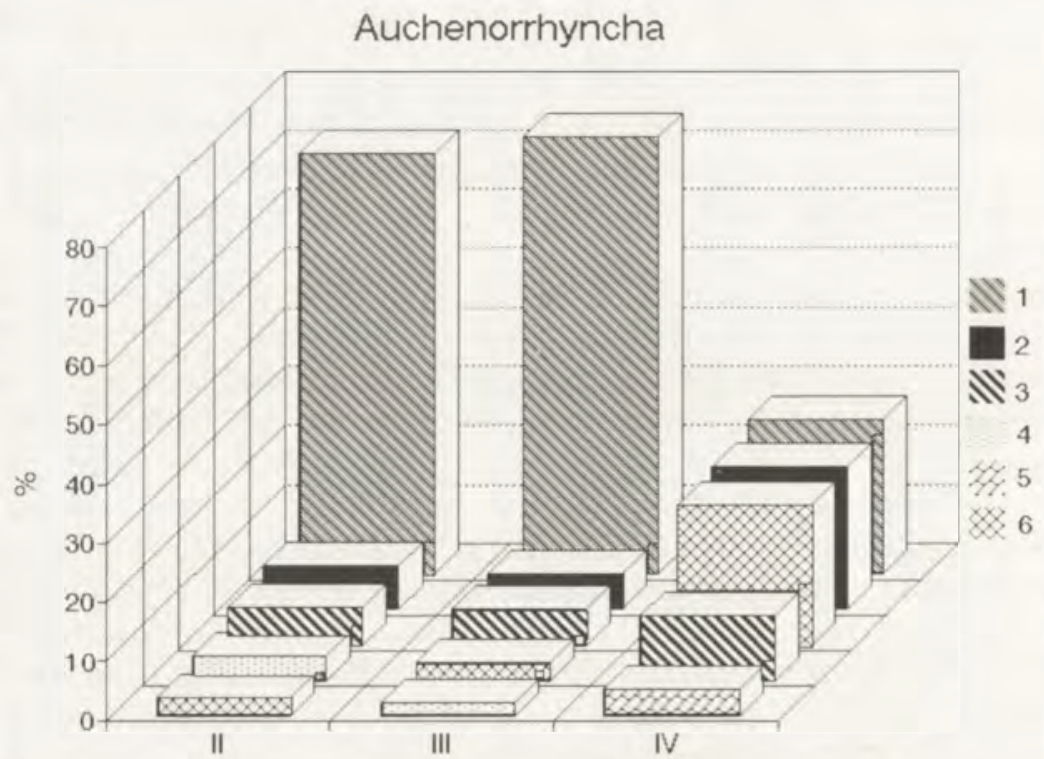

Fig. 7. Dominance structure of communities of cicadas (Homoptera. Auchenorrhyncha) in canopies of pine in forest stands of various ages in Puszcza Białowieska; 1 - Speudotettix subfusculus, 2 Wagneripteryx germari, 3 - Oncopsis flavicollis, 4 -Hesium domino, 5 -Grypotes puncticollis, 6 Allygus mixtus

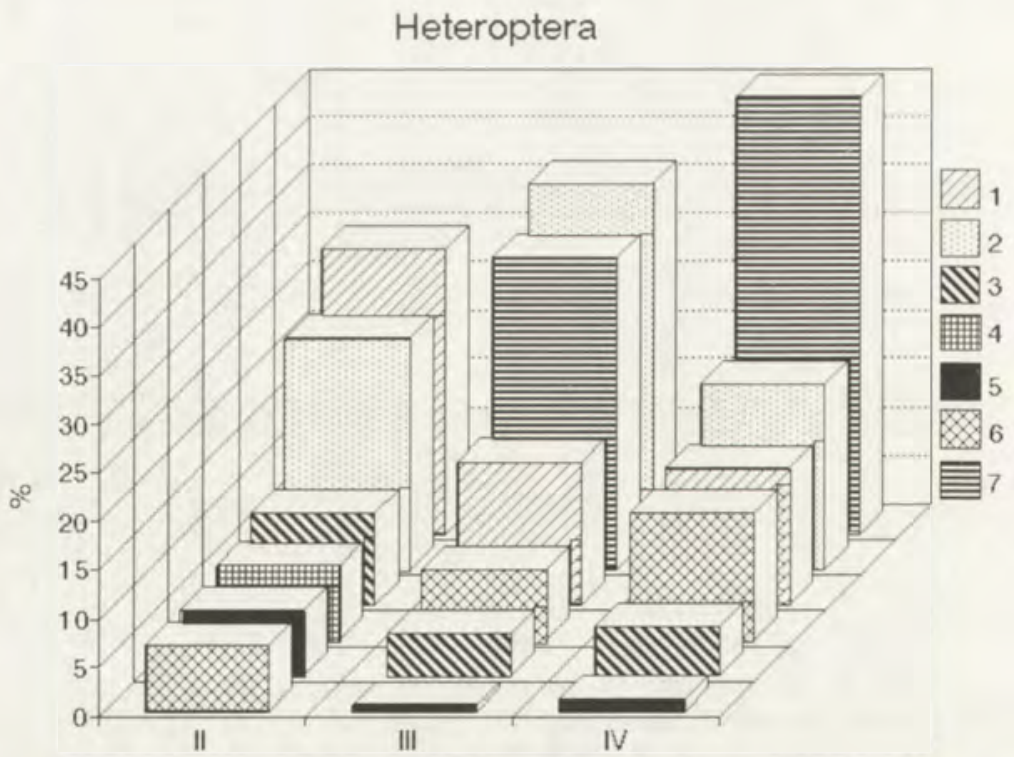

Fig. 8. Dominance structure of communities of heteropterans (Heteroptera) in canopies of pine in forest stands of various ages in Puszcza Białowieska; 1 - Phytocoris intricatus, 2 - Phoenicocoris obscurellus, 3 - Camptozygum aequale, 4 -Phytocoris intricatus, 5 - Alloetomus germanicus, 6 Phoenicocoris modestus, 7 - Plesiodema pinetellum 
attained peak abundance and proportion in the mature forests of Puszcza Białowieska (Fig. 8). Its abundance in pole wood was nearly four times lower, and in young stands, a hundred times lower, than in mature stands. Moreover, in older stands a decrease was observed in the proportion of two species not so narrowly specialised as monophages, namely Phytocoris intricatus and $P$. pini. both of which are trophically associated with various coniferous tree species.
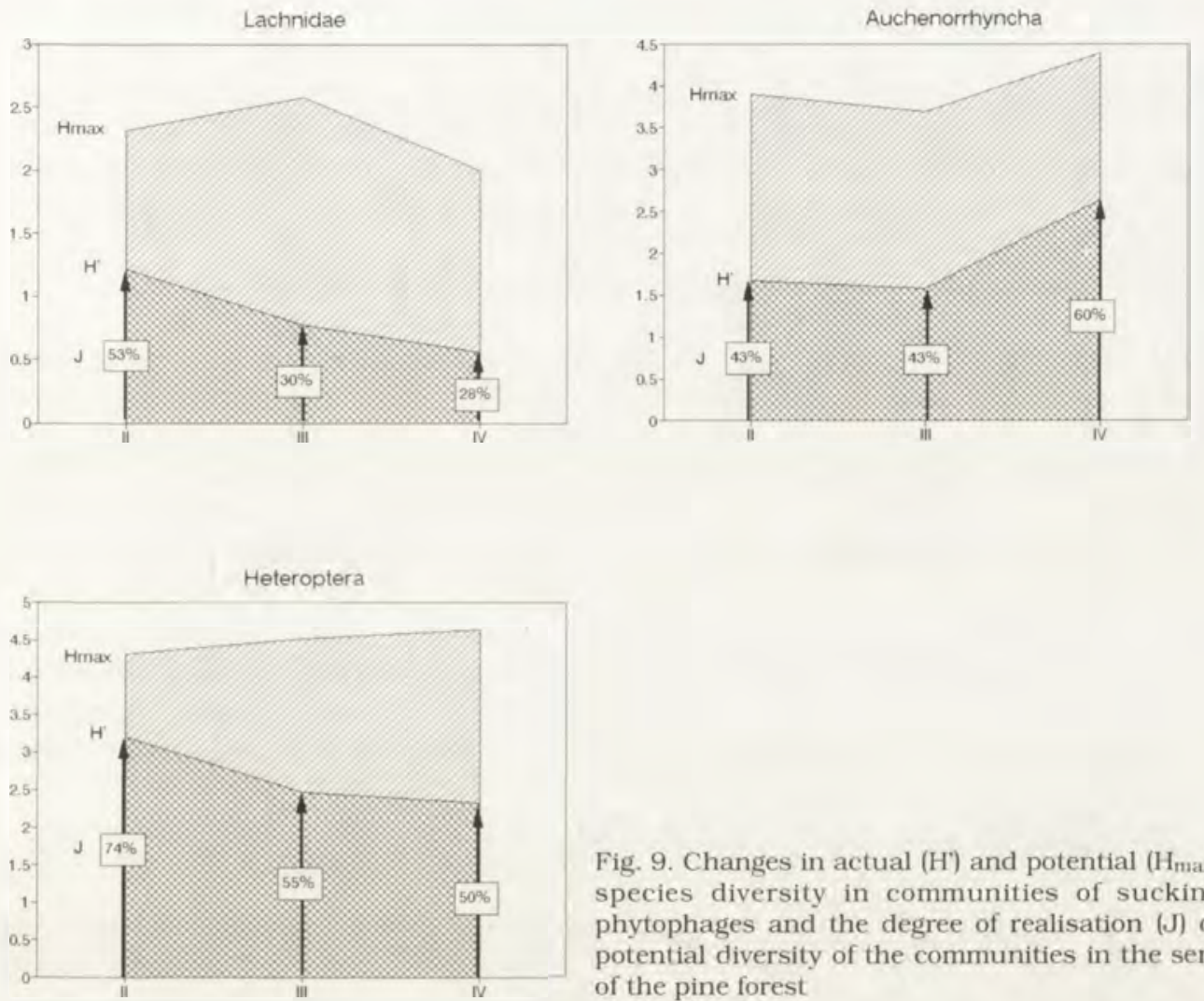

Fig. 9. Changes in actual $\left(\mathrm{H}^{\mathrm{r}}\right)$ and potential $\left(\mathrm{H}_{\max }\right)$ species diversity in communities of sucking phytophages and the degree of realisation $(\mathrm{J})$ of potential diversity of the communities in the sere of the pine forest

The similarity of species composition in all the sucking phytophage communities occurring in stands of all age classes in Puszcza Białowieska, as well as the differences in abundance and community structure described above substantially affected species diversity measured with Shannon and Weaver's index (Fig. 9). In the sere under investigation, species diversity of both aphid and heteropteran communities decreased with greater species diversity differences noted in both communities between young growth and older stands (pole wood, mature forest) that between the latter two. Cicadas exhibited a different response to the process of succession, reflected in an increase in species diversity with the growing age of the forest stand. In that case the mature forest is a stage of greater potential species diversity than the younger stages: young stand and the pole wood. In the pine forest sere studied in Puszcza Białowieska, 
the degree to which species diversity approximated the potential of the faunal system varied from community to community. In aphid and heteropteran communities, the degree of realisation of diversity (measured with Pielou's index) is highest in young stands, while in the case of leafhoppers the highest values were registered in mature stands (Fig. 9). As the forest stand grows older, differences are also noted in the distribution of individual species' shares in their communities. Decreases in the degree of uniformity of individual species distribution were recorded in aphid and heteropteran communities, while increases in species proportions' uniformity with the growing age of the stand were seen in communities of leafhoppers.

Analysis of structures of the communities of sucking phytophages showed that they do not fit any of the five distribution models formed so far i.e. the geometric series, broken stick distribution model, logarithmic series, lognormal distribution and negative binomial distribution.

The process of formation of the unique sucking phytophage fauna of the canopies of trees in pine forests starts in young stands (or possibly even earlier, in the culture stage), as is indicated by the remarkably high similarity of species composition of communities occurring in different age classes of the pine forests of Puszcza Białowieska. The transition between consecutive succession stages of the pine forest is marked by changes (although their rate and direction differ from group to group) in abundance and dominance structure of all the sucking phytophage communities studied. Generally, as the forest stand grows older, both the abundance and proportions of species associated with pine tend to increase, while the abundance and proportion of poly- and oligotrophic species are reduced. The formation of a dominance structure characteristic of pine canopies is nearly completed in 50-year-old forest stands (aphids, heteropteran bugs). In leafhoppers the process is slower, concluding in stands older than 50 years.

\section{Chewing phytophages}

115 species of sawflies (Hymenoptera, Symphyta), 23 species of leaf beetles (Coleoptera, Chrysomelidae) 46 species of weevils (Coleoptera, Curculionidae) and 122 species of butterflies (Lepidoptera) (HUFLEJT unpublished data, WASOWSKA unpublished data, WIŚNIEWSKA unpublished data, BUSZKO and WINIARSKA unpublished data) were recorded in the canopies of pine forest stands in Puszcza Białowieska in all the forest stand age classes studied (young stand, pole wood, mature forest). In the majority of the groups of chewing phytophages under study, the number of species forming the communities tended to decrease as the forest stand grew older. The reason for the decrease in the number of species was the same for all communities. In younger stands (particularly in young stands). there was a significant number of species associated trophically, often only in the larval stage, with plants occurring in the ground cover of the pine forest studied in Puszcza Białowieska: 30 such species were recorded in the community of sawflies in young stands, 26 in the pole wood and 20 in mature stands. The respective figures for the Curculionid community were 12 species 
in young stands, 6 in the pole wood and 7 in mature stands. On the other hand, the number of species of butterflies grows steadily as the stand develops with 70 species recorded in young stands, 91 in the pole wood and 100 in mature stands (Fig. 10).

\section{CHEWING PHYTOPHAGES}

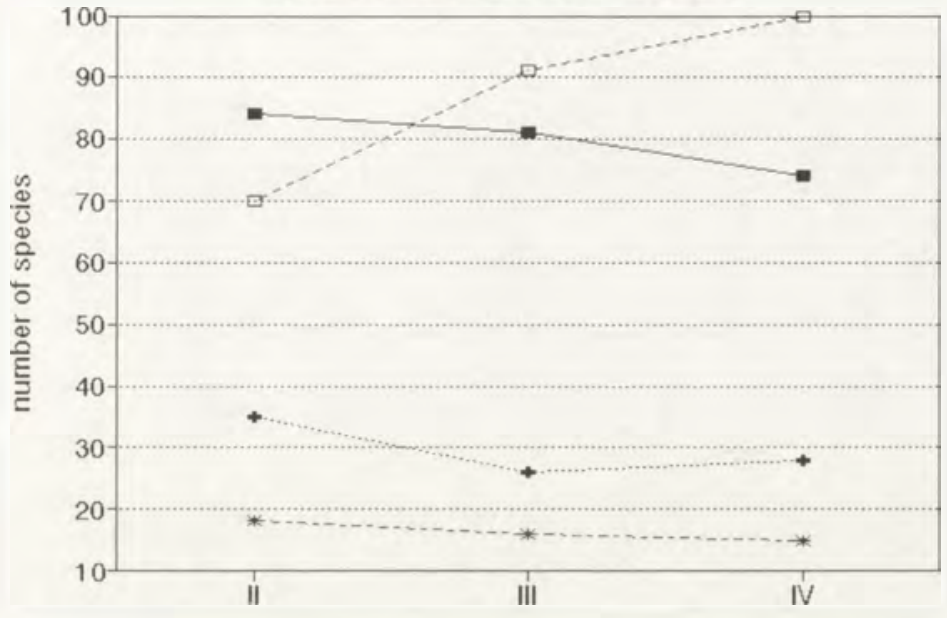

Symphyta

- Curculionida

Chrysomelid - E- Lepidoptera

Fig. 10. Changes in the number of species of chewing phytophages in pine forests of three age classes of the forest stand

The species composition was similar in all the communities of biting phytophages studied. The highest similarity of species composition was recorded for communities of butterflies and sawflies with Søerensen's similarity indices ranged from $68 \%$ to $79 \%$ for individual communities, while the lowest values were obtained for communities of Chrysomelidae $(47 \%-58 \%)$. The values of similarity indices (So) of individual communities inhabiting canopies of pines were largely dependent on local differences in the species composition of the ground cover and the understorey vegetation. It was particularly evident in the case of insect species of high trophic specificity. For example, Hypera nigrirostris (Curculionidae), a species feeding on clover, was registered in young and mature stands (in the latter it was even a dominant species), but did not occur in the pole wood. Of three species associated with cruciferous plants and recorded in young stands, only one was found in the pole wood and none in the mature forest. In leaf beetle communities, virtually all the species caught in canopies of trees in the pine forests feed on leaves of either herbaceous plants or deciduous trees (only 1 out of 27 species found in Puszcza Białowieska feeds on pine). As a result, the species composition of communities of beetles of this family was 
much more dependent on local species richness of the ground cover and on the presence of various tree species and deciduous shrubs in the understorey.

Communities found in older stands (pole wood, mature forest) exhibited conspicuous similarity both in species composition (similarity indices ranged from $58 \%$ for leaf beetle communities to $77 \%$ for sawflies) and the structure of dominance of individual communities.

On the other hand, abundance of the sawfly, leaf beetle and weevil communities studied did not exhibit significant differences related to the age of the stand (Fig. 11).

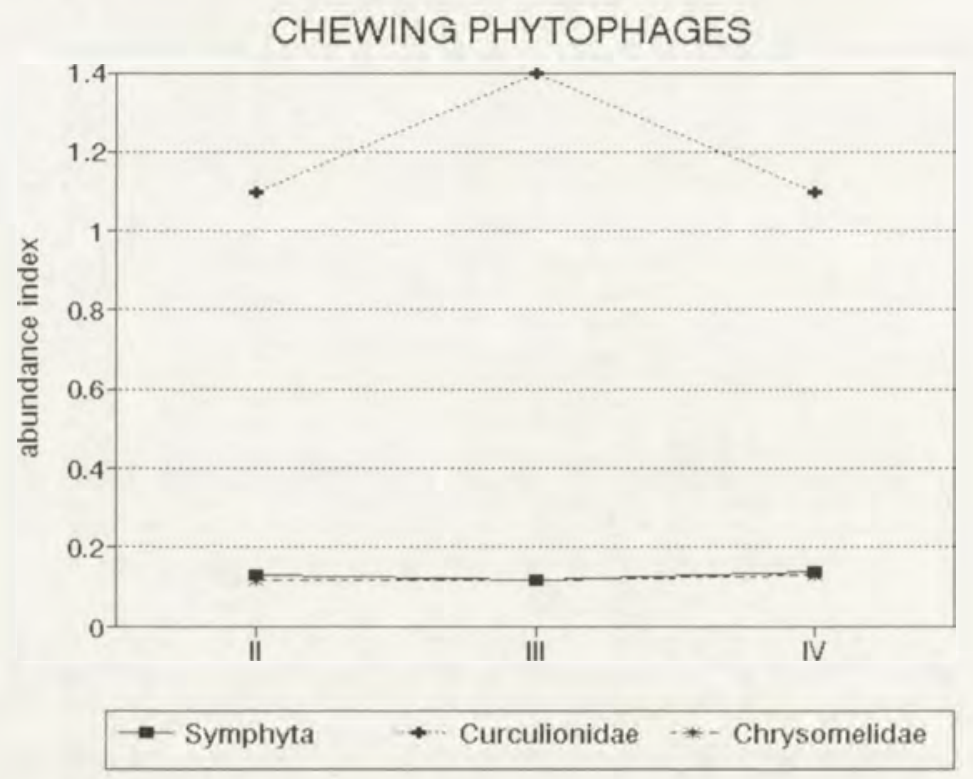

Fig. 11. Changes in the abundance of chewing phytophages in pine forests of three age classes of the forest stand

In the sere studied changes in dominance structure occurred in all the communities of chewing phytophages under study. They consisted predominantly in shifts in the rank of the dominant species.

In sawfly communities, the proportion of the monophage of pine Xyela julii (larvae feed on male efflorescence) rose with the growing age of the stand (from $2 \%$ in young stands to $16 \%$ in mature stands), while the reverse phenomenon was observed for Athalia rosae (from 33\% in young stands to about $10 \%$ in mature forests). A. rosae is a very common species occurring in various habitats (Fig. 12). The proportion of Pristiphora abietina, the larvae of which feed on needles of spruce, remained fairly constant in all the age classes of the forest stand.

A significant transformation of the dominance structure in communities of beetles of the family Curculionidae could be seen between the young growth and 


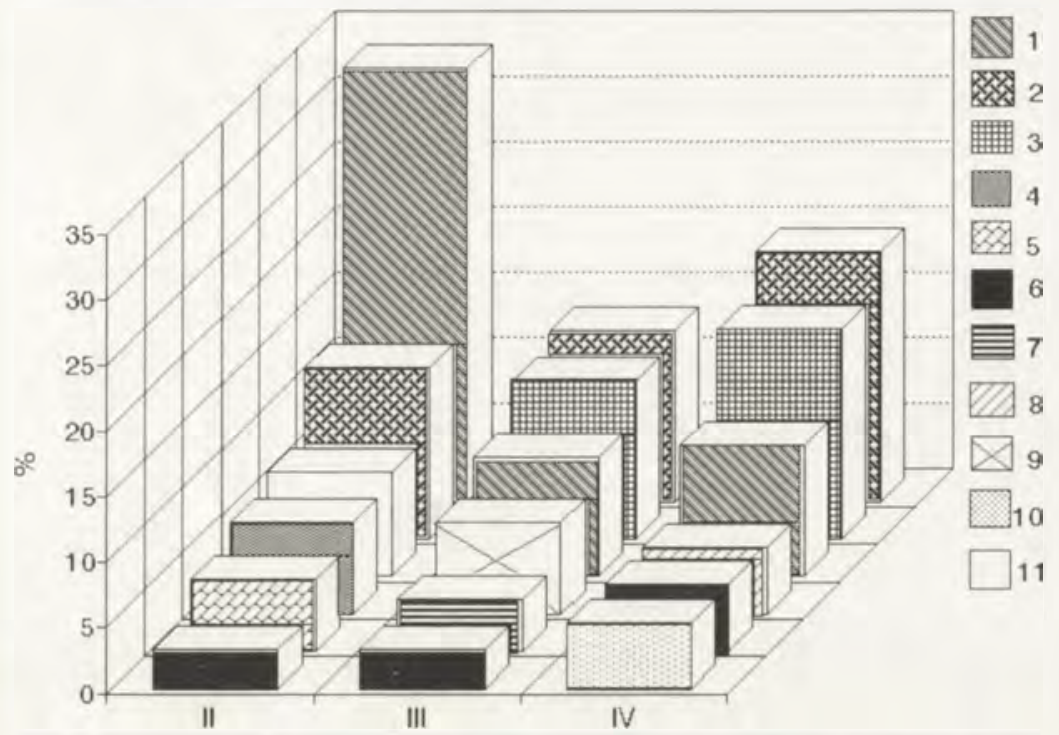

Fig. 12. Dominance structure of communities of sawflies (Hymenoptera, Symphyta) in canopies of pine in forest stands of various ages in Puszcza Białowieska; 1 - Athalia rosae, 2 -Pristiphora abietina. 3 -Xyela julii, 4 - Rhogogaster picta, 5 -Athalia bicolor, 6 -Pristiphora pseudodecipiens, 7 - Nematus dispar, 8 - Dineura viridorsata, 9 - Shaliphora parva, 10 - Fenusa pusilla, 11 - Athalia circularis

\section{Curculionidae}

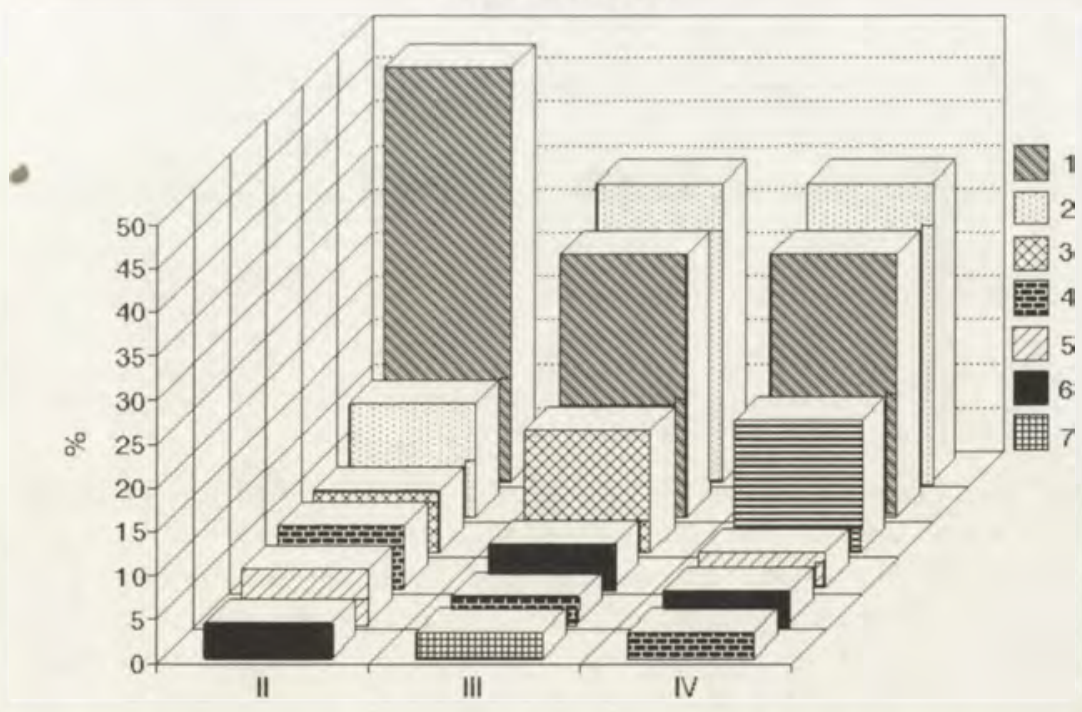

Fig. 13. Dominance structure of communities of xxx (Coleoptera, Curculionidae) in canopies of pine in forest stands of various ages in Puszcza Białowieska; 1 - Brachonyx pineti, 2 - Rhinomacer attelaboides, 3 - Anthonomus phyllocola, 4-Attelabus nitens, 5 -Magdalis linearis, 6 - Straphosoma capitatum, 7 - Daydrhynchus austriacus, 8 - Hypera nigrirostris 
pole wood stages. It consisted in a decrease in the rank of Brachonyx pineti, a species feeding on pine needles, for the benefit of Rhinomacer attelaboides, which develops in male efflorescence of coniferous trees. In young stands, B. pineti was the eudominant with a proportion of $47.4 \%$, and was followed by $R$. attelaboides (13\%) (Fig. 13). In older stands (pole wood, mature stands) both species were co-dominant.

In the Chrysomelidae beetle communities the proportion of Galerucella lineola increased as the stand grew older. The imagines of this species feed on deciduous trees and shrubs. On the other hand, there was a reduction in the share of Aphtona euphorbiae, a species associated with the ground cover vegetation (Fig. 14).

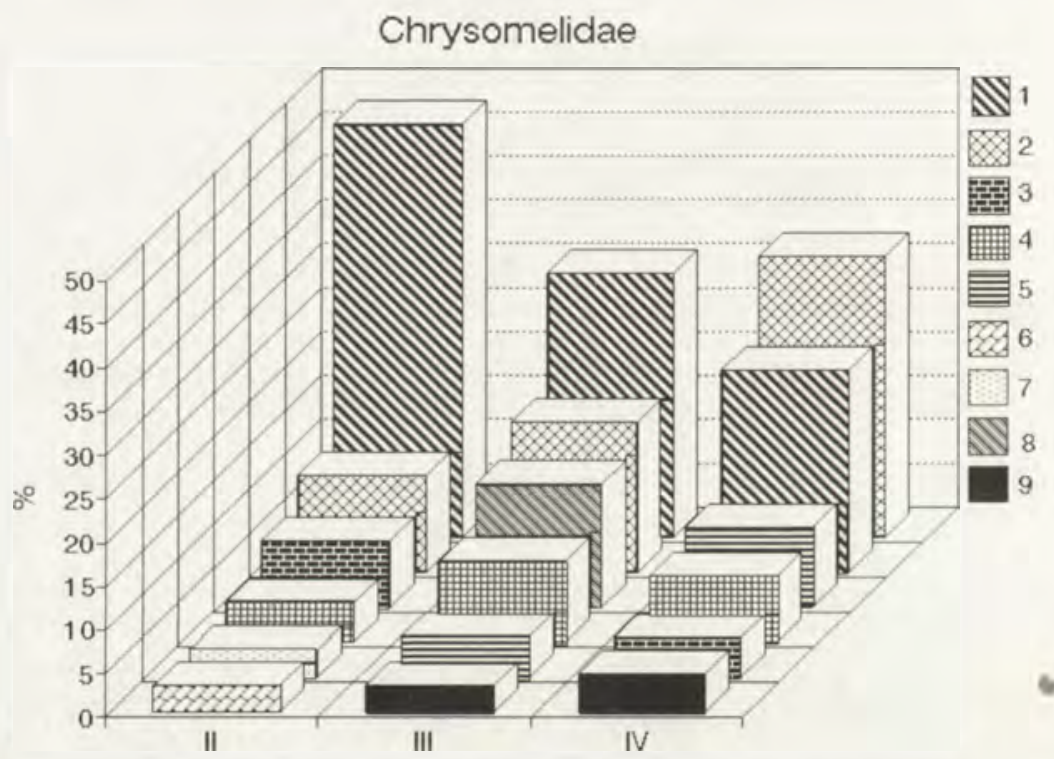

Fig. 14. Dominance structure of communities of leaf beetles (Coleoptera, Chrysomelidae) in canopies of pine in forest stands of various ages in Puszcza Bialowieska; 1 -Aphtona euphorbiae, 2 - Galerucella lineola. 3 -Longitarsus parvulus, 4 -Cryptocephalus parvulus, 5 - Cryptocephalus flavipes, 6 Longitarsus longiseta, 7 -Phyllotreta nemorum, 8 -Phratora laticollis, 9 -Cryptocephalus saliceti.

In Lepidoptera communities the pine monophage, Olethreutes bifasciana is the dominant species in all succession stages. There is also a high proportion of species associated with the ground cover or even deciduous trees (Rhopobota naevana, Apotomis betuletana, Alcis repandata). A. betuletana is only found in mature stands, while $R$. naevana and $A$. repandata belong to the dominant group in all age classes. Characteristic is an extremely low proportion of species recognised as primary pine foliophages (Lymantria monacha and Bupalus piniarius).

The values of Shannon and Weaver's index corresponding to total species diversity of individual communities of chewing phytophages display relatively 
insignificant differences in relation to the age of the stand (Fig. 15). Despite the small differences, the highest species diversity in all the communities of chewing phytophages was recorded in younger stands: young stands (Curculionidae) or the pole wood (Symphyta, Chrysomelidae)

In the sere of the pine forest of Puszcza Białowieska potential species diversity (measured with Pielou's index) ranged from $72-82 \%$ for sawfly communities, and $76-85 \%$ for leaf beetle communities. Somewhat lower values of potential species diversity were obtained for Curculionidae communities, but even in this case, the values of Pielou's index were similar in all stand age classes (Fig. 15).
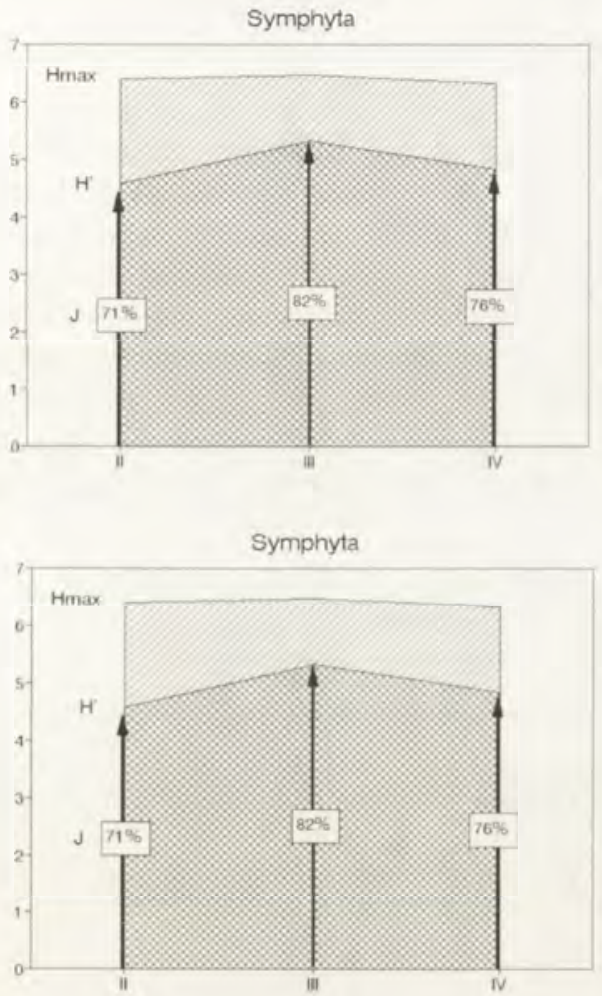

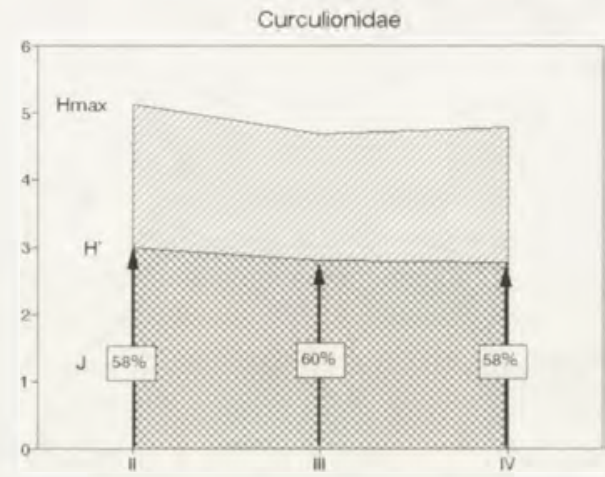

Fig. 15. Changes in actual $\left(\mathrm{H}^{2}\right)$ and potential $\left(\mathrm{H}_{\max }\right)$ species diversity in communities of chewing phytophages and the degree of realisation $(\mathrm{J})$ of potential diversity of the communities in the sere of the pine forest

Analysis of structures of the communities of chewing phytophages showed that they do not fit any of the five models of abundance distribution among individual species i.e. the geometric series broken stick distributionseries, logarithmic, lognormal distribution and negative binomial distribution.

The process of formation of the chewing phytophage fauna specific to the pine forests of Puszcza Białowieska takes place in the pole wood stage, as is indicated by the considerable similarity of species composition and dominance structures in communities occurring in the pole wood and mature stands.

In all the chewing phytophagesr communities studied transitions between consecutive stages of the pine forest sere are marked by changes in abundance 
and dominance structure. The changes in the dominance structure consist predominantly in shifts in the position, or rank, of species predominating in a given community. In weevil and sawfly communities older stands witness an increase in the proportions of species whose larvae feed on male efflorescence of pine: in the leaf beetles community there is a decrease in the proportion of the species feeding on deciduous tree leaves. As the stand grows older, a decrease is observed in the number of species trophically associated (often only in the larval stage) with herbaceous plants that only penetrate canopies of pines. This holds true both for many species of sawflies, the majority of adult forms of which are mellitophagous, and many species of beetles, which are phytophagous both in the larval and adult stages.

\section{Xylophages and cambiophages}

The consecutive stages of the pine forest sere create different conditions for the development of xylophages and cambiophages, which develop in or under the bark, or in the wood of various species of trees and shrubs. Individual species of these beetles are associated with specific plant species, inhabiting different layers from roots, stems, branches to thin twigs. They also settle in decaying stumps, damaged during forest felling and clearance, and in wood remaining after the felling. Various species of these insects show preference for certain phases of bark decomposition. Injuries to the foot of a tree, which weaken the entire organism, increase in severity as the stand grows, promoting the development of xylo- and cambiophages.

\section{XYLO- and CAMBIOPHAGES}

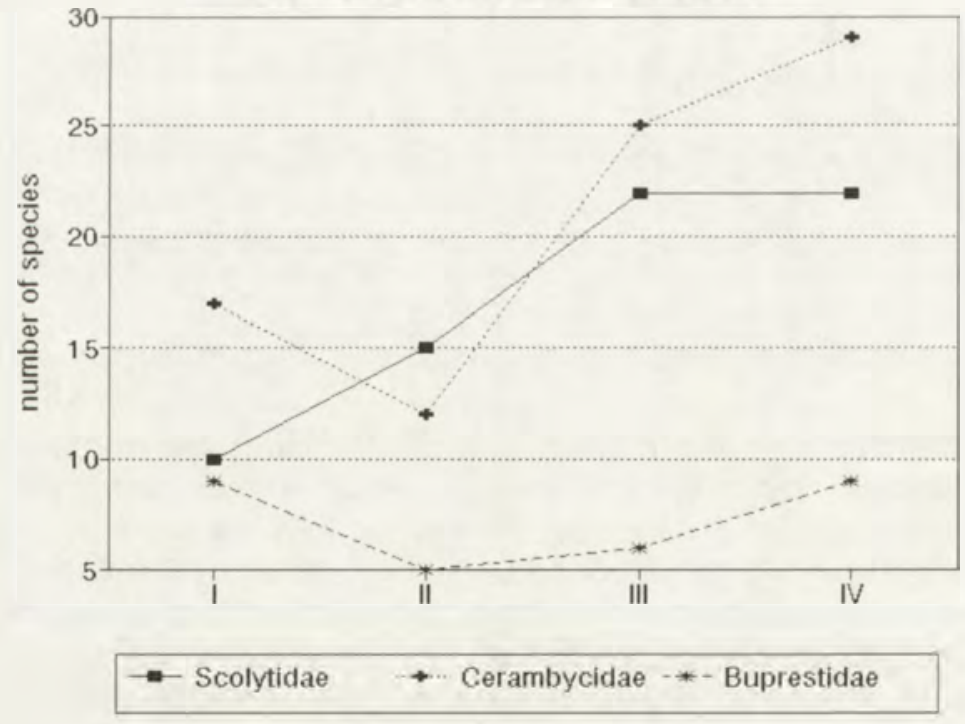

Fig. 16. Changes in the number of species of xylophages and cambiophages in pine forests of three age classes of the forest stand 


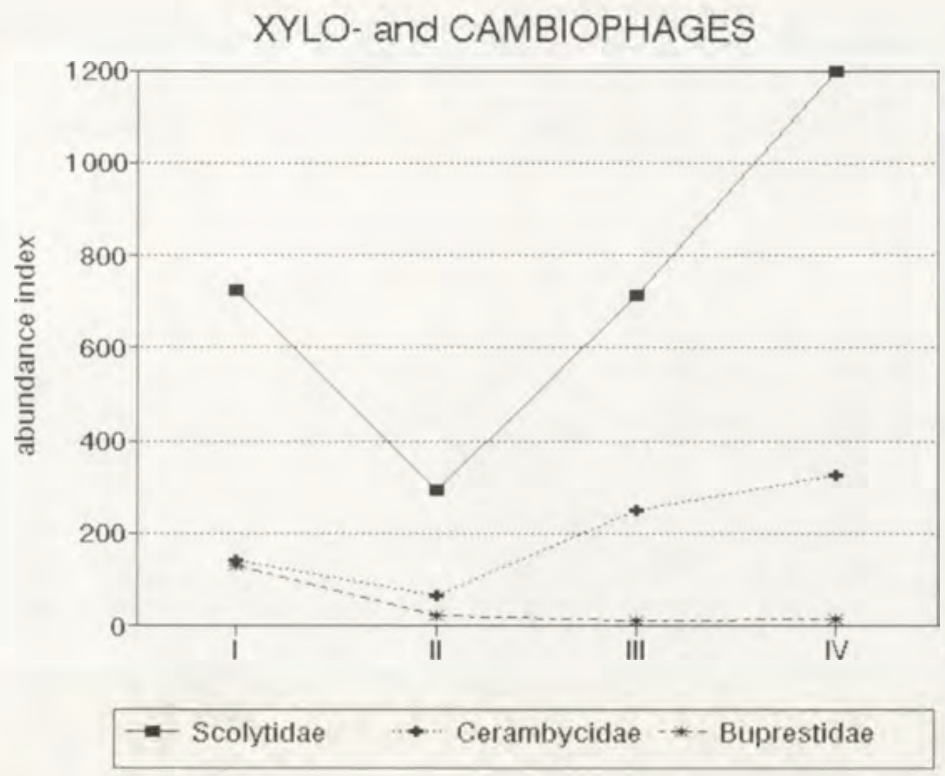

Fig. 17. Changes in the abundance of xylophages and cambiophages in pine forests of three age classes of the forest stand

\section{Bark beetles (Scolytidae)}

Bark beetle communities are characterised by a steady rise in the number of species throughout the sere (Fig, 16). The lowest number of species - 10-was recorded in the culture stage. Those species show an affinity for habitats forming immediately after felling and are more apt to inhabit fresh stumps (Hylurgos palliatus, Hylastes ater, $H$. opacus and Hylurgos lignipera). Some of them prefer the underground part of the stump due to higher moisture (Hylastes ater and H. opacus), others inhabit the whole of the stump (Mokrzycki, oral information). The species damage the bark and may occur in considerable abundance in 3-5-year-old cultures. In the young stand stage, the species composition of the bark beetle community is even richer: all the species occurring in the culture are still present, there appear species settling on trunks, such as Pityogenes quadridens, or characteristic of older stands, e.g. Ips sexdentatus. In older stands the species composition of the communities becomes richer still, owing to, among other factors, an influx of species settling on branches. The communities most similar in species composition are those inhabiting pole wood and mature stands (Søerensen's similarity index ranged among 81 to $100 \%$ ). The lowest abundance is noted for communities in young stands. In older stands, the abundance increases steadily, achieving a maximum in the mature stage (Fig. 17). Analysis of the structure of dominance reveals that the structure of the community is transformed in the course of succession since different species are dominant in the consecutive age classes (Fig. 18). The similarity of dominance structures of Scolytidae communities inhabiting older stands (pole 
wood, mature stands) is high. In younger stands (culture, young stands) on the other hand, community structures differ both from one another and from communities of older stands. It is therefore suggested that the communities become stable after the stand reaches the pole wood stage (MOKRZYCKI unpublished data).

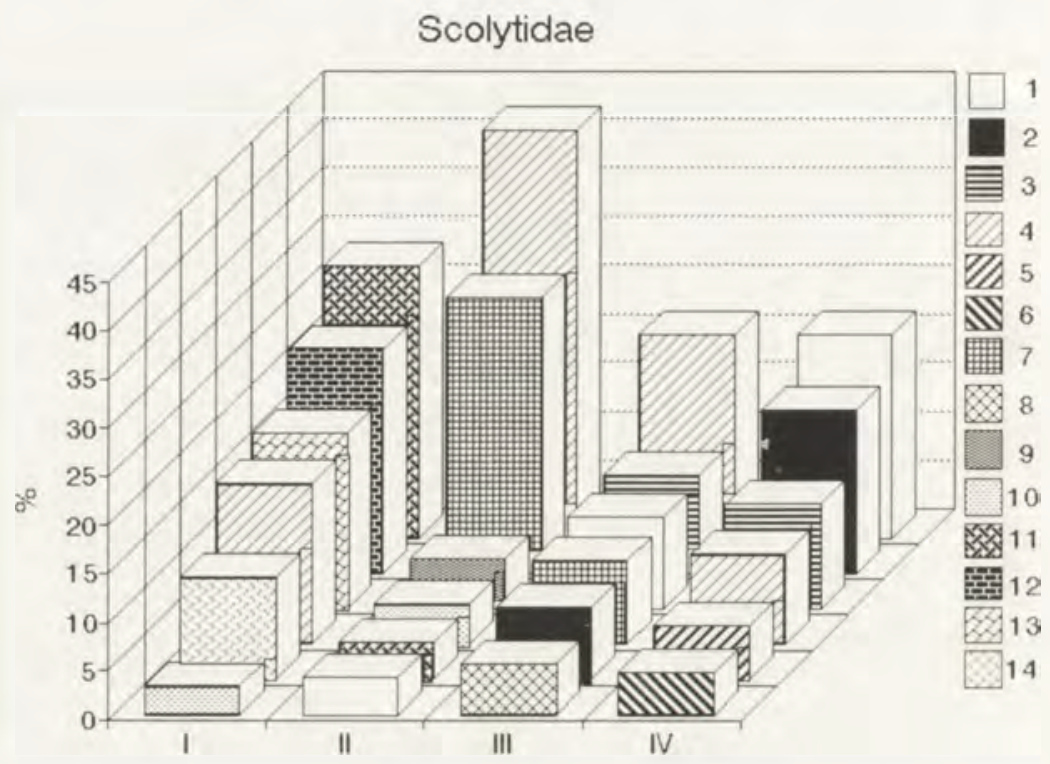

Fig. 18. Dominance structure of communities of bark beetles (Scolytidae) in forest stands of various ages in Puszcza Bialowieska; 1 -Crypturgus hispidulus, 2 -Crypturgus cinereus, 3 - Trypodendron lineatum, 4 - Tomicus piniperda, 5 -Ips acuminatus, 6 -Ips sexdentatus, 7 -Pityogenes bidentatus. 8 -Orthomicus suturalis, 9 - Pityogenes quadridens, 10 -Hylastes opacus, 11 -Orthomicus laricis. 12 - Hylurgops palliatus, 13 - Hylastes ater, 14 -Hylurgus lignipedra

\section{Longicorns (Cerambycidae)}

Longicorns communities are characterised by an increase in the number of species in the pole wood and mature forest stage as compared to young stands (Fig. 16). A similar number of species in every age class of pine forest (young stand, pole wood, mature stand) was recorded only in the case of tree canopies. The culture stage is characterised by a relatively rich Cerambycidae taxocoene, which is associated with the taxon settling stumps and what has remained after clearfelling. The species composition in the young stand stage is the poorest and most different in comparison to communities occurring in older stands. In the pole wood, the Longicorn beetle community is similar in species composition to the community inhabiting natural mature stands (Søerensen's index is 67\%) (GuTOWSKI unpublished data). In the sere under study, the abundance of Cerambycidae reaches the lowest values in young stands, and increases in the pole wood and mature stands (Fig. 17). In the Cerambycidae communities under 
investigation, Asemum striatum is dominant in the culture stage $(16.5 \%)$, Pogonocherus decoratus in young stands $(32.8 \%)$, Corymbia rubra in the pole wood (15.0\%) and Rhagium inquisitor in the mature stand (17.7\%) (Fig. 19).

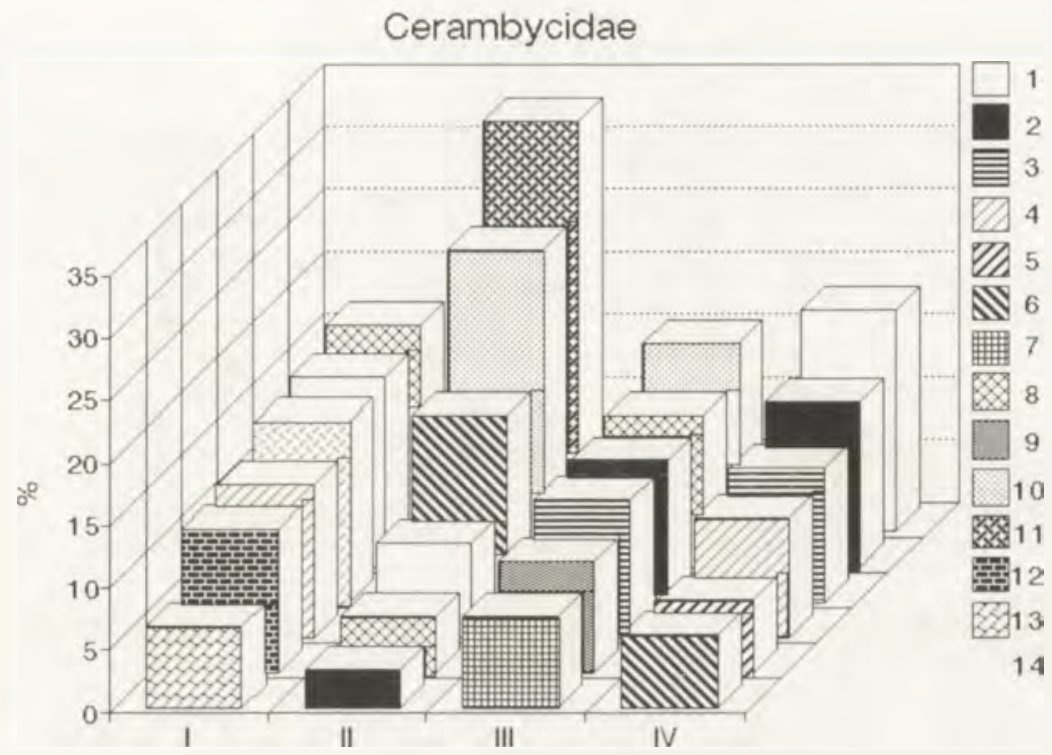

Fig. 19. Dominance structure of communities of Cerambycidae in forest stands of various ages in Puszcza Białowieska; 1 - Rhagium inquisitor, 2 - Stenurella melanura, 3 - Molorchus minor, 4 Arhopalus rusticus, 5 - Tetropium castaneum, 6 - Pogonecherus fasciculatus, 7 - Acanthocinus griseus, 8 - Asemum striataum, 9 -Callidium coriaceum, 10 -Corymbia rubra, 11 -Pogonecherus decoratus, 12 - Spondylis buprestoides, 13 - Callidium violaceum

\section{Buprestids (Buprestidae)}

The highest number of species is recorded in buprestid communities from pine cultures and significantly thinned mature forests (Fig. 16). The highest similarity of species composition was noted for communities of cultures, pole wood and mature stands (Søerensen's similarity index ranged emong 67 to $70 \%$ ). The abundance of Buprestidae community is the highest in the culture stage (Fig. 17). The same species, namely Anthaxia quadripunctata, is dominant in all the age classes of the pine forest sere and the communities inhabiting consecutive stages of forest stand development are characterised by relatively high similarity of dominance structures (Fig. 20). The most similar in this respect are communities occupying cultures and young stands, while the greatest differences in dominance structures were recorded for the culture and mature stand communities (GUTOWSKI unpublished data). 


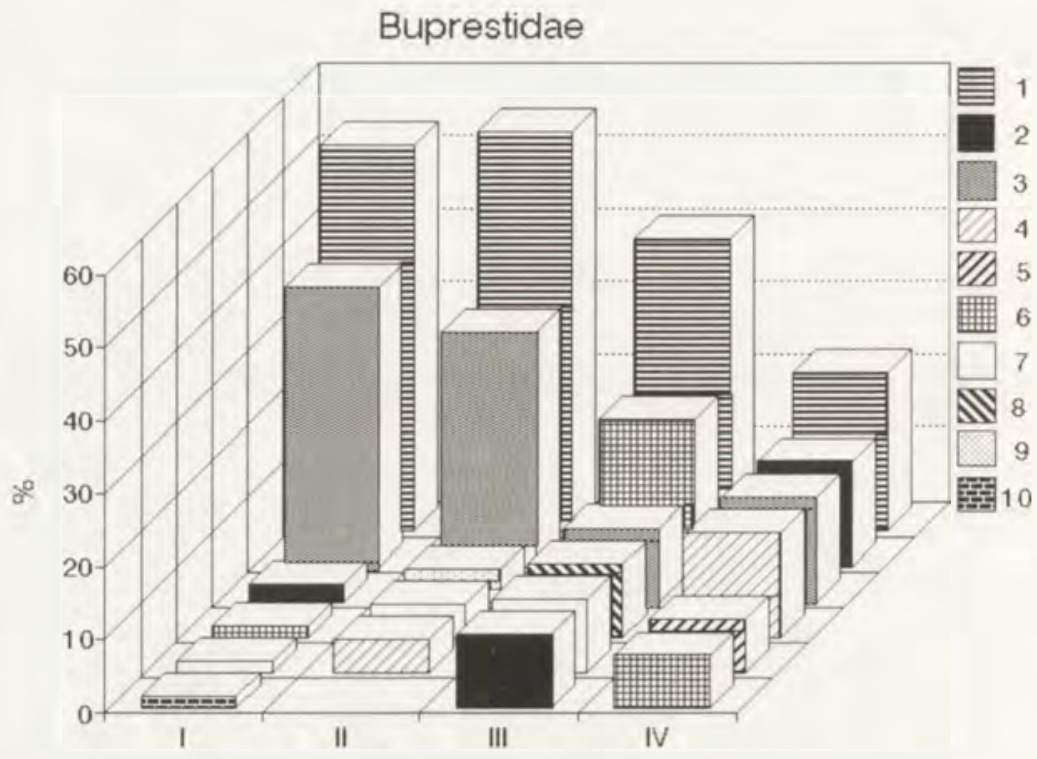

Fig. 20. Dominance structure of communities of buprestids (Buprestidae) in forest stands of various ages in Puszcza Bialowieska: 1 - Anthaxia quadripunctata, 2 - Chalcophora mariana. 3 - Buprestis rustica, 4 - Anthaxia submontana, 5 -Buprestis haemhorroidalis, 6 - Agrilus sulcicollis, 7 - Trachys minuta, 8 - Phaenops cyanea, 9-Buprestis octoguttata, 10-Agrilus angustulus

Analysis of changes in xylo- and cambiophage communities in the course of succession

Transformations of the communities of the xylo- and cambiophage groups studied are a little different in each group. The greatest number of species is noted for the xylo- and cambiophage communities occurring in mature stands (Fig. 16). Buprestidae and Cerambycidae are characterised by relatively high species richness in the culture stage as well, but Scolytidae are represented by the lowest number of species at this stage. Young stands are home to the lowest numbers of species of Buprestidae and Cerambycidae. The abundance of Scolytidae and Cerambycidae increases towards more mature stands, and it is only the markedly xerophilous Buprestidae that are most abundant in the culture stage. In the sere under investigation, the dominant species group of Scolytidae and Cerambycidae undergoes substantial transformation. Other species are dominant in younger stands than prevail in older ones, although the former dominant group is not completely supplanted. Buprestidae are the only taxon where one species (Anthaxia quadripunctata) is dominant in all the communities studied. In Scolytidae, Cerambycidae and Buprestidae, the group of dominants is composed of a number of species in every age class.

Analysis of similarity of empirical xylo- and cambiophage communities with the five theoretical statistical distributions showed that the distribution of 
species in the communities examined is closest to the negative binomial distribution (Scolytidae and Cerambycidae). In the case of Cerambycidae it is also similar to the logarithmic series (communities of cultures, pole wood and mature forest) and to the geometric series (young stands). In some instances, the estimated number of species is higher than the one actually recorded (Cerambycidae) which suggests the presence of higher species capacity of the habitat. In Scolytidae the estimated number of species corresponds to the actual one.

Species diversity, measured with Shannon and Weaver's index, is highest in mature stages (Scolytidae - pole wood, Buprestidae and Cerambycidae-mature stands) (Fig. 21). The degree of realisation of potential species diversity $\left(\mathrm{H}_{\max }\right)$ increases in generalfor the course of of the groups studied in each succession stage.
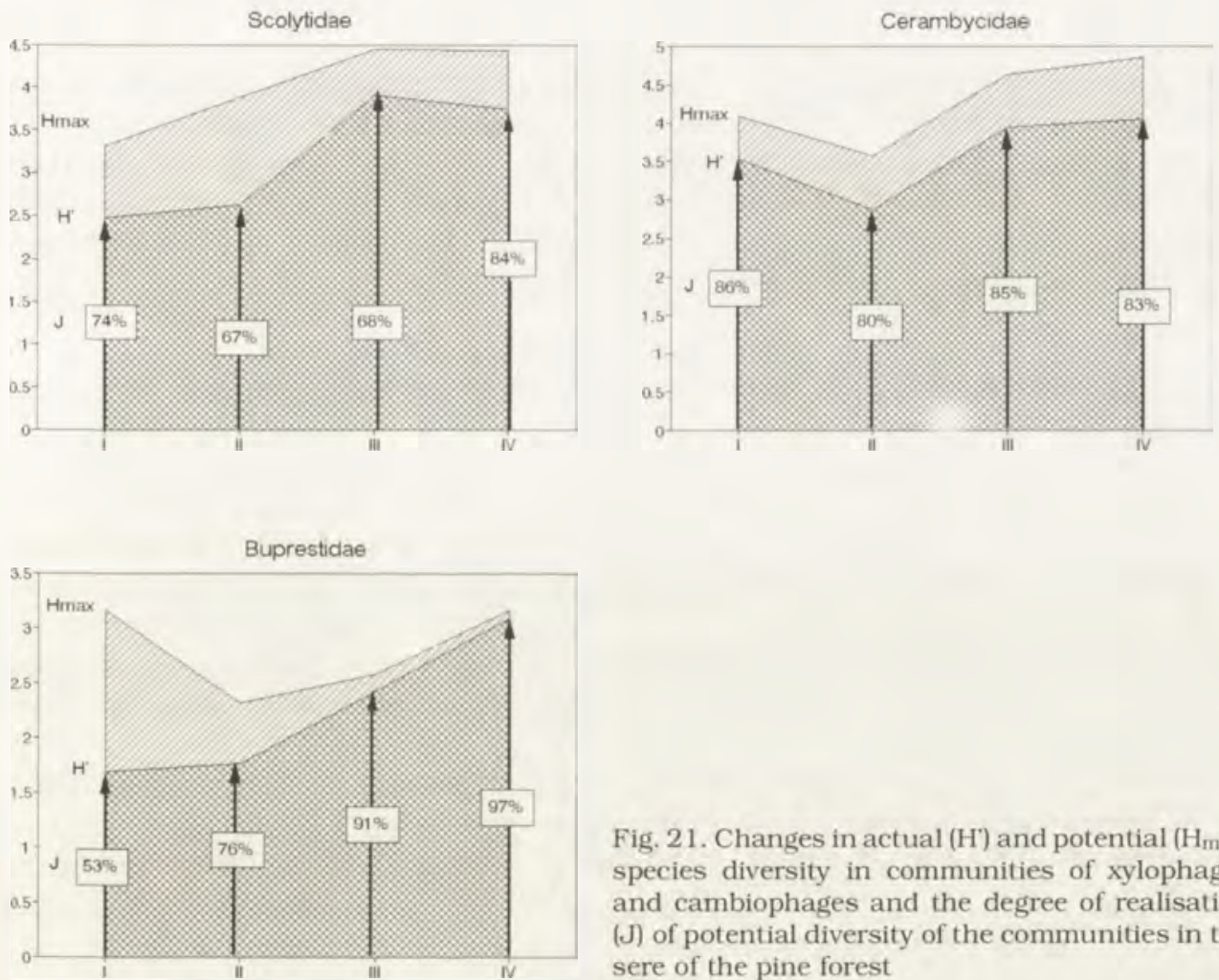

Fig. 21. Changes in actual $(\mathrm{H})$ and potential $\left(\mathrm{H}_{\max }\right)$ species diversity in communities of xylophages and cambiophages and the degree of realisation $(J)$ of potential diversity of the communities in the sere of the pine forest

Analysis of structures of the communities of selected xylo- and cambiophages permits a fuller description of the changes taking place in the succession stages studied in the pine forest sere.

The culture stage creates most favourable conditions for Buprestidae to reach a high abundance and a number of species similar to that of the mature forest. Cerambycidae are also characterised by relatively rich fauna at this stage. This http://rcin.org.pi 
is related to the possibility of settling in stumps, clearfelling remains and to high insolation which, is particularly crucial for the appearance of Buprestidae.

The young stands harbour the lowest numbers of Cerambycidae and Buprestidae species. The decaying stumps in young stands are no longer a suitable habitat for most species of Cerambycidae and Buprestidae, and the thin stems and branches combined with low exposure to sunlight do not provide a good feeding basis for a wider range of species. The situation may change if deadwood appears in younger age classes. Cambio- and xylophagous species of both groups may then increase their numbers. Bark beetle communities have richer species composition at this stage. The species composition of bark beetle communities becomes steadily richer as the forest grows older. Species characteristic of the subsequent stages start to appear while the species occurring in younger age classes do not retreat, but only change their positions in the structure of dominance.

The pole wood stage is a preparatory phase for the formation of communities characteristic of natural mature pine forests. Especially important for the development of xylophages and cambiophages is the appearance of litter, dead trees, development of the herb layer and an increase in insolation at this stage.

The analysis of the selected groups of xylo- and cambiophages revealed that the beetle groups studied become stabilised in older stands (pole wood). The xylo- and cambiophage fauna occurring at this stage most closely resembles the fauna of a natural mature forest.

\subsubsection{Epiphytic predators}

Predators preying in the ground cover, shrub and tree canopy layers may be divided into two groups playing different ecological roles of specialised and non-specialised predators. Prime examples of non-specialised predators (or forms with hardly-marked trophic specialisation) abundantly represented in the canopy layer of pine forest stands are spiders (Aranei), soldier beetles (Cantharidae, Coleoptera), robber-flies (Asilidae, Diptera) and digger wasps (Sphecidae, Hymenoptera). In specialised predators, one can find groups of aphidophagous species belonging to syrphids (Syrphidae, Diptera), digger wasps (Sphecidae, Hymenoptera), neuropterans (Neuropteroidea) and ladybirds (Coccinellidae, Coleoptera).

In pine forests these groups of predators exhibit high species richness, at the same time occurring in high abundances to play a doubtlessly significant role in the functioning of the biocenosis. From among non-specialised predators, large-sized forms may even attack larger animals, and the markedly sclerotised protective layer of their victims' bodies poses no obstacle for them. Adult robber-flies and digger wasps, which are good flyers, penetrate into all vegetation layers while hunting.

Web spiders of pine stands have been studied by LUCZAK (1963), spiders of middle-aged stands have been investigated by DZIABASZEWSKI (1976), and spiders living in forest stands of various ages have been analysed by STERZYNSKA and ŚLEPOWRONSKI (in press).

Pine forest robber-flies have not been dealt with in a separate paper to date. 
The species composition and dominance structure of digger wasp communities of these ecosystems have been analysed in papers devoted to Warsaw environs (SKIBIŃSKA 1981) and older pine stands in Byelorussia (SHLYAKHTENOK in press).

The species composition and dominance structure of syrphid communities have been presented in a paper on the pine forest of Puszcza Kampinoska and Białołęka Dworska (BAŃKOWSKA 1982). To date, there has been only one paper which compares the course of secondary succession of syrphid communities in three age classes of pine forest stands in three different pine forests (BAŃKOWSKA in press).

Ladybirds of older stands of pine have been analysed by HOREGOTT (1960), KLAUSNITZER (1968), KLOMP and TEERINK (1973) and CZECHOWSKA (1981).

Few papers have been devoted to neuropterans of pine forests (CZECHOWSKA 1985) and none of them is concerned with succession.

\section{Spiders (Aranei)}

75 spider species occur in the pine forest stands studied in all the age classes, with 51 species in young stands, 31 in the pole wood and 39 in mature stands (Fig. 22) (STERZYŃSKA unpublished data). 15 species were found to occur in every succession stage in the pine forest, accounting for about $20 \%$ of the spider fauna collected with Moericke's pitfall traps in the study areas. The species composition of spiders in young pine stands is characterised by a much greater uniqueness that the fauna registered in older stands. The degree of species composition similarity (So) of the young stand and pole wood communities was $46 \%$, and of
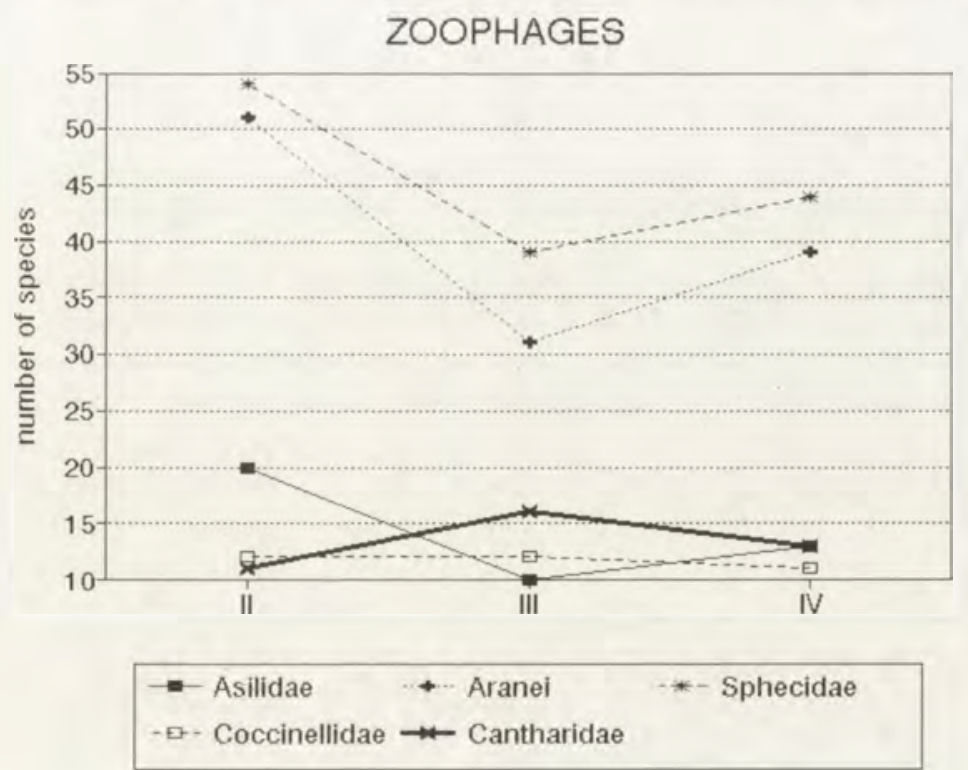

Fig. 22. Changes in the number of species of predators in pine forests of three age classes of the forest stand 
spider communities of young and mature stands $-44 \%$, while the figure for the pole wood and mature stands was $60 \%$.

The differences in abundance of spider communities in pine stands of various ages in Puszcza Białowieska were not as significant as differences in the number of species. The most abundant community lived in young stands, while in pole wood the community abundance was lower by about $40 \%$ and in mature forests - by $30 \%$ (Fig. 23).

\section{ZOOPHAGES}

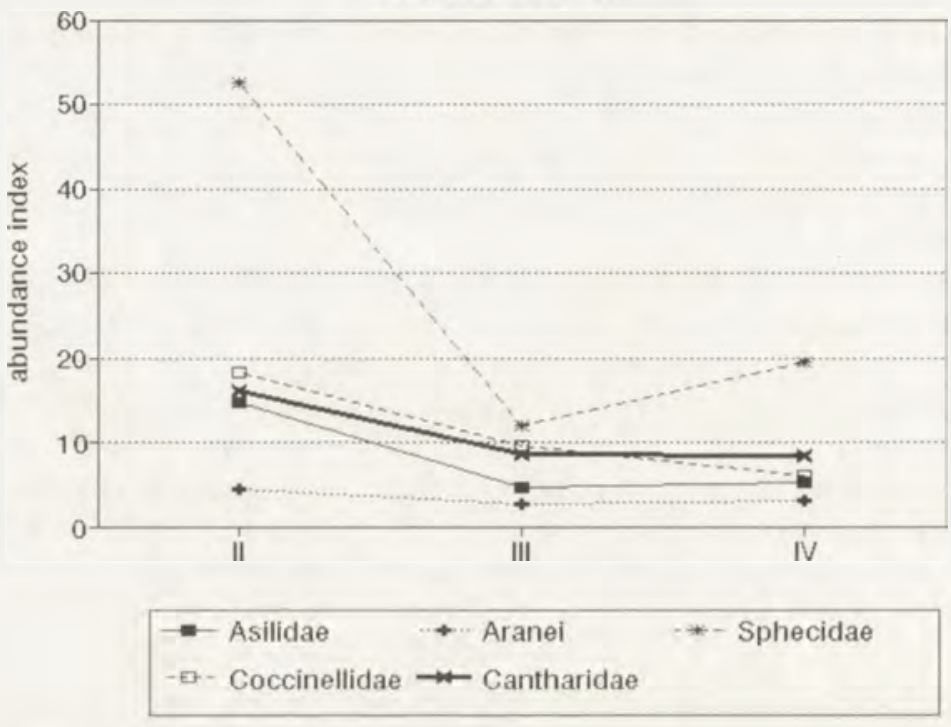

Fig. 23. Changes in the abundance of predators in pine forests of three age classes of the forest stand

The structures of dominance of spider communities were similar in all the succession stages of pine forests (Fig. 24). Heliophanus dubius was dominant in young stands and the pole wood, and subdominant in mature stands, where Diaea dorsata was the dominant species. From among the 10 most abundant species caught in canopies of pines, as many as 7 belonged to the group of species prevailing in all the forest stands studied. The species included: Heliophanus dubius, Anyphaena accentuata, Trematocephalus cristatus, Theridion tinctum, Diaea dorsata, Xysticus cristatus and Atea sturmi. The share of this group was significant in each community exceeding $45 \%$ in young stands, reaching nearly $65 \%$ in pole wood and about $50 \%$ in mature stands. All of the above species are forest polytopes, associated mostly with coniferous forests. Only T. cristatus is considered to occur more often in deciduous forests (STERZYNSKA unpublished data).

As the stands grew older, the abundance of $H$. dubius, A. accentuata, T. cristatus and T. tinctum decreased while the abundance of $D$. dorsata and $A$. 


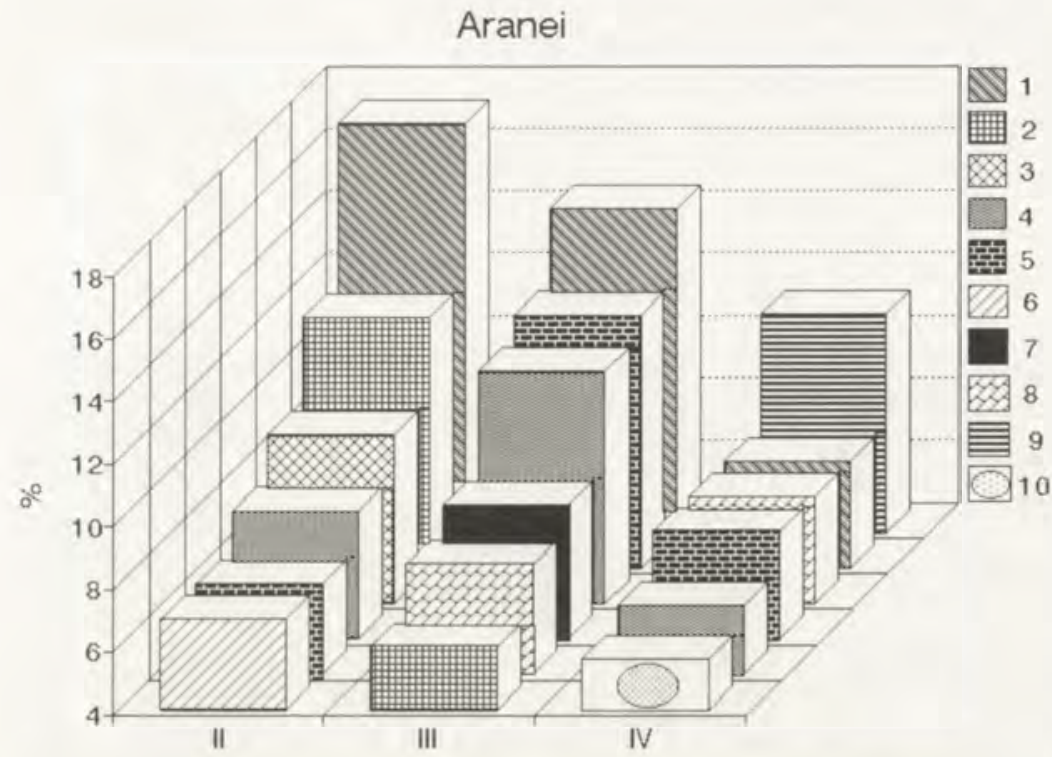

Fig. 24. Dominance structure of communities of spiders (Aranei) in forest stands of various ages in Puszcza Bialowieska; 1 - Heliophanus dubius, 2 -Euryclubiona subsultans, 3 -Dendryphantes rudis, 4 - Anyphaena accentuata. 5 - Trematocephalus cristatus, 6 -Entelecara congenera, 7 - Theridion tinctum , 8 - Atea sturmi, 9-Diaea dorsata, 10 - Dictyna arundinacea

sturmi rose together with their ranks in the community as they occupied higher positions in the structure of dominance in older stands. In the case of $X$. cristatus the abundance remained the same in all the pine stands studied, while its share in older stands' communities increased since the total abundance of these communities was lower than the abundance of the young stand spider community.

\section{Soldier beetles (Cantharidae)}

In the pine forest stands studied in Puszcza Białowieska soldier beetles were represented by 16 species (СНовотоw 1993), all of which were registered in medium age stands. The community poorest in regard to species composition (11 species), but at the same time the most abundant, was found in young stands (Fig. 22). 11 species were found to be common to all the communities studied, so that soldier beetle communities were characterised by a high degree of species composition similarity. The values of Søerensen's index ranged from $81 \%$ to $92 \%$. The composition of the dominant species group in the beetle communities was quite similar in the stands of various ages, but the young stand soldier beetle community was a little more unique than communities of older stands (Fig. 25). The two co-dominant species from young stands, Cantharis nigricans and $C$. pellucida functioned as subdominants in older stands; in the pole wood the co-dominants were $C$. obscura (a subdominant in young stands) and http://rcin.org.pl 
Rhagonycha lignosa, which became a strong dominant in mature forest. A characteristic finding is that polytopic species were dominant in young stands, while other forms predominated in older stands - a forest polytope and coniferous forest oligotope in the pole wood, and a coniferous forest oligotope in the mature forest.

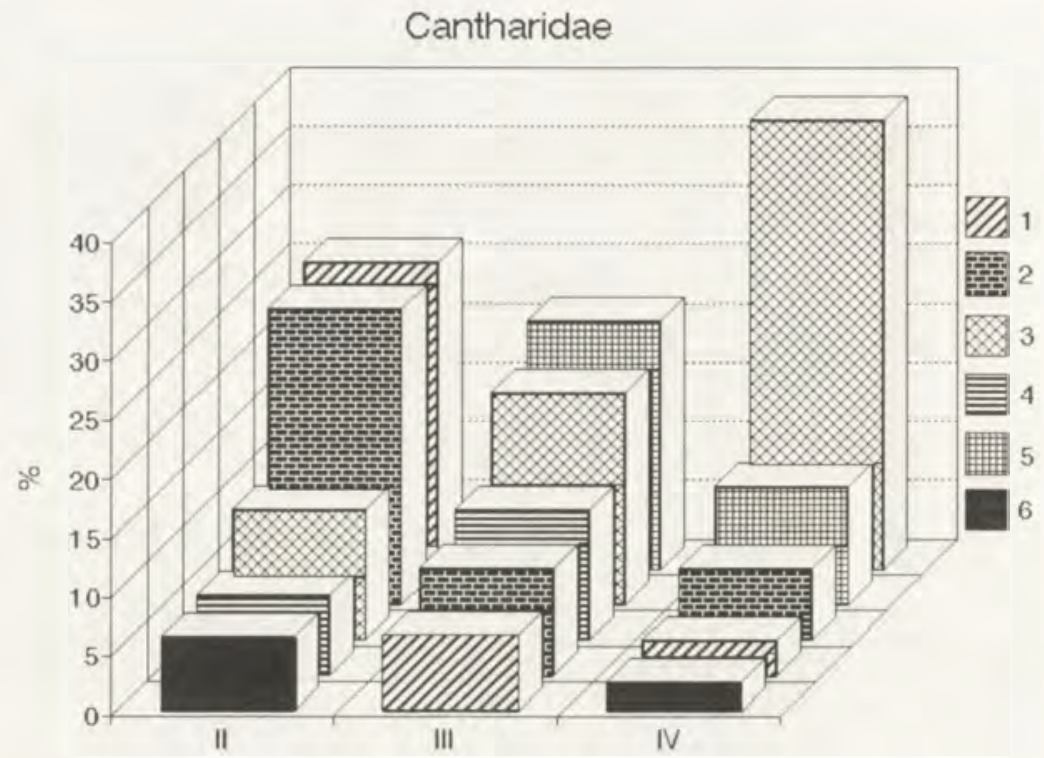

Fig. 25. Dominance structure of communities of cantharides (Cantharidae) in forest stands of various ages in Puszcza Białowieska; 1 - Cantharis nigricans, 2 -Cantharis pellucida, 3-Cantharis obscura, 4-Rhagonycha limbata, 5. Rhagonycha lignosa, 6-Rhagonycha elongata

Just like in the case of spiders, robber-flies (Asilidae) (TROJAN unpublished data) and digger wasps (Sphecidae) (SKIBIŃSKA unpublished data) were also represented by a much higher number of species in young stands (Fig. 22). Those predatory insects vere also more abunciant in young stands.

Robber-flies (Asilidae)

A total of 22 species of Asilidae were found in the pine forest stands studied in Puszcza Białowieska, as many as 20 of which were registered in young stands compared to 10 species caught in the pole wood and 13, in mature stands. Most of them were rather common species, with the exception of Lasiopogon immaculatus, a species only recently found in Poland and characteristic of Puszcza Białowieska. The species was among the most abundant species in mature forests. 9 species were found to be common to all the stands studied. A high degree of species composition similarity was noted for Asilidae communities of older stands, with Søerensen's index equalling $78 \%$ for pole wood and mature forest communities. 
The abundance of Asilidae communities in pole wood and mature forests was similar and nearly three times lower than the abundance of the dipteran community in young stands (Fig. 23).

From the viewpoint of the composition of the most abundant species group, the structure of dominance was similar in all the succession stages of pine forests (Fig. 26) with Neoitamus cyanurus functioning as a dominant and $N$, socius, as a subdominant. The abundance of each of the two species was much lower in mature than in young forests. The group of the most abundant species in all the communities studied included also Tolmerus atricapillus. The contribution of these species to robber-flie communities was significant and amounted to over $80 \%$ in young stands, over $90 \%$ in pole wood and almost $70 \%$ in mature stands.

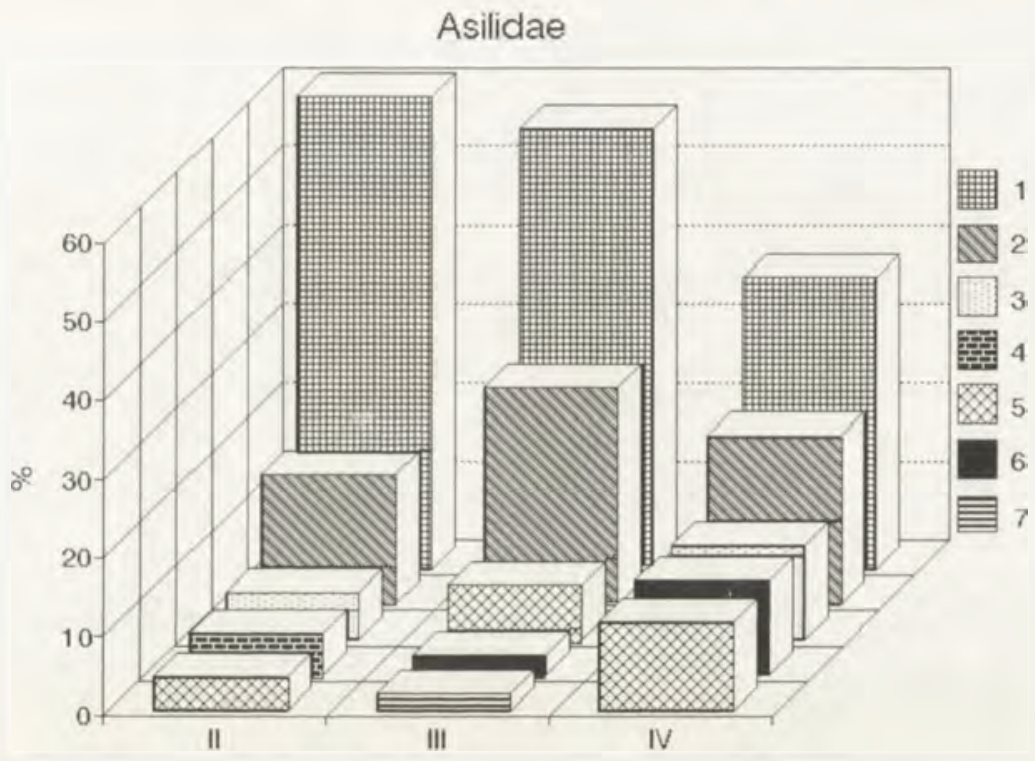

Fig. 26. Dominance structure of communities of Asilidae in forest stands of various ages in Puszcza Białowieska; 1 - Neoitamus cyanurus . 2 -Neoitamus socius, 3 -Neoitamus cothurnatus, 4 -Dioctria hyalipennis, 5 -Tolmerus atricapillus, 6 -Lasiopogon immaculatus, 7 -Epitriptus arthiticus

\section{Digger wasps (Sphecidae)}

In the pine forest sere of Puszcza Białowieska 77 species of digger wasps were found, accounting for $1 / 3$ of the total number of digger wasps ever found in Poland. This group of predators was also richest in young stands both in the number of species and in abundance. 53 species were found in young stands, 39 in the pole wood and 44 in mature stands.

The degree of species composition similarity was $57 \%$ for the young stand and pole wood digger wasp communities, $54 \%$ for the young and mature stand communities and $70 \%$ for the pole wood and mature stand communities of Sphecidae. Studies of Sphecidae in other habitats show that a value of http://rcin.org.pl 
Søerensen's index equalling $70 \%$ is extremely high for this taxon. It may be thus contented that in older stands of pine Sphecidae are represented by a taxocoene of a rather uniform species composition.

Considerable differences were, however, noted in community abundance. The digger wasps of young stands were nearly five times as abundant as in pole wood and almost three times as numerous as in mature forests (Fig. 23).

The structure of dominance of pine forest digger wasp communities in Puszcza Białowieska is characterised by a strongly marked position of the all-stage dominant - Mellinus arvensis (Fig. 27). Two species with a lower rank - Crabro cribrarius and Pemphredon balticus - are in the group of 10 most abundant species that are present in each age class of the forest stand. In total. the three species accounted for about $87 \%$ of the total abundance of the young stand community, compared to about $60 \%$ of the communities inhabiting pole wood and mature forests.

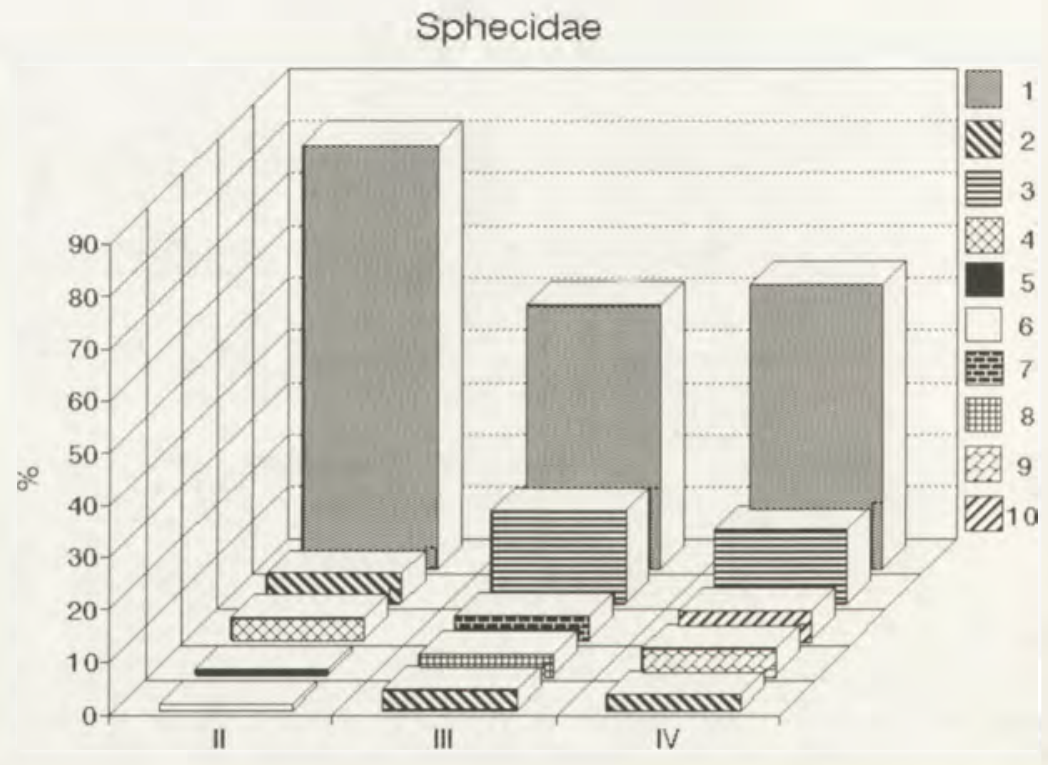

Fig. 27. Dominance structure of communities of digger wasps (Sphecidae) in forest stands of various ages in Puszcza Białowieska; 1 - Mellinus arvensis, 2 - Crabro cribrarius, 3 - Passaloecus insignis, 4 - Crabro scutellatus, 5 - Nysson spinosus, 6 - Ammophila pubescens, 7 - Pemphredon balticus, 8 - Pemphredon lugubris, 9 - Trypoxylon figulus, 10 - Trypoxylon minus

The character of the structure of dominance of digger wasp communities confirms the close relationship of communities occurring in older stands and the more unique character of the young stand community. Among the 10 most abundant species in the communities inhabiting the pole wood and young stands, there were 4 common species: Mellinus arvensis, Crabro cribrarius, Pemphredon balticus and Passaloecus turionum; a similar comparison for pole wood and mature stand communities yielded 7 common species - Mellinus 
arvensis, Crabro cribrarius, Pemphredon balticus, Passaloecus insignis, P. eremita, Rhopalum clavipes and Entomognathus brevis.

One may speak of trophic specialisation among Sphecidae, at least some species of the taxon. The greatest number of species and the highest abundance characterizes the group of digger wasps, whose diet consists predominantly of various dipterans. In the pine forests studied in Puszcza Białowieska this trophic group was represented by a total 27 species. In young stands, the abundance of 22 of these species accounted for $94 \%$ of the total community abundance. In older stands, the group was much poorer both in the number of species and abundance, with 12 species recorded in the pole wood and 14 in mature stands and the abundance being several times lower than in young stands. The degree of similarity of the Sphecidae communities which feed their offspring with dipterans was $65 \%$ for young stands and the pole wood, $56 \%$ for young as compared to mature stands and $70 \%$ for the pole wood and mature forest.

Similar trends in changes in the number of species and abundance can be observed in the group of Sphecidae which feed their offspring with larvae of butterflies and sawflies ( 8 species altogether): in older stands this group is nearly 15 times less abundant than in young stands.

Reverse trends are observed in the groups of digger wasps which feed their offspring with aphids or spiders. The rank of this group rises considerably in older stands, where only a slight increase in the number of species takes place, but the abundance surges substantially. The group feeding their offspring with spider is not numerous ( 5 species) and 20 times more abundant in mature than in young stands.

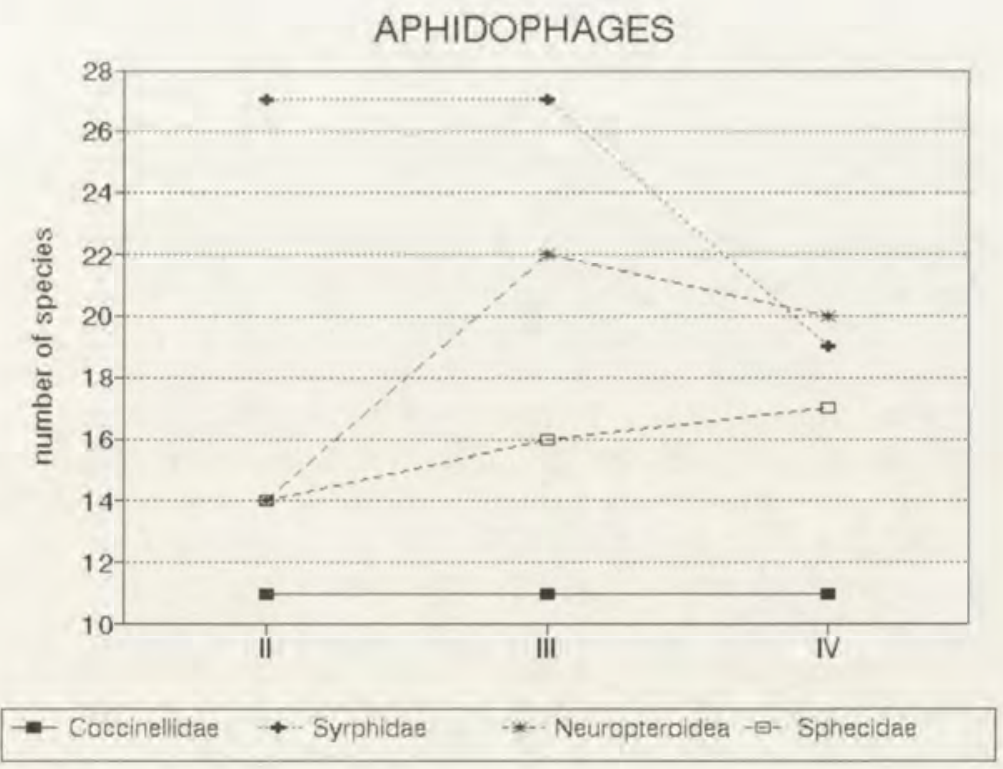

Fig. 28. Changes in the number of species of aphidophages in pine forests of three age classes of the forest stand 
The aphidophagous digger wasp group is represented in the pine stands studied in Puszcza Białowieska by 22 species with 14 species in young stands, 16 in the pole wood and 17 in mature stands (Fig. 28). The degree of species composition similarity (So) was as high as $90 \%$ for the pole wood and mature stands, and $64-66 \%$ for young as compared to older stands. In the pole wood, the aphidophages were three times as abundant as in young stands (four times more abundant in mature stands than in young ones) (Fig. 29).

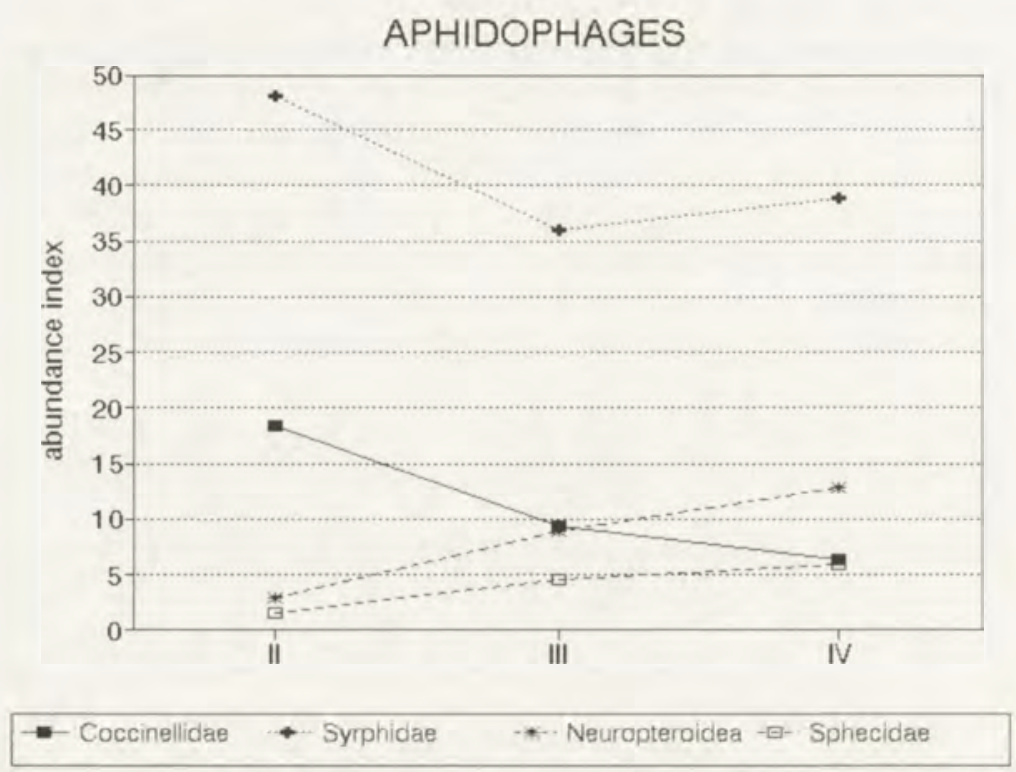

Fig. 29. Changes in the abundance of aphidophages in pine forests of three age classes of the forest stand

Neuropterans (Neuropteroidea)

Like aphidophagous Sphecidae, aphidophagous Neuropteroidea also increase the number of species and abundance as the stand grows older (Fig. 28-29) (CZECHOWSKA unpublished data). The total number of species recorded was 23, with 14 registered in young stands, 22 in the pole wood and 20 in mature stands. About $58 \%$ of the Neuropteroidea fauna (13 species) were found in every succession stage of the pine forest studied in Puszcza Białowieska. Community abundance in the pole wood and mature forest was three and four times higher than in young stands respectively (Fig. 29). The majority of the species registered were more abundant in older than younger stands. In the stands of various age under investigation the composition of the most abundant species group in neuropteran communities was similar (Fig. 30). Among the 10 most abundant species in each age class there were five common species. In young stands their shares amounted to $70 \%$ of total community abundance, while in older stands the figure was about $85 \%$. The character of the structure of dominance testifies 
to the close relationships between pole wood and mature stand Neuropteroidea communities.

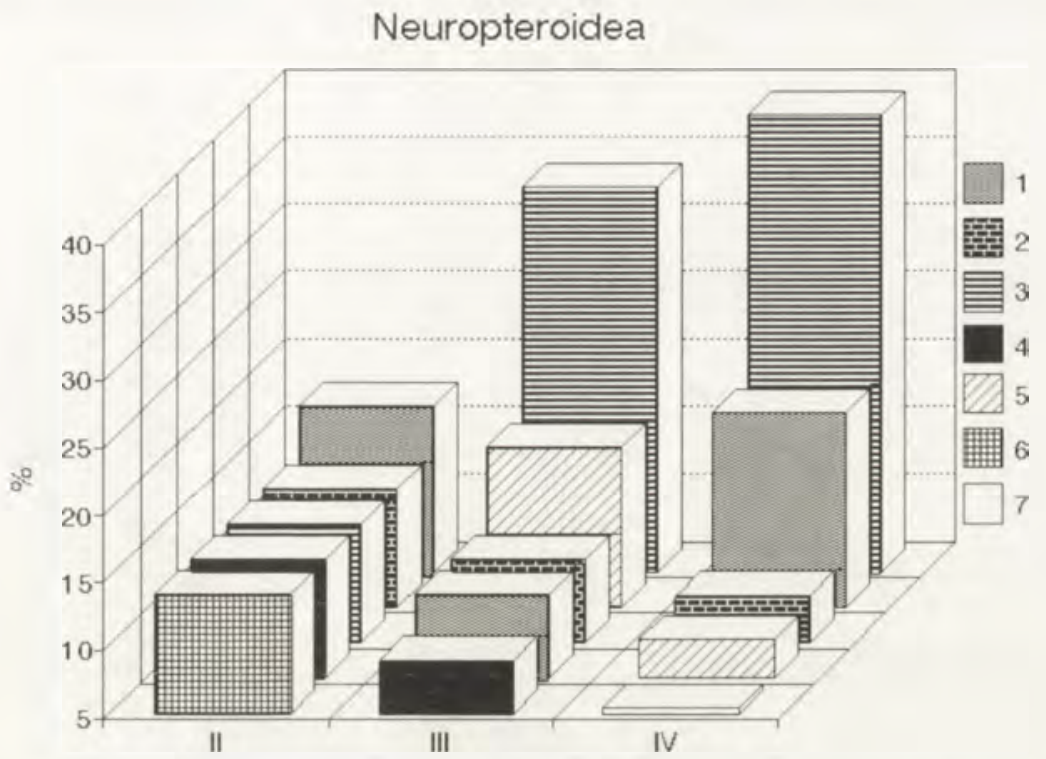

Fig. 30. Dominance structure of communities of neuropterans (Neuropteroidea) in forest stands of various ages in Puszcza Białowieska: 1 -Mallada prasinus, 2 -Wesmaelius concinnus, 3 - Raphidia xanthostigma, 4 -Raphidia notata. 5 - Hemerobius stigma, 6 -Coniopteryx parthenia, 7 - Chrysopa septempunctata

Syrphids (Syrphidae)

Communities of aphidophagous dipterans of the family Syrphidae revealed a reverse tendency: as the stand grew older, there was a decrease in both abundance and the number of species (Fig. 28-29) (BANKOWSKA in press). This phenomenon is due to the elimination, in older stands, of species associated with other habitats (meadows) which can occur in considerable abundance in young stands (e.g. Pipizella varipes). On the other hand, older stands see a rise in the abundance of species closely associated with pine forest (e.g. Dasysyrphus venustus, Didea intermedia). The total number of aphidophagous syrphid species registered in the pine forests studied in Puszcza Białowieska was 41, 13 of which were recorded in every age class of the forest stands. The species composition of aphidophagous syrphid communities inhabiting stands of various age was quite similar, but the community living in young stands was more unique when compared to communities inhabiting older stands. The values of Søerensen's index were $60 \%$ for communities from young stands and the pole wood, and $65 \%$ for communities from pole wood and mature stands. Episyrphus balteatus, Metasyrphus corollae and Dasysyrphus venustus were dominant in all the communities studied (Fig. 31). Episyrphus balteatus was a little less abundant in older stands than in young stands, but its proportion in the community 
increased due to the lower abundance of the whole community of aphidophagous Syrphidae in older stands. Analogous trends can be detected in Metasyrphus corollae, which undergoes an evident decrease in abundance (nearly 2 time:s), while the third dominant species of Syrphidae-Dasysyrphus venustus doublles its abundance in older stands.

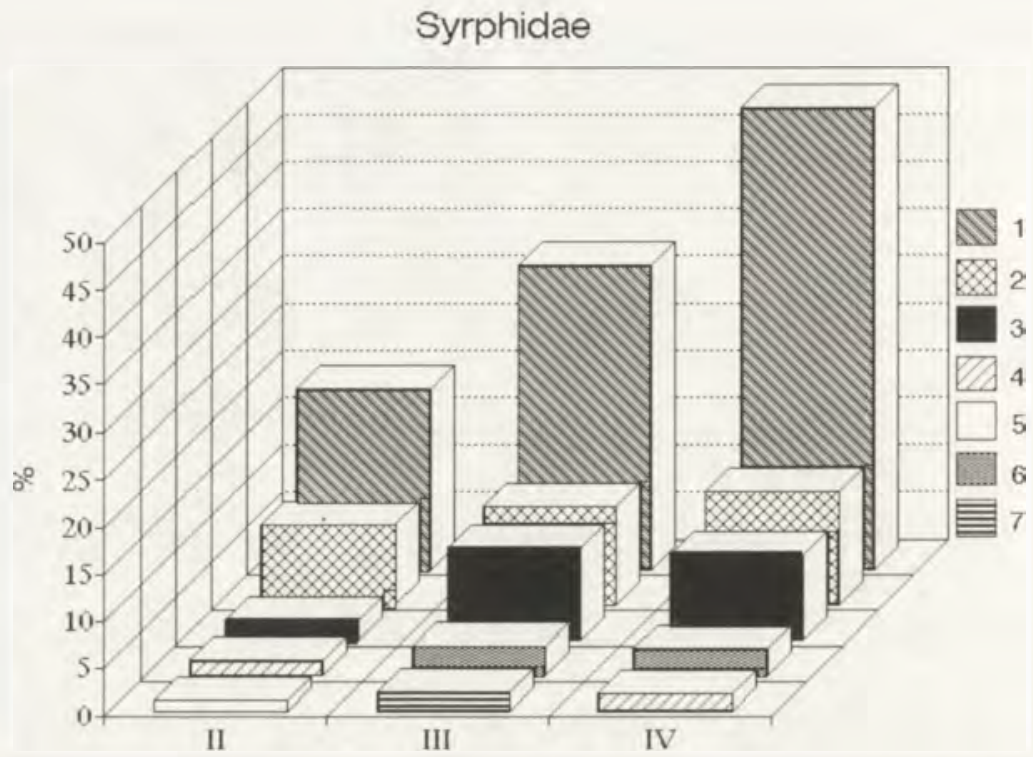

Fig. 31. Dominance structure of communities of syrphids (Syrphidae) in forest stands of various ages in Puszcza Białowieska: 1 - Episyrphus balteatus, 2 - Metasyrphus corollae, 3 -Dasysyrphus venustus , 4 -Melanostoma mellinum, 5 -Sphaerohoria menthastri, 6 -Didea intermedia, 7 -Syrphus torvus

Aphidophagous lady-birds (Coccinellidae) are represented by the same number of 11 species in each stand studied (Fig. 28). (CZECHOWSKA unpublished data). The species composition of this insect group in stands of various aged situated in the pine forest of Puszcza Białowieska was similar. A total of 13 species was registered including 9 common to each succession stage studied. Søerensen's index ranged from $83 \%-87 \%$. While no significant differences occurred in regard to the species composition of the communities, there were differences in abundance (Fig. 29). As the stands grow older, ladybird communities decrease in abundance. In the pole wood the abundance of the community was twice lower and in mature stands three times lower, than in young stands.

The structure of dominance was similar in the communities as far as the most abundant species group was concerned (Fig. 32). In all the communities under investigation, the most numerous species included Scymnus suturalis and Myrrha octodecimguttata, which collectively accounted for about $87 \%$ of total community abundance in young stands and the pole wood, compared with $73 \%$ 
in mature forests. Coccinella septempunctata was another rather abundant species in young stands. In older stands the species reduced its abundance just like Scymnus suturalis.

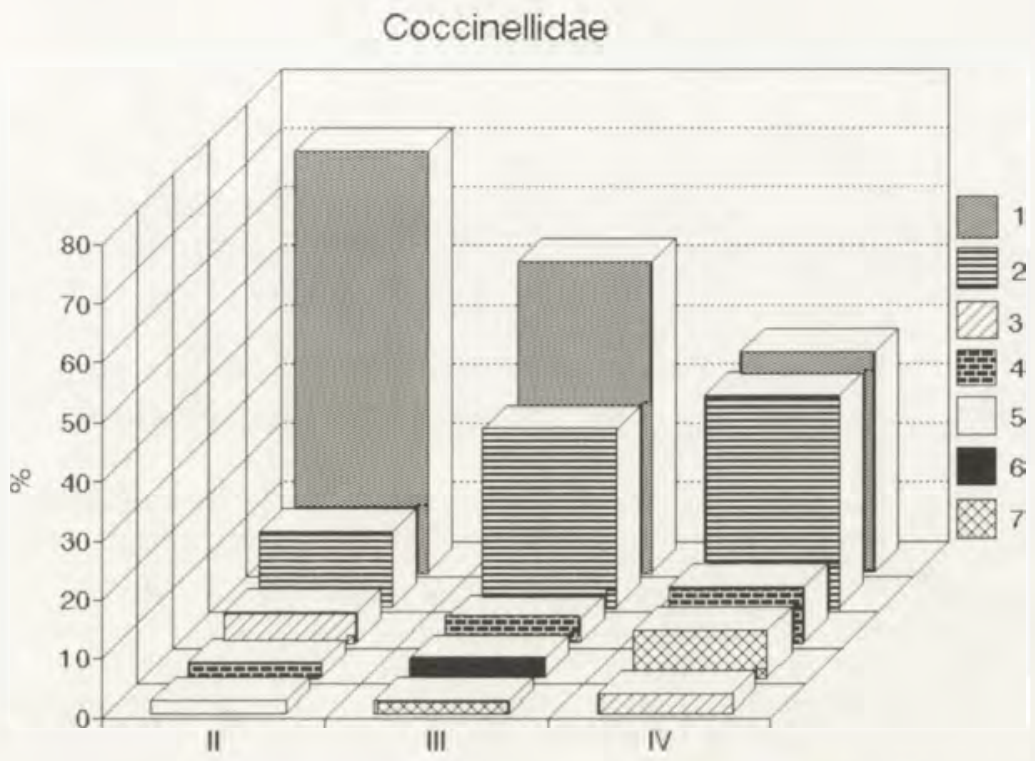

Fig. 32. Dominance structure of communities of aphidophagous coccinelids (Coccinelidae) in forest stands of various ages in Puszcza Bialowieska; 1 - Scymnus suturalis, 2 -Myrrha octodecimpunctata. 3 - Coccinella septempunctata, 4 - Harmonia quadripunctata, 5 -Calvia quatuordecimpunctata, 6 Mysia oblongoguttata, 7 - Anatis ocellata

8 species of aphidophagous Coccinellidae develop on coniferous trees. Their total proportion in the community was $91 \%$ in young stands and about $96 \%$ in older stands (pole wood, mature stands). As for species closely associated with pine, namely Scymnus suturalis, S. nigrinus, Harmonia quadripunctata and Myrrha octodecimguttata, their total share in the Coccinellidae community was about $86 \%$ in young stands and the pole wood and $82 \%$ in older stands.

The remarkably high qualitative and structural similarity between communities of aphidophagous Coccinellidae in the canopy layer of pine stands of various age results from this habitat being colonized by species with definite habitat and trophic requirements. $80 \%$ of a community was composed of stenotopic species, feeding only on pine aphids. Attention should be paid to the fact that the eurytopic species (Coccinella septempunctata and Calvia quatuordecimpunctata) were more abundant in the community inhabiting young stands $(7 \%)$ than in older stands $(3.2 \%-3.9 \%)$.

Communities of predatory arthropods occurring in pine stands of various ages in Puszcza Białowieska can be classified into two groups: one comprising predators from young stands, the other composed of forms which inhabit older stands. Young stand arthropod communities are usually more unique that those 
registered in pole wood and mature stands. Communities from older stands were similar to one another in species composition, dominance structure, uniformity of distribution and abundance. This regularity was observed in communities of both non-specialised predators and of aphidophages.

The degree of similarity of species composition of predators is higher for communities from older stands (pole wood and mature stands). The value of Søerensen's index for all the communities studied in older stands ranges from $65 \%$ for aphidophagous Syrphidae to $90 \%$ for communities of Cantharidae, Neuropteroidea and aphidophagous Sphecidae. The degree of species composition similarity between communities occurring in young stands and older stands is lower ranging from $54 \%$ for Sphecidae communities of young and mature stands to $97 \%$ for communities of Coccinellidae from young and mature stands. Cantharidae communities inhabiting young and mature stands are the only pair as similar to each other as communities from older stands.

The species composition of communities of such predators as Asilidae, Aranei, Sphecidae and Syrphidae was much richer in young stands than in older stands. On the other hand, Neuropteroidea, Cantharidae and aphidophagous Sphecidae were composed of a higher number of species in older stands, while aphidophagous Coccinellidae communities consisted of the same number of species in each age class.

In the majority of communities registered in young stands, there were higher proportions of both species from other habitats, not associated with pine forests, and of eurytopic species, than in communities studied in older stands. In older stands, species of open areas (meadows) are eliminated or their abundance decreases considerably, while forest polytopes and coniferous forest oligotopes remain, often increasing their abundance. Such a result of research conducted in Puszcza Bialowieska has been confirmed by studies concerned with certain groups of predators (Aranei, Syrphidae, Coccinellidae, Neuropteroidea. Sphecidae) in pine forests situated in other regions of Poland (Bory Tucholskie. Puszcza Biala).

Significant changes were observed in abundance of individual groups of predatory arthropods. A decreasing pattern of abundance is characteristic of communities of Asilidae, Cantharidae, Aranei and Sphecidae. Such a direction of abundance changes was also registered for communities of polyphagous dipterans of the family Dolichopodidae, which are not, however, thoroughly analysed in the paper, but, nevertheless, occur numerously in canopies of pine forests in Puszcza Białowieska. Another group of non-specialized predators, namely spider wasps (Empididae), was also relatively abundant in the canopy layer. The dipterans occurred in approximately the same abundance in young stands and mature stands, whereas they were a little more abundant in the pole wood, but the differences were not significant (the pole wood community abundance was $25 \%$ higher than community abundance in young stands).

Among aphidophages, all the most abundant taxons are thoroughly analysed in the present paper. Although this group has the same trophic preferences, individual taxons forming the guild exhibited diverse patterns of changes in the 
Asilidae

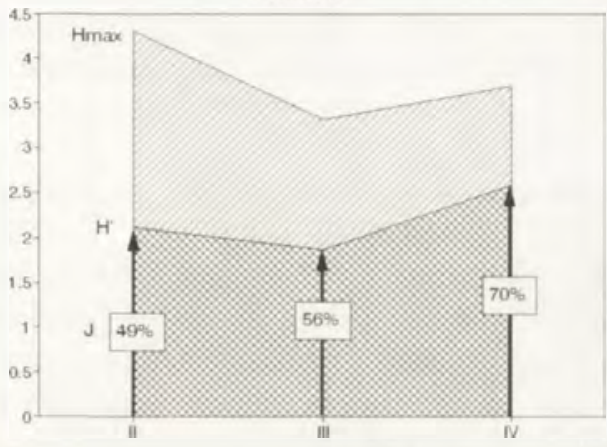

Sphecidae
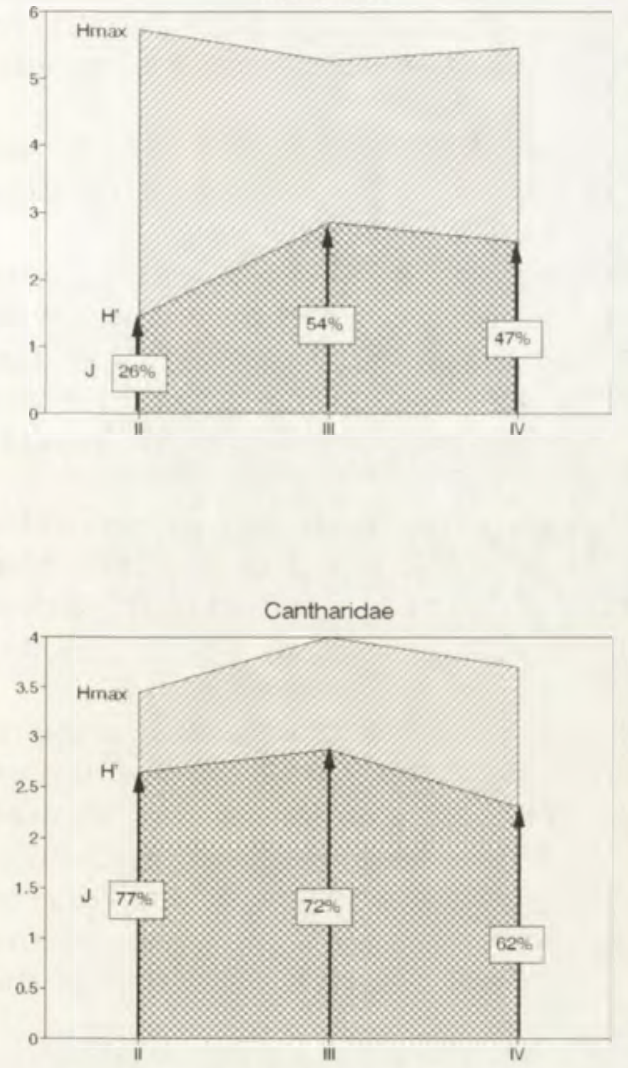

Aranei

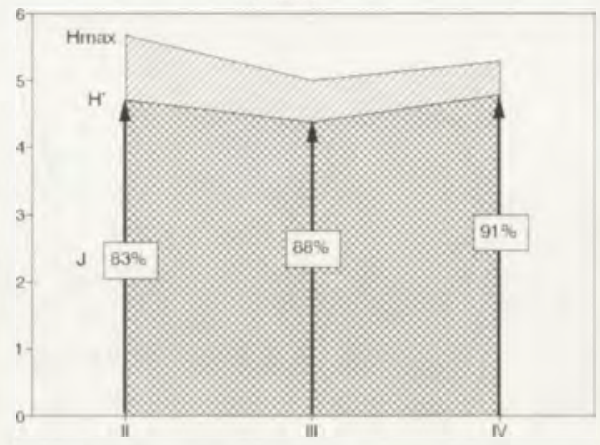

Coccinellidae

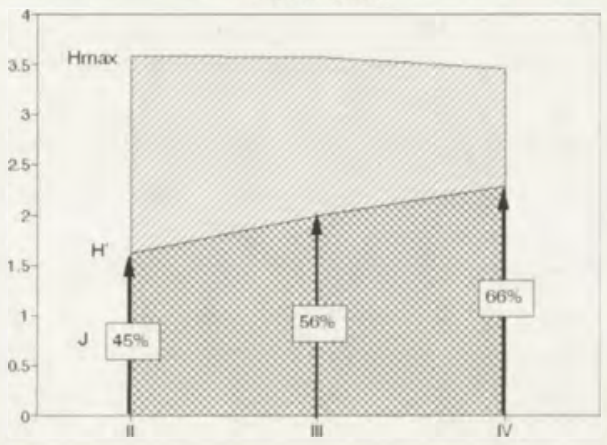

Fig. 33. Changes in actual $\left(\mathrm{H}^{\prime}\right)$ and potential $\left(\mathrm{H}_{\max }\right)$ species diversity in communities of non-specialised predators and the degree of realisation $(\mathrm{J})$ of potential diversity of the communities in the sere of the pine forest 
pine forest sere. The changes, both in respect to the number of species and abundance, are balanced, resulting in small total alterations.

Communities of predators in the pine stands of various age investigated in Puszcza Białowieska displayed similar structures. In all age classes of the stands, the group of dominants has similar species composition. The differences consist in changes of particular species' positions in the structure of dominance i.e. changes of their ranks in the communities.

Analysis of similarity of abundance distribution in the actual (empirical) communities of predators to the five theoretical statistical distributions revealed that most of the actual distributions are related to the negative binomial distribution and the logarithmic series. The similarity is significant for various groups in various pine forest succession stages: for robber-flies and aphidophagous digger wasps in the pole wood, for aphidophagous syrphids in young and mature forests. The distribution of abundance in soldier beetle communities is also closest to the negative binomial distribution (in young and mature stands) being also the only one to bear similarity to the lognormal distribution (in young stands). The distribution of spider community abundance is to some extent similar to the geometric series type of distribution (in the pole wood). The estimated number of species for all groups of predators (except the young stand community of soldier beetles) was higher than the empirical one, which suggests greater potential capacity of these habitats.

Quantitative structures of digger wasp, ladybird and neuropteran communities did not bear any similarity to any of the theoretical distribution models.

Species diversity of non-specialised predators (Fig. 33) depends on the group of animals studied. The highest actual diversity was recorded for spiders, with absence of significant differences between the various stages of succession. The maximum diversity, which is a measure of the potential habitat capacity, is also high in the case of spiders, while the degree of approximation of the habitat potential is the highest in this group $(\mathrm{J}>80 \%)$.

Similar patterns of changes, but occurring on a lower level, were observed for actual and potential species diversity in Asilidae. Here, actual diversity also decreases in the pole wood, whilst maximum diversity is attained in the oldest stands. The degree of approximation of the actual diversity to the habitat potential increases visibly in the consecutive stages of the sere (Fig. 33).

The lowest values of actual species diversity were noted for digger wasps (Sphecidae) in young stands of pine. In older stands the species diversity rises nearly two times. The actual species diversity of digger wasps is most distinct from the potential in the pine forest, particularly in young stands where $\mathrm{J}=26 \%$.

A steady increase is noted for species diversity of ladybirds (Coccinellidae) in the pine forest sere. The trend is observed as regards both the potential and actual species diversity as well as with respect to the approximation of the potential diversity in the habitat (Fig. 33).

Inverse tendencies are noted only in soldier beetles (Cantharidae), where the actual species diversity in young stands is quite high, reaching a maximum in the pole wood and visibly decreasing thereafter (i.e. in mature stands). This http://rcin.org.pl 
group is also characterised by a decrease in Pielou's index $(\mathrm{J})$ in the consecutive stages of the pine forest sere (Fig. 33).

Species diversity in aphidophages may behave according to one of three patterns in the pine forest sere. In ladybirds (Coccinellidae), there is an increase (Fig. 34) both in actual diversity and the degree of approximation of the habitat potential. A reverse trend is seen in neuropterans (Neuropteroidea) and aphidophagous digger wasps (Sphecidae). In aphidophagous syrphids (Syrphidae). however, both actual and potential species diversity reaches a maximum in the pole wood stage, but the degree of approximation of the potential diversity is the lowest here.
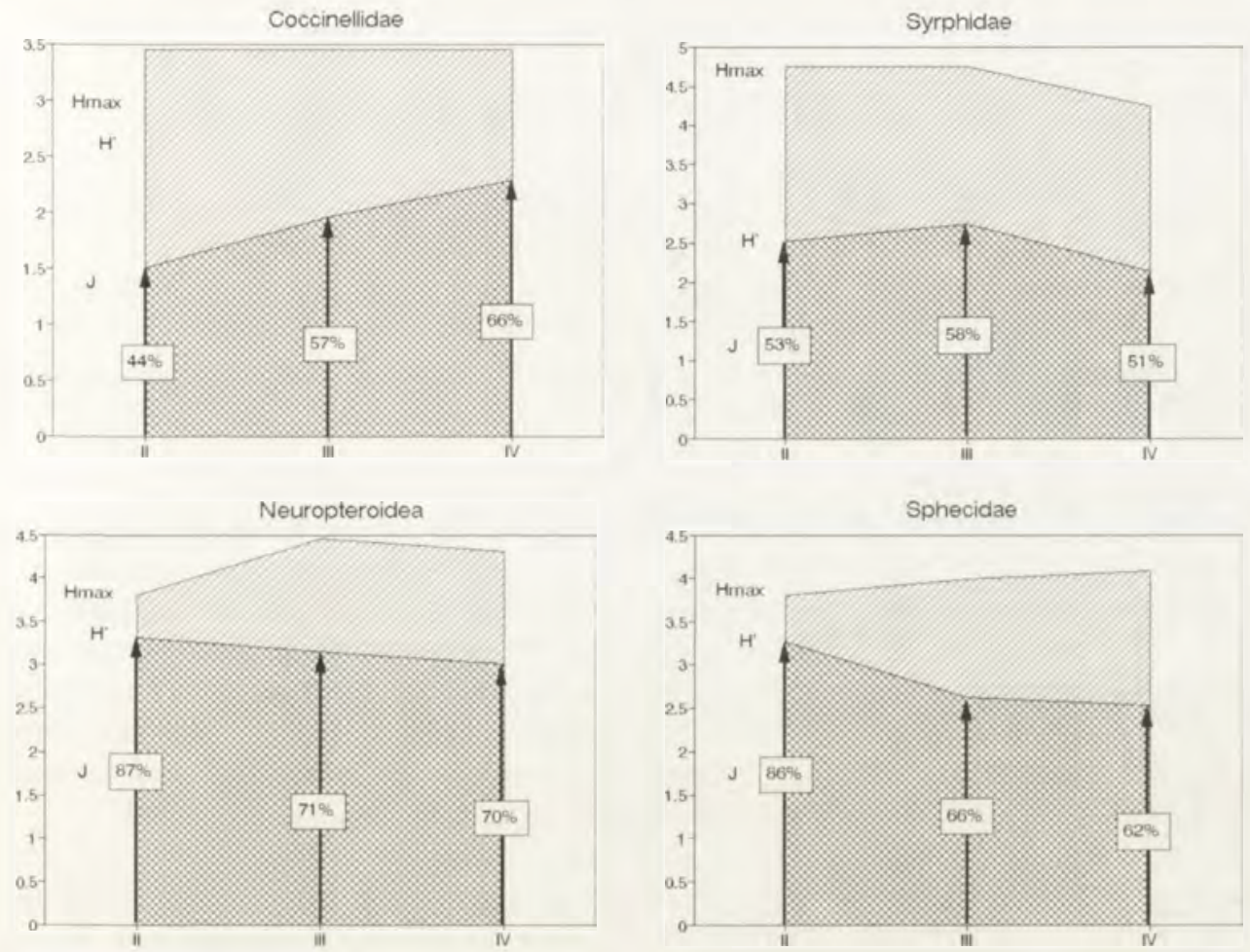

Fig. 34. Changes in actual $\left(\mathrm{H}^{\prime}\right)$ and potential $\left(\mathrm{H}_{\max }\right)$ species diversity in communities of aphidophages and the degree of realisation $(\mathrm{J})$ of potential diversity of the communities in the sere of the pine forest

\subsubsection{Parasitoids of phytophages}

Apart from predators, parasitoids whose larvae present parasitic or semiparasitic mode of life play an important role in reducing the abundance of phytophages. Three groups of parasitoids are particularly important in ecosystems: tachinid flies (Tachinidae), ichneumon flies (Ichneumonidae) and Pipunculidae. They will be described successively. 


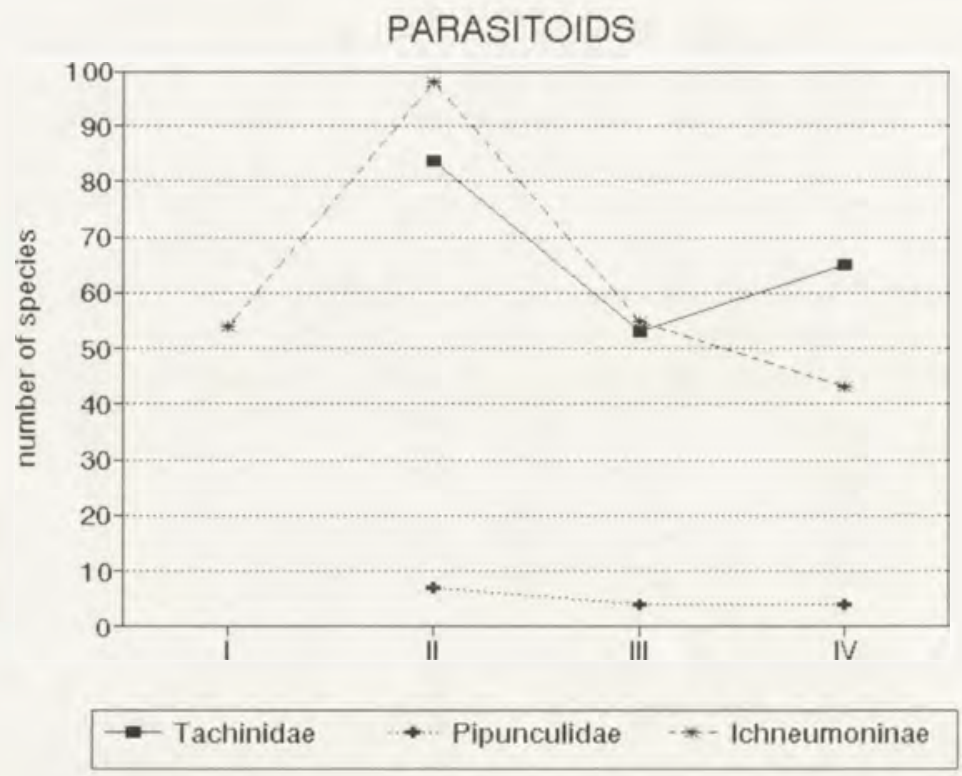

Fig. 35. Changes in the number of species of parasitoids in pine forests of three age classes of the forest stand

Tachinid flies (Tachinidae)

In the pine forests of Puszcza Białowieska tachinid flies are represented by 114 species (DRABER-MONKKO unpublished data). Most of them (82 species) are parasites of lepidopterans (Lepidoptera). Other groups given in the order of decreasing abundance include parasites of beetles (Coleoptera). mostly phytophagous forms (12 species), parasites of sawflies (Symphyta) (7 species). Groups of tachinid flies parasitic on orthopterans (Orthoptera), dipterans (Diptera), heteropteran bugs (Heteroptera), centipedes (Chilopoda) and earwigs (Dermaptera) are less abundant, including no more than 5 species each.

The highest number of tachinid species is recorded in young stands (Fig. 35). This is due to the higher proportion of flowering plants than in older stands. Their nectar is essential for the development of gonads of tachinid flies. Young stands also harbour their hosts: numerous phytophagous species not associated with older stands. The lowest number of tachinid species was recorded for the pole wood, while it was a little higher in mature forests. Tachinid abundance follows a similar pattern with the lowest values in the pole wood (Fig. 36). It is interesting to note that the number of species of Tachinidae parasitic on butterflies, so high in young stands (65), becomes stabilised in older stands (42 species). Fluctuations of abundance in the course of the sere are observed in other host groups of tachinid flies. The number of species estimated on the basis of the lognormal distribution indicates complete convergence with empirical data in each of the three age classes of forest stands. 


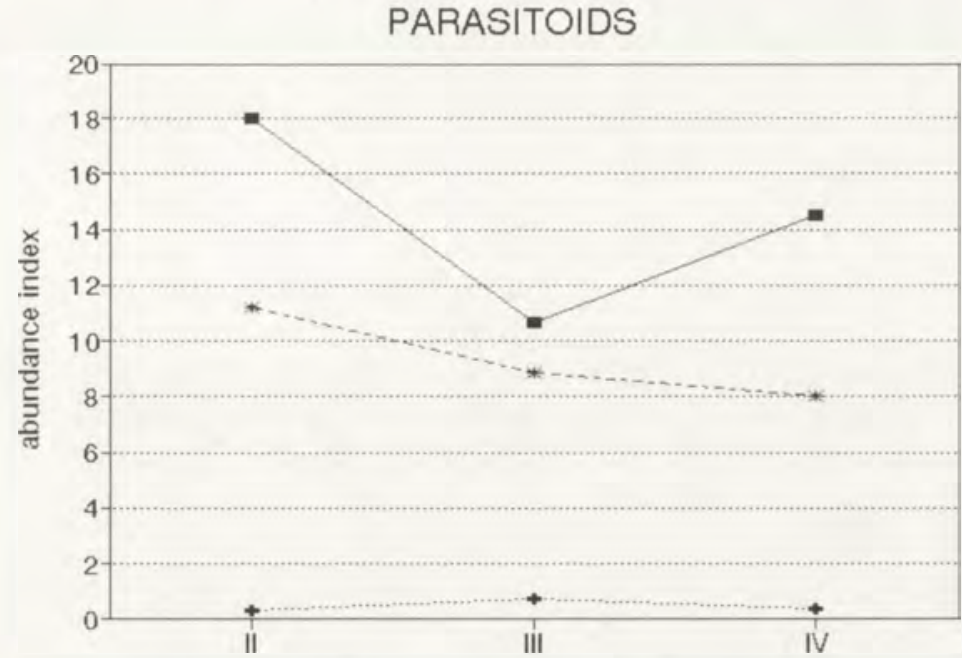

Tachinidae

+*Pipunculidae

*- Ichneumoninae

Fig. 36. Changes in the abundance of parasitoids in pine forests of three age classes of the forest stand

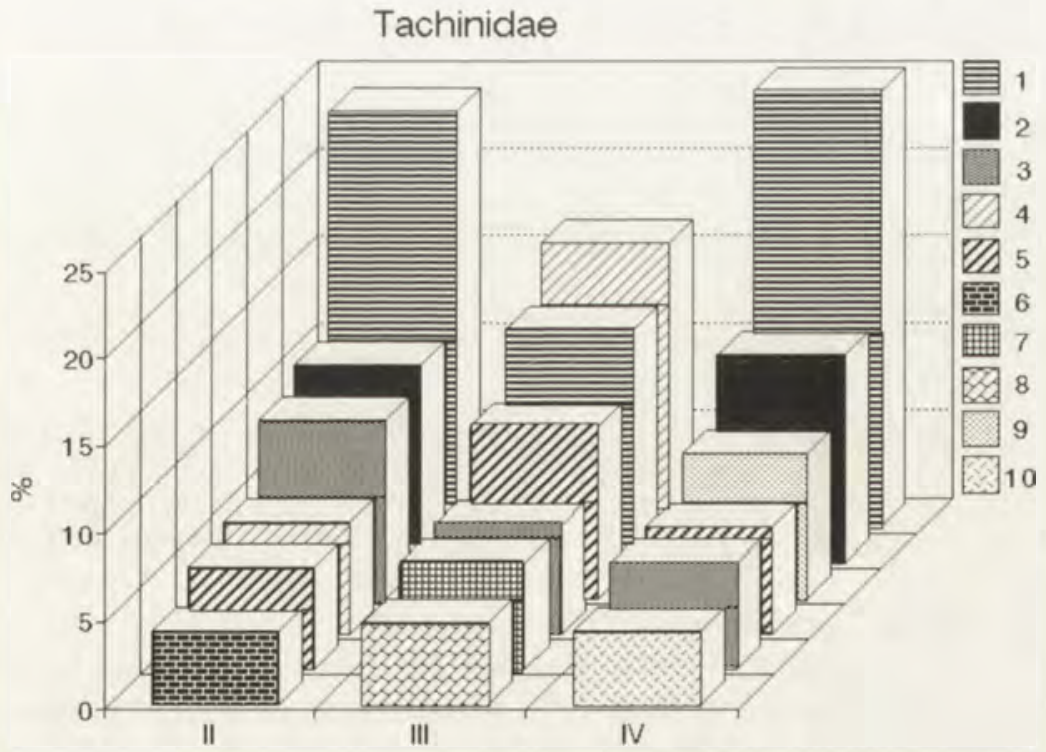

Fig. 37. Dominance structure of communities of tachinid flies (Tachinidae) in forest stands of various ages in Puszcza Białowieska; 1 - Medina separata, 2 - Carcelia bombylans, 3 - Lypha dubia, 4 Ernestia rudis, 5 -Campylochaeta inepta, 6 -Eloceria delecta, 7 -Ceranthia abdominalis, 8 -Peribaea fissicornis, 9 - Triarthria septipennis, 10 - Blepharomyia angustifrons 
The structure of dominance of tachinid fly communities (Fig. 37) is of the dominant-type with a considerable overlap between the community of the young and mature stand. Melina separata. Coralia bombylans, Lypha dubia and Campylochaeta inepta are dominant in both stages. In the pole wood, the top position in the dominance structure is occupied by Ernestia rudis, while the other dominants occupy the second and farther positions.

The species diversity of tachinid flies in the three stages of secondary succession of the pine forest is nearly identical and quite high (Fig. 38) - a little more than 4.5. The degree of approximation of potential species diversity of tachinid flies by the actual values is also similar in all the age classes of the forest stand (the highest in pole wood, the lowest in young stands).
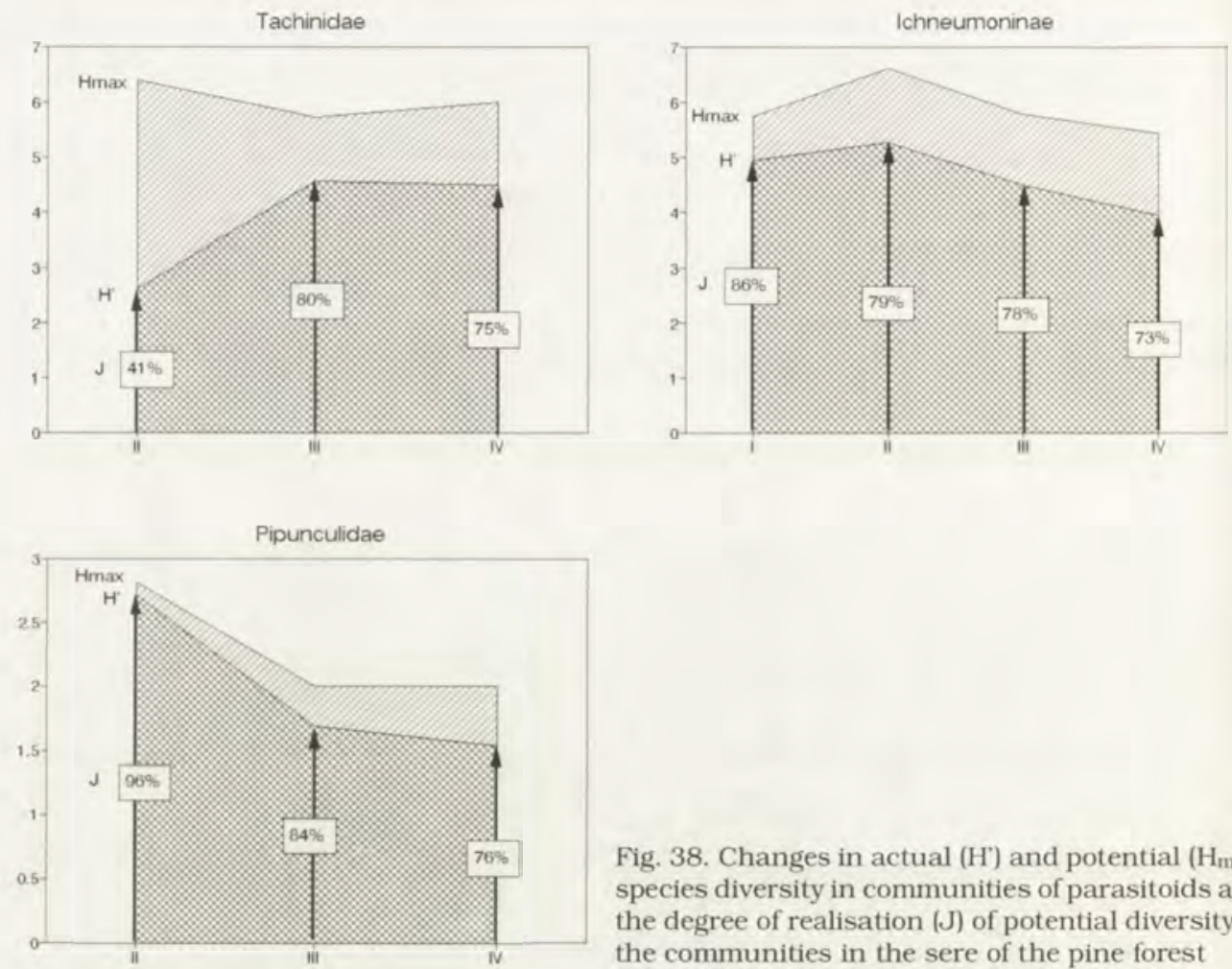

Fig. 38. Changes in actual $(\mathrm{H})$ and potential $\left(\mathrm{H}_{\max }\right)$ species diversity in communities of parasitoids and the degree of realisation $(\mathrm{J})$ of potential diversity of the communities in the sere of the pine forest

Ichneumon flies (Ichneumonidae)

In the present paper ichneumon flies are represented only by parasites of lepidopterans (Lepidoptera), thus including forms biologically associated with the most dangerous foliophagous pests of Polish forests.

The number of species in the pine forest sere (Fig. 35) has a maximum in young stands and a minimum in mature stands. The culture stage is inhabited mostly by open area ichneumon flies, while the community from young stands has features related to the ecotone nature of this habitat. There are numerous 
species present in the culture stage and also typical forest species. In older stands, open areas species recede to be replaced by a poorer complex of parasitoids of Microlepidoptera, mainly Rhyacionia buoliana, and species parasitic on the pupae living in the litter (SAwONIEwicz unpublished data).

The abundance of ichneumon flies presents a similar pattern (Fig. 36). It is the lowest in pine cultures, reaches a maximum in young stands to become stabilised in older stands as a community characteristic of the pine forest.

The structure of Ichneumonidae communities occurring in the consecutive stages of the sere in Puszcza Białowieska is similar to that registered in corresponding forest stands in other regions of Poland (Fig. 39). The core of the community is formed of 14 species with Vulgichneumon deceptor being the one species to assume a markedly dominant position but only in the culture stage. The community of ichneumon flies of the culture stage is quite unique. Of the six dominants, there is only one species (Ctenichenumon funereus) which occurs in the young stand as well. It is only in the latter stage that three typically forest species (Aetherus nitidus, E. sawoniewiczi and Tycherus dodecellae) appear and occupy top positions in the structure of dominance. In older stands, the dominant species group is supplemented by three other species to form a stable core of the community.

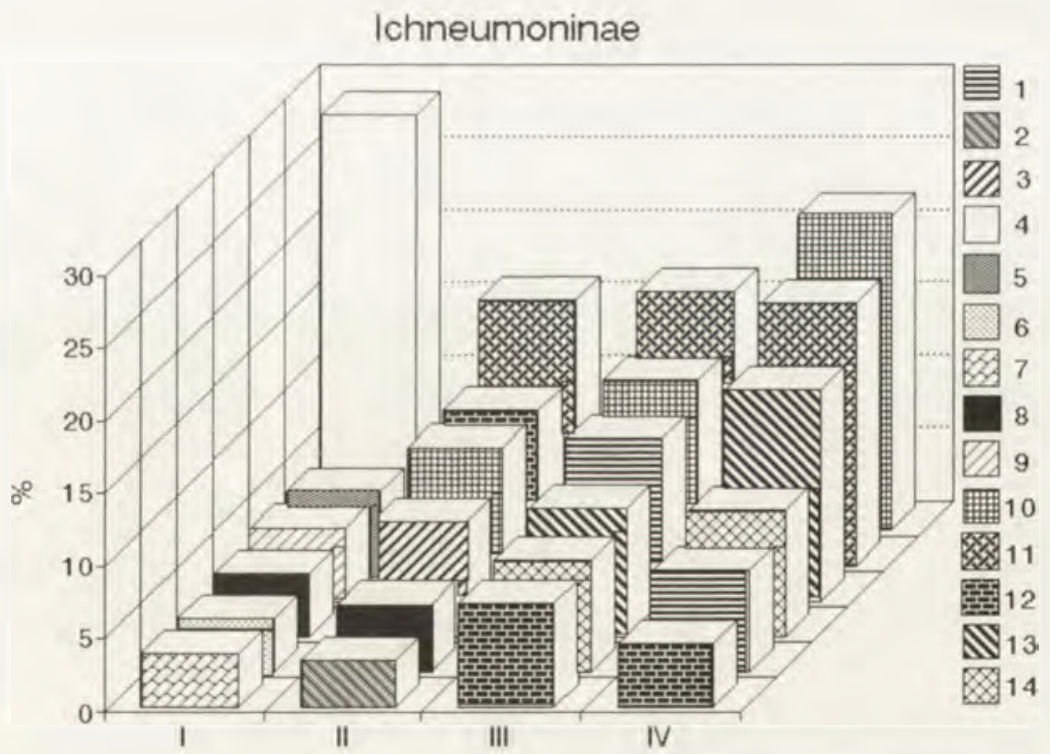

Fig. 39. Dominance structure of communities of ichneumons (Ichneumonidae) in forest stands of various ages in Puszcza Białowieska: 1 - Platylabops virginalis, 2 - Cratichneumon sicarius, 3 Cratichneumon viator, 4 -Vulgichneumon deceptor, 5 -Virgichneumon diagrammus, 6 - Barichneumon plagiarius, 7 - Ichneumon minutorius, 8 - Ctenichneumon funereus, 9 - Eriplatys ardeicollis, 10 Eriplatys sawoniewiczi, 11 - Aetherus nitidus, 12 - Tycheurus dodecellae, 13 - Tycherus vagus, 14 - Tycherus verecundus 
Ichneumonidae species diversity in pine cultures is quite high (Fig. 38), reaching a maximum in young stands which harbour the greatest number of ichneumon fly species. The diversity decreases in older stands to reach a minimum in the mature forest. A similar pattern is reported for potential diversity with a maximum in young stands and a minium in mature stands. The degree of approximation of the potential diversity by the actual diversity decreases in the consecutive stages of the sere. The values of Pielou's index fall from $86 \%$ in cultures to $72 \%$ in mature forest. This is suggestive of the development of internal relations within the community consisting in an increase in the degree of internal organisation at the expense of decreasing species diversity, and the development of a structure of dominance characterised by a more dispersed distribution.

\section{Pipunculidae}

This is a group of small-sized dipterans functioning as specialised parasites of leafhoppers (Homoptera. Auchenorrhyncha). 9 Pipunculidae species occur in the pine forest of Puszcza Białowieska (BANkKOWSKA unpublished data) with the greatest number recorded in young stands (Fig. 35) and only four species occurring in older stands. The abundance of this taxon is lowest in young stands and highest in the pole wood (Fig. 36), decreasing twice in mature forest. With the species composition growing poorer as the stand grows older, species start to appear that are restricted to older stands (Pipunculus spinipes and Chalarus fimbriatus). However, their association with older stands needs to be confirmed

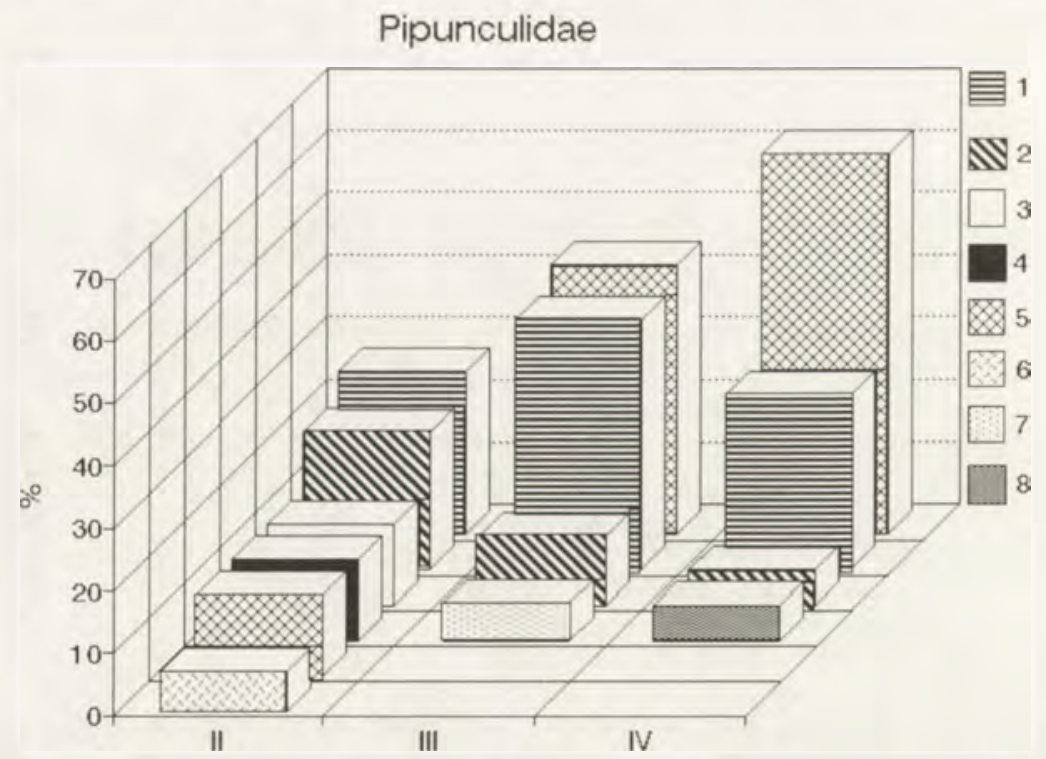

Fig. 40. Dominance structure of communities of parasitic Pipunculidae in forest stands of various ages in Puszcza Bialowieska; 1 - Nephrocerus scutellatus, 2 - Eudorylas subfascipes, 3 Tomosvariella sylvatica, 4 -Cephalops semifumosus, 5 -Verrallia villosa, 6 -Cephalops aenus, 7 Pipunculus spinipes, 8 - Chalarus fimbriatus 
on the basis of a more sizeable material. The dominant role in the community is played by Nephrocerus scutellatus and Verralia villosa, which occur throughout the sere and may be considered dominant species (Fig. 40).

Species diversity tends to decrease throughout the sere (Fig. 38), from a maximum in young stands to a minimum in mature forest. The values of Pielou index also exhibit that trend. This suggests an even abundance distribution of species inhabiting young stands of pine. In the subsequent succession stages, a transformation takes place in the community of Pipunculidae to result in a dominance-type community, the number of species decreases and differences in their proportions become sharper.

\subsection{Secondary succession in the saprotrophic subsystem}

The subsystem of saprotrophs is associated with dead organic matter produced within the ecosystem. Deposited as organic sediments on the surface of soil, it becomes a source of energy and minerals for the complex subsystem of saprotrophs. Owing to this subsystem, organic matter is broken down, and the organic substances it contains are recycled in the ecosystem. Another important product of saprotroph activity is soil. Its surface layers are composed largely of materials processed by the subsystem of saprotrophs. Thanks to them. the soil has a definite structure and type of humus. The subsystem is composed of saprophages, omnivorous animals (pantophages) and predators.

Starting a pine culture on a pine clearing accelerates pine forest succession. In the first period, the soil is considerably degraded, which is accompanied by complete changes in the living conditions of animals living there. This is caused by the removal of the surface cover of the soil, strong insolation, increases in temperature amplitude and changes in moisture relations. The typical crumb-and-pore structure disappears and nutrients are leached leading to drastic impoverishment of the habitat. As the culture grows, secondary succession of plants brings about significant changes in soil conditions and in the rate of decomposition. Insolation decreases causing changes in moisture and thermal conditions, and soil receives more and more nutrients from falling needles, leaves, plants of the ground cover and dead roots. All these factors promote the development of microflora. mainly fungi so that favourable conditions are created for the formation of humus and development of soil animals. As the stand grows, it becomes thinned, the understorey develops and microclimate changes, also affecting soil conditions and the fauna inhabiting that part of the ecosystem. As a result of succession, mesotrophic pine forest develops with moder/mor type of humus possessing features of edaphic climax.

\subsubsection{Soil saprophages}

Saprophages participating in organic matter decomposition are represented by a large group of animals of diverse trophism. An important role in soil formation in pine forests is played by small soil animals such as enchytraeids (Enchytraeidae), mites (Acari), springtails (Collembola) and nematodes (Nematoda). The fauna is classified as soil saprophages feeding on detritus together with bacteria and fungi. It stimulates the microflora. 


\section{SAPROPHAGES}

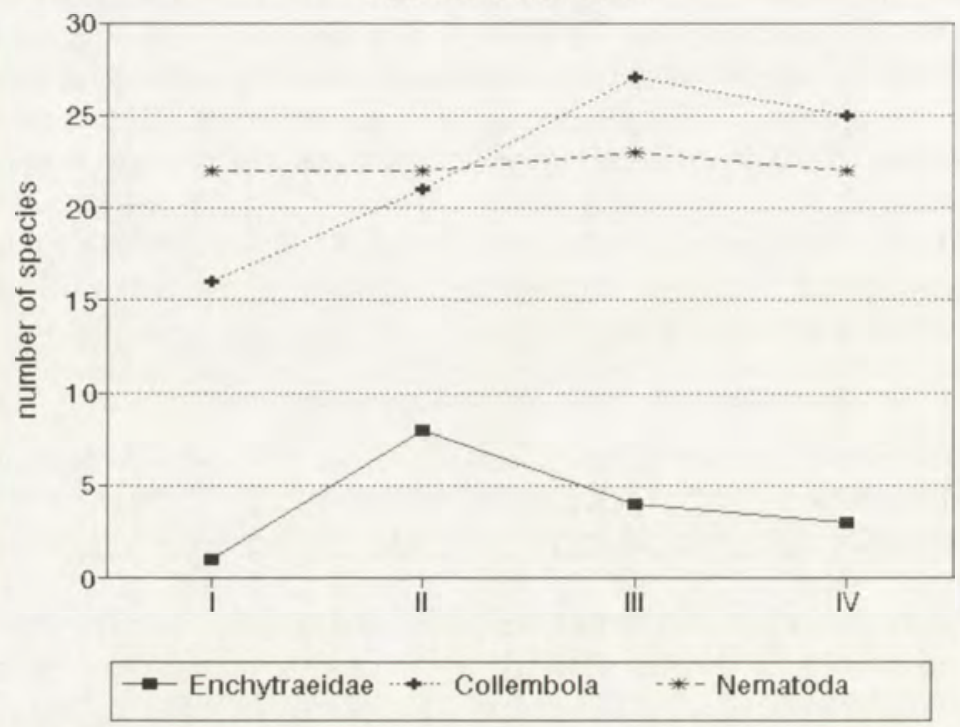

Fig. 41. Changes in the number of species of soil saprophages in pine forests of three age classes of the forest stand

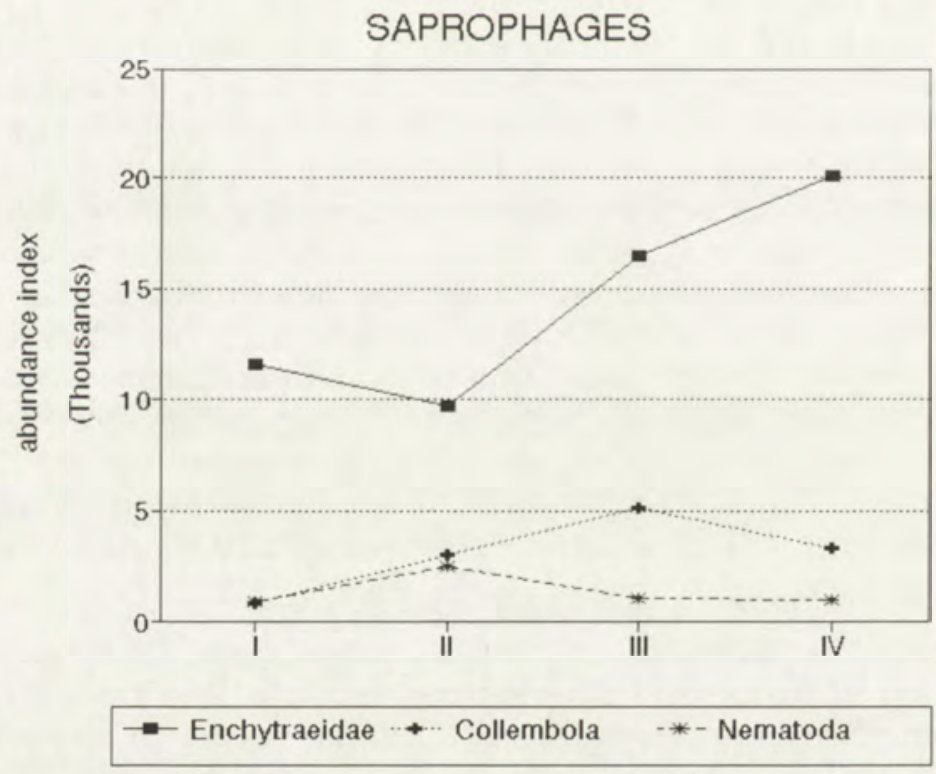

Fig. 42. Changes in the abundance of soil saprophages in pine forests of three age classes of the forest stand 
Due to changes in soil conditions observed in the course of succession and the stand growing older, changes occur also in the communities of animals inhabiting the stand (species composition, abundance and structure of dominance). The analysis of transformation of communities of selected soil saprophages (Nematoda. Enchytraeidae, Collembola) in pine forests of various age allows to track the progress of succession.

Studies of the effect of secondary succession on mesofaunal communities, including communities of soil saprophages, are more frequently concerned open areas (meadows, field) than with forests (KOEHLER, BORN, 1989: PETERSEN, KROGH, 1987). In pine forests, investigations of communities of soil mesofauna in forest plantations of various age have been carried out by LoHM et al. (1977).

\section{Nematodes (Nematoda)}

Nematodes occupy a special position among organisms participating in the secondary succession of pine forest. The number of species (Fig. 41) is not subject to changes during ecosystem transformations, with 22 species present. More considerable changes are observed in abundance of nematodes. The initial stage of succession is associated with an abundance minimum, while in young stands Nematoda achieve a maximum of abundance, exceeding the minimum nearly 3 times. In older stands the abundance becomes stable. However, in comparison to abundance changes in springtails and Enchytraeidae (Fig. 42). fluctuations in the abundance of nematodes may be considered insignificant. The pattern of changes in abundance is related to a decrease in insolation and

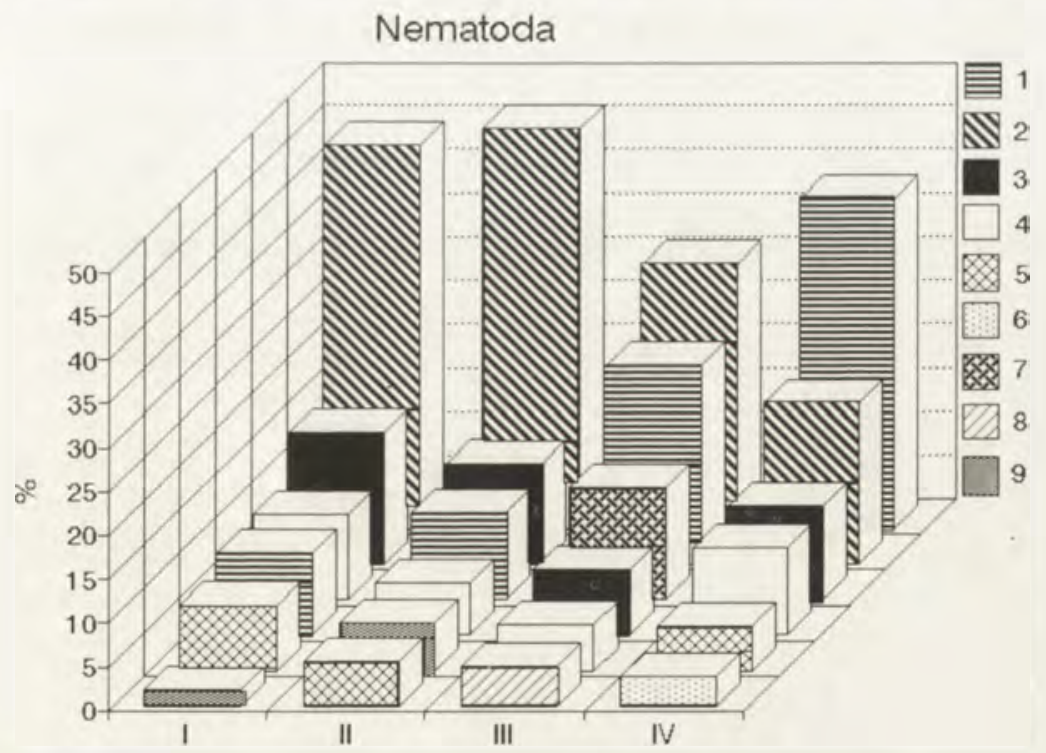

Fig. 43. Dominance structure of communities of nematodes (Nematoda) in forest stands of various ages in Puszcza Białowieska: 1 - Filenchus ditissimus, 2 - Acrobeloides nanus, 3 - Aphelenchoides spp. . 4 -Plectus pusteri, 5 -Wilsonema olophorum, 6-Teratocephalus dadayi, 7 - Ypsylonellus insubricus, 8 - Eudorylaimus silvaticus, 9 -Rhabditis s. $l$. 
denser forest floor cover associated with succession, which results in smaller variations in soil moisture.

The structure of dominance in soil Nematoda communities is similar in the four succession stages (Fig. 43). The core of the community does not change, there are small changes in the dominant species group. Greater transformations are noted in the structure of less numerous species. As the stand grows older, the contribution of fungivorous nematodes increases while that of bacteriophagous Nematoda decreases, which is associated with an increase of the share of fungi in the forest floor microflora (BRZESKI unpublished data).

The species diversity of nematodes undergoes similar stabilisation, as the parameters discussed above (Fig. 44). The value of the diversity index $\left(\mathrm{H}^{\prime}\right)$ fluctuates around 3.0. Additionally, potential species diversity $\mathrm{H}_{\max }$ in the consecutive stages nears 4.5 so that the degree of approximation of potential diversity does not change considerably.
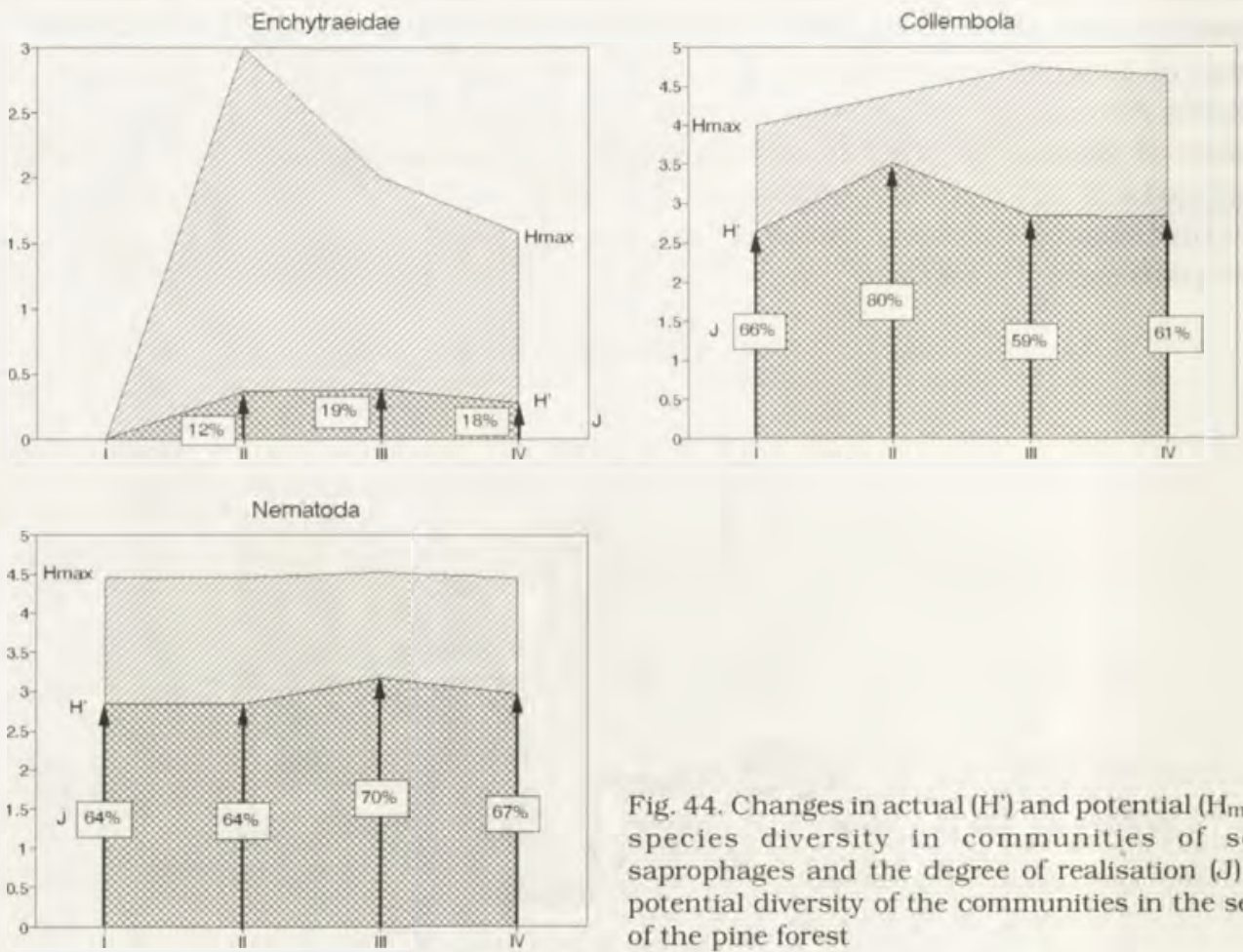

Fig. 44. Changes in actual $\left(\mathrm{H}^{\prime}\right)$ and potential $\left(\mathrm{H}_{\max }\right)$ species diversity in communities of soil saprophages and the degree of realisation (J) of potential diversity of the communities in the sere of the pine forest

Enchytraeids (Enchytraeidae)

Enchytraeid communities in the soil of pine forests of Puszcza Białowieska are poor in the number of species, with one dominant species, namely Cognettia sphagnetorum. In the initial stage of succession (culture), where the soil is most degraded, only one species was recorded. The greatest number of species was registered in the young stand. In older stands their number decreases (Fig. 41). 
approaching the number characteristic of mature forests in other forest complexes in Poland (PILIPIUK 1993). Community abundance in cultures and young stands is lower than in the pole wood stage and mature forests, where it reaches a maximum (Fig. 42 ).

The structure of the enchytraeid community (Fig. 45) is characterised by a marked dominance of one species in every stage of succession. Cognettia sphagnetorum accounts for more than $90 \%$ of the community throughout the sere, reaching a maximum in the pole wood to undergo a slight fall in the mature stand. If we ignore the restricting character of the culture stage where only one enchytraeid species is present, the young stand is capable of accommodating seven other accessory species. In the subsequent stages the structure of the community becomes poorer due to elimination of accessory species (PILIPIUK unpublished data).

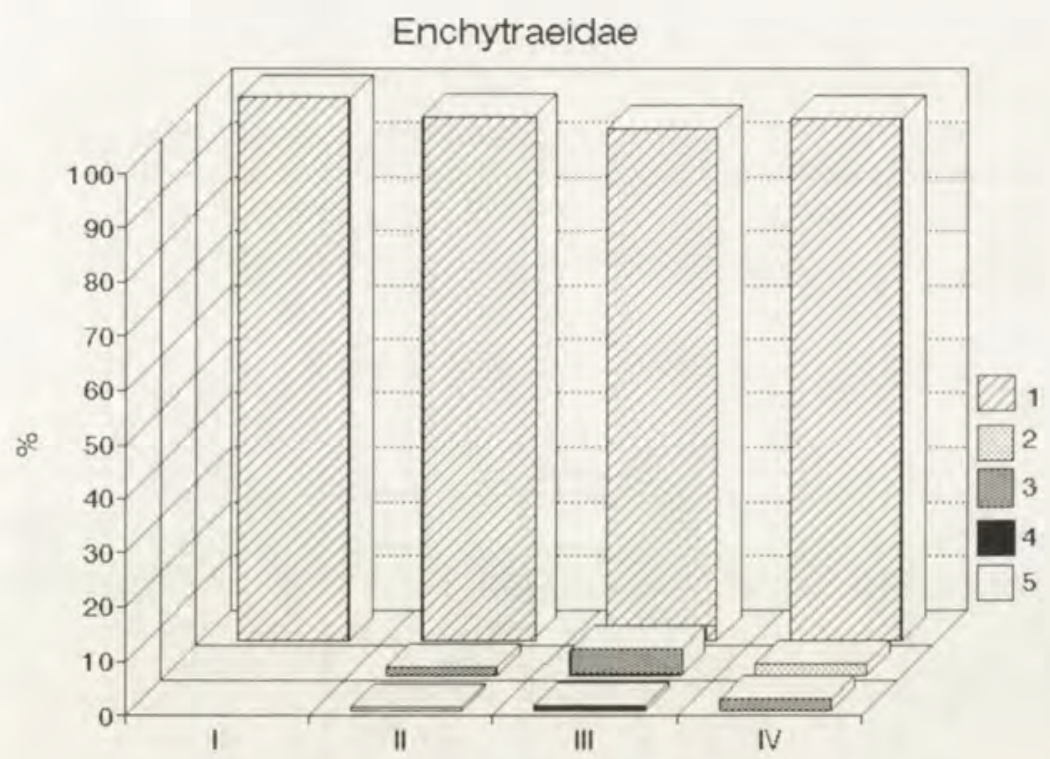

Fig. 45. Dominance structure of communities of Enchytraeidae in forest stands of various ages in Puszcza Bialowieska; 1 - Cognettia sphagnetorum. 2 -Achaeta sp. , 3 -Mesenchytraeus sp. . 4 Marionina sp. . 5 - Buchholzia simplex

The species diversity of enchytraeids is profoundly influenced by structural relations (Fig. 44). Actual diversity $\left(\mathrm{H}^{\prime}\right)$, equalling 0 in the first stage of succession, never exceeds 0.5 in the subsequent stages. Greater changes occur with respect to potential diversity $\left(\mathrm{H}_{\max }\right)$. It reaches a peak in the young stand to fall considerably in older stands. The utilisation of the potential habitat capacity to increase the diversity of the community of enchytraeids is low, never reaching $20 \%$ in the entire sere. 


\section{Springtails (Collembola)}

The number of species of these animals in the pine forest sere tends to increase (Fig. 41). It reaches a maximum in the pole wood to fall slightly in the mature stand. A similar pattern is observed in abundance of springtails (Fig. 42), which is much lower than that of enchytraeids, while being slightly higher than the abundance of nematodes.

The species composition of Collembola differs considerably in the consecutive stages of the pine forest sere in Puszcza Białowieska (Fig. 46). Convergence of species composition is only observed when comparing communities inhabiting older stands (pole wood and mature forest). There are also differences in the structure of dominance of the springtail communities. In younger stages, there is a decrease in the number of non-abundant species combined with a marked dominance of one species $(80 \%)$. In older age classes (pole wood, mature forest) the core of the community is formed of a number of co-dominant species and the low-share species group is much more numerous. In the consecutive stages of the pine forest sere, species forming the dominant group are replaced by others (STERZYNSKA unpublished data).

Species diversity of springtails (Fig. 44) is on the same level as in nematodes. However, a maximum is reached in the young stand stage, while in older stands actual species diversity $\left(\mathrm{H}^{\prime}\right)$ oscillates around 2.8. Potential diversity reaches a peak in the two age classes. The highest degree of approximation of the potential

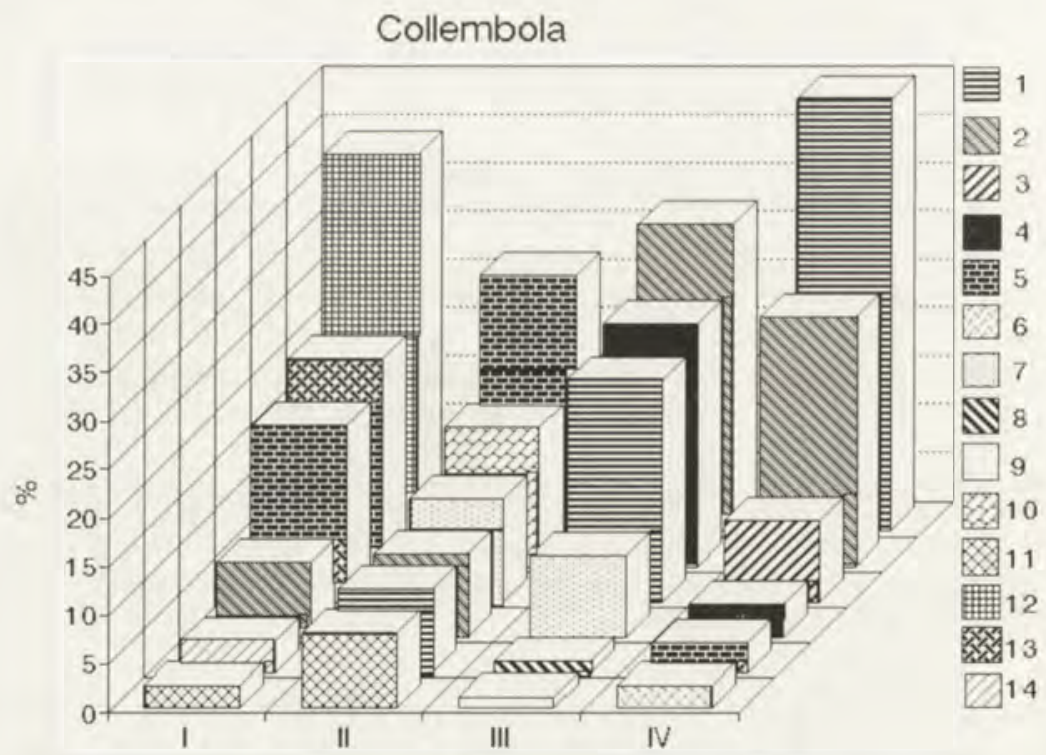

Fig. 46. Dominance structure of communities of springtails (Collembola) in forest stands of various ages in Puszcza Bialowieska: 1 - Pseudosinella zygophora, 2 - Isotomiella minor, 3 - Mesaphorura macrochaeta, 4 - Isotoma notabilis, 5 - Schoetella ununguiculata, 6 - Onychiurus subuliginatus, 7 Isotoma sp. j. . 8 - Folsomia quadrioculata, 9 - Anurophorus septentrionalis, 10 - Entomobryidae sp. j., 11 -Willemia aspinata, 12 -Pogonognathellus flavescens, 13-Anurida pygmaea, 14-Proisotoma minima 
is seen in young stands, while the difference is the greatest in mature forests. The formation of community structure in Collembola is accomplished at the expense of species diversity.

Two models of dominance structure occur in the sere studied. The first of them has the same species of the dominant group forming the core of the community throughout the sere. In this model changes are seen the group of species with lower shares in the community. This model is conformed to by two groups - Nematoda and Enchytraeidae (Fig. 43 and 45). The other model of dominance structure is observed in Collembola (Fig. 46). In this taxon there are considerable transformations in the dominant species group with different species prevailing in young stands and older ones, although one must not speak about complete substitution of species composition. What is more, Collembola communities from older stands have several co-dominants, while only one marked dominant appears in younger stands. Analysis of similarity of the actual communities of soil saprophages to the five theoretical statistical distributions showed that the distribution of species in the communities under study is closest to the negative binomial distribution. The similarity is statistically significant for various groups in various succession stages. In some cases the estimated number of species is higher than the actual one (Collembola) indicating a higher species capacity of the habitat. In others (Enchytraeidae), the estimation corresponds to empirical findings.

Analysis of selected groups of soil saprophages showed that the communities of the groups under study become stabilised in older stands of pine. The communities of these animals inhabiting middle age class stands present a "preparatory stage" for the formation of communities characteristic of natural mature pine forests.

In the sere under investigation, the pole wood is a stage of greater potential for realizing species diversity in relation to communities from mature stands. In mature stands, where habitat conditions become stabilized to a certain extent, species diversity of soil saprophages is lower. GILLER (1984) claims a link between the degree of species diversity and habitat heterogeneity. In the sere studied, an increase in habitat heterogeneity is stimulated by the development of the layer structure of the stand and changes in soil conditions. Stratification, both horizontal and vertical, provides many new niches. Particularly important for saprophages are litter and humus. The relations between soil saprophage communities and the type of humus formed are described by PONGE (1993). Species diversity may also rise with increasing production of food such as fungi and microorganisms and organic matter content in the soil (PIANKA 1966). In mature climax ecosystems, productivity often decreases or remains constant. Species diversity also may fall in such ecosystems due to the rising number of interdependencies between organisms even though it is still stimulated by the growing number of niches. The mature pine forest is a mature ecosystem where habitat conditions become stabilized. The decrease in the species diversity of soil saprophages, which can be observed in the mature forest is connected above all else to the stabilization of the rate of humus fixation and of humus type. 


\subsubsection{Pantophages and soil predators}

An important role in regulating the abundance of the saprophage subsystem is played by omnivorous and predatory animals. The former are represented in the pine forests by ants, which control the whole ecosystem feeding on a wide range of animal and plant foods. Two families of dipterans (Rhagionidae and Therevidae) serve as examples of soil predators. The limbless larvae of these dipterans penetrate into the soil habitat hunting small invertebrates.

\section{Soil pantophages}

Ants (Formicidae)

Ants play a particular role among the many groups of pantophagous soil invertebrates. Due to their high abundance and exceptional biological activity, they are a functional group vital to maintaining homoeostasis in forest ecosystems, particularly in coniferous forests (KARPIŃSKI 1956, KACZMAREK 1963). More or less closely associated with this habitat are about 30 species of ants of the nearly 80 species forming the Polish ant fauna (PISARSKI 1975, CZECHOWSKI unpublished data). Their role in soil formation consists in supplementing the soil with organic compounds and shaping the composition of the microflora (PETAL 1977). It is also closely linked with the changes occurring during succession.

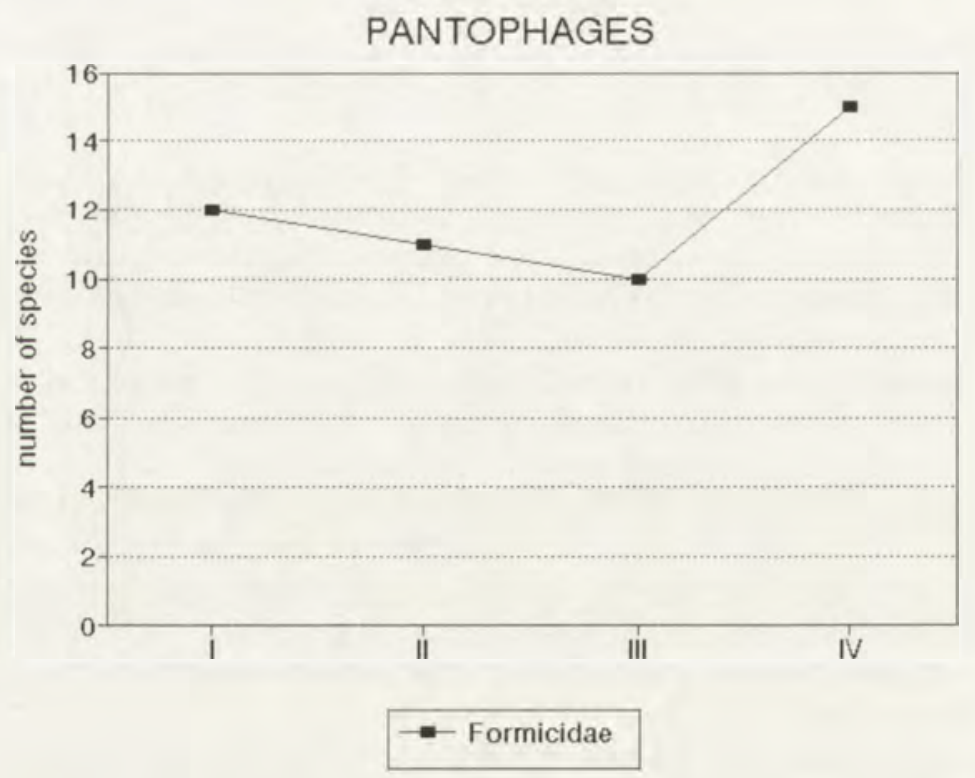

Fig. 47. Changes in the number of species of ants in the secondary sere of pine forests

Only 19 species of ants are associated with the pine forest in Puszcza Białowieska. 12 species inhabit the culture stage (Fig. 47). In the young stand http://rcin.org.pl 
and pole wood their number decreases slightly to reach a maximum in the mature forest. During the secondary succession of the pine forests of Puszcza Bialowieska substantial changes take place in the composition and structure of the ant community (CECHOWSKI unpublished data). The succession in the Formicidae taxocoene consists of two phases. The first of them is observed in young stands and the pole wood. The two communities bear a $70 \%$ species composition similarity (according to Søerensen's index) and identical structures of dominance (Morisita's index $=1$ ). The most abundant species in these communities are polytopic species of dry habitats (Fig. 48), and the xerothermophilous Tetramorium caespitum was a dominant in both communities ( $64 \%$ on the average), while Lasius niger, a ubiquitous, typically pioneering species, was a subdominant $(25 \%)$. Communities from the maturing and mature stands formed the second phase of succession with a similar degree of species composition similarity $(70 \%)$ and similar structures of dominance (0.95). The most abundant species in that phase included polytopes of wet habitats with the dominant Myrmica ruginodis (59\%). In terms of the number of ant nests, the second position was occupied by the forest oligotope Leptothorax acervorum (24\%). Formicidae communities of the two distinct succession phases differed not so much in species composition (average similarity 66\%) as in the structure of dominance (average similarity as low as 0.07 ).

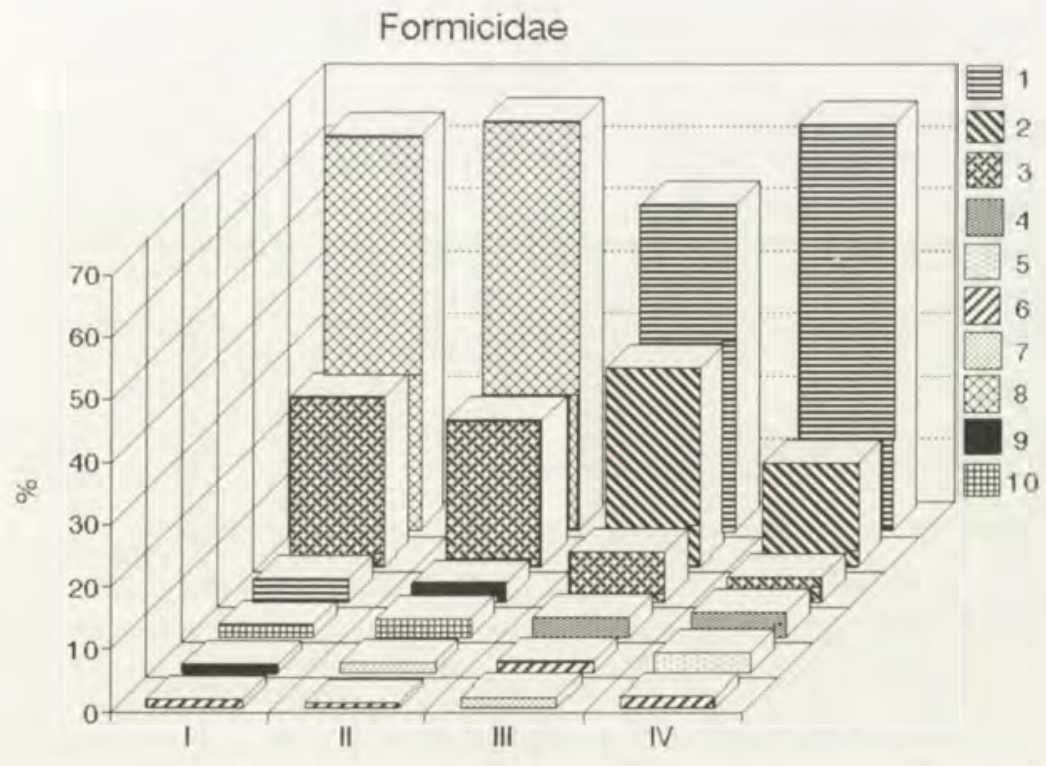

Fig. 48. Dominance structure of communities of ants (Formicidae) in forest stands of various ages in Puszcza Białowieska; 1 -Myrmica ruginodis, 2 -Leptothorax acervorum, 3 -Lasius niger, 4 - Lasius umbratus, 5 - Leptothorax muscorum. 6 - Lasius flavus, 7 - Myrmica lobicornis, 8 - Tetramorium caespitum, 9-Myrmica schencki, 10 - Formica fusca 
Changes in total density of ant nests were observed in the Formicidae communities of the pine forest sere (Fig. 49). This parameter is subject to substantial variations in consecutive stages to finally reach a value (in mature forests) similar to that recorded for the earliest stage studied (pine culture).

Actual species diversity $\left(\mathrm{H}^{\prime}\right)$ measured with Shannon-Weaver's index exhibits a gentle but steady increase with the growing age of the forest stand: from 1.52 to 1.77 (Fig. 50). Potential diversity $\left(\mathrm{H}_{\max }\right)$ is also the highest in the mature stand stage (3.91) but the transitional stages are characterised by slightly lower values (3.32-3.58). The degree of approximation of the potential does not exhibit considerable changes either (Fig. 50), being, however, the lowest in the initial stages of succession $(42 \%$ and $45 \%$ in the culture and young stand stage respectively) to grow slightly in the older stages (53\% and $74 \%$ in the maturing stand and mature forest respectively).

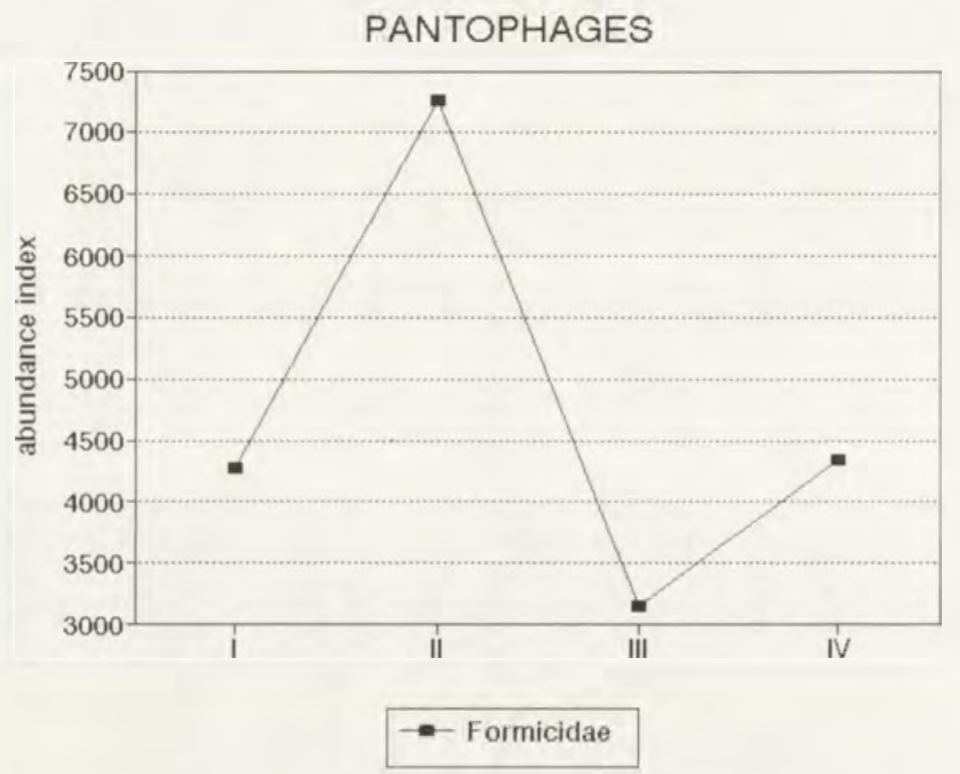

Fig. 49. Changes in the abundance of ant nests in relation to the age of pine forest stands

The specific features of the secondary succession taking place in the plots of pine forest distributed in a relatively "patchy" manner and going through various stages of maturity, include the presence of the forest ant species of the subgenus Formica s. str. in every succession stage, especially in the cultures, the species itself being only typical of the climax stages in forests. They represent the K-type ecological strategy i.e. conquer their environment slowly but remain there forever (PISARSKI, CZECHOWSKI 1994). Under the circumstances of the large forest complex of Puszcza Białowieska, large colonies of these ants are able to survive forest felling and silvicultural practices leading to the establishment of a http://rcin.org.pl 
plantation, and to maintain their nests by feeding in adjacent old stands. A spectacular example was the complete absence of anthills of Formica polyctena in one of the mature forest areas studied, although the species had a high share in the material obtained using Barber's pitfall traps (CZECHOWSKI unpublished data).

\section{Formicidae}

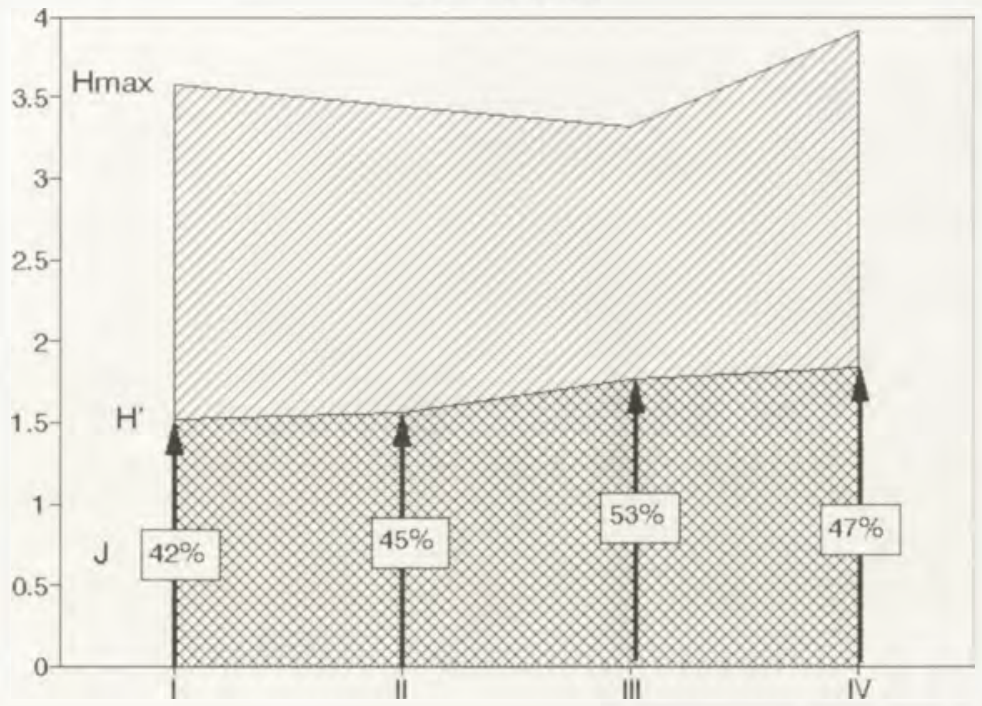

Fig. 50. Changes in actual $\left(\mathrm{H}^{\prime}\right)$ and potential $\left(\mathrm{H}_{\max }\right)$ species diversity in communities of ants and the degree of realisation $(\mathrm{J})$ of potential diversity of the communities in the sere of the pine forest

\section{Soil predators}

Out of a number of groups of dipterans whose larvae develop in the soil leading a predatory mode of life, the families Therevidae and Rhagionidae are analysed in our study. The data on their occurrence in Poland in to-date literature are quite scarce (TROJAN 1970. MIKOLAJCZYK 1991), neither has the structure of communities been studied.

\section{Therevidae}

A total of 14 Therevidae species were found in pine forest stands in Puszcza Białowieska based on material collected with Moericke's pitfall traps i.e. imagines (Fig. 51). The abundance of Therevidae and the number of species in three different age classes of the pine forest: young stand, pole wood and mature stand, do not vary significantly (Fig. 52). The communities are quite similar with regard to their species composition (the values of Søerensen's index are $78 \%$, $82 \%$ and $76 \%$ ). Thereva handlirschi is the dominant species at all stages (Fig. 53). 


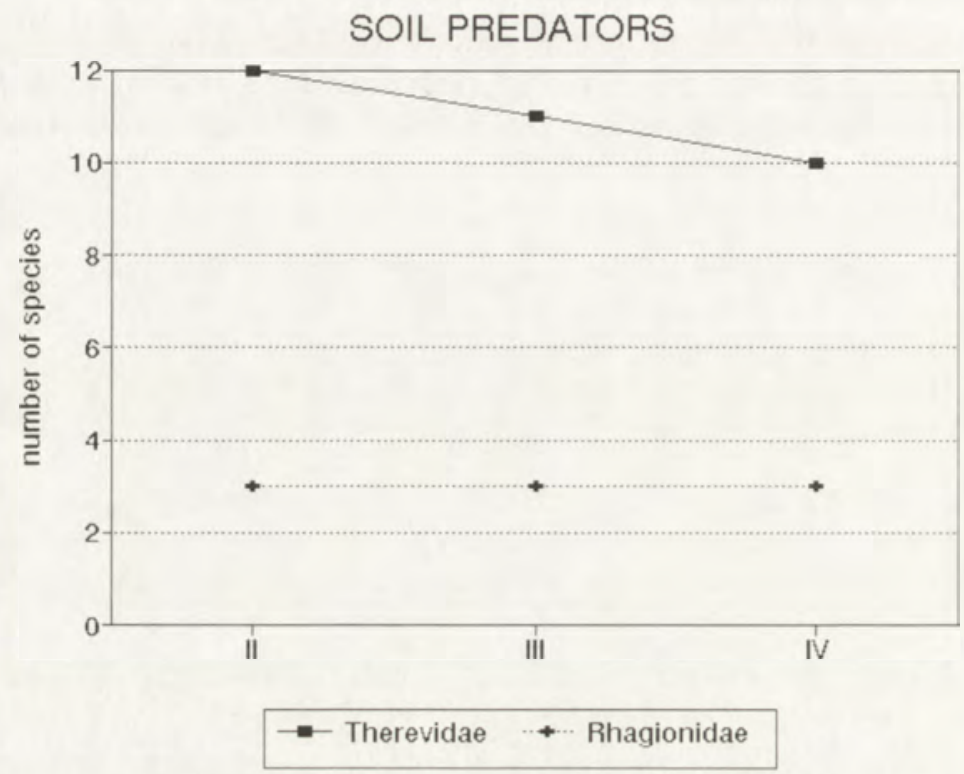

Fig. 51. Changes in the number of species of soil predators in the secondary sere of pine forests

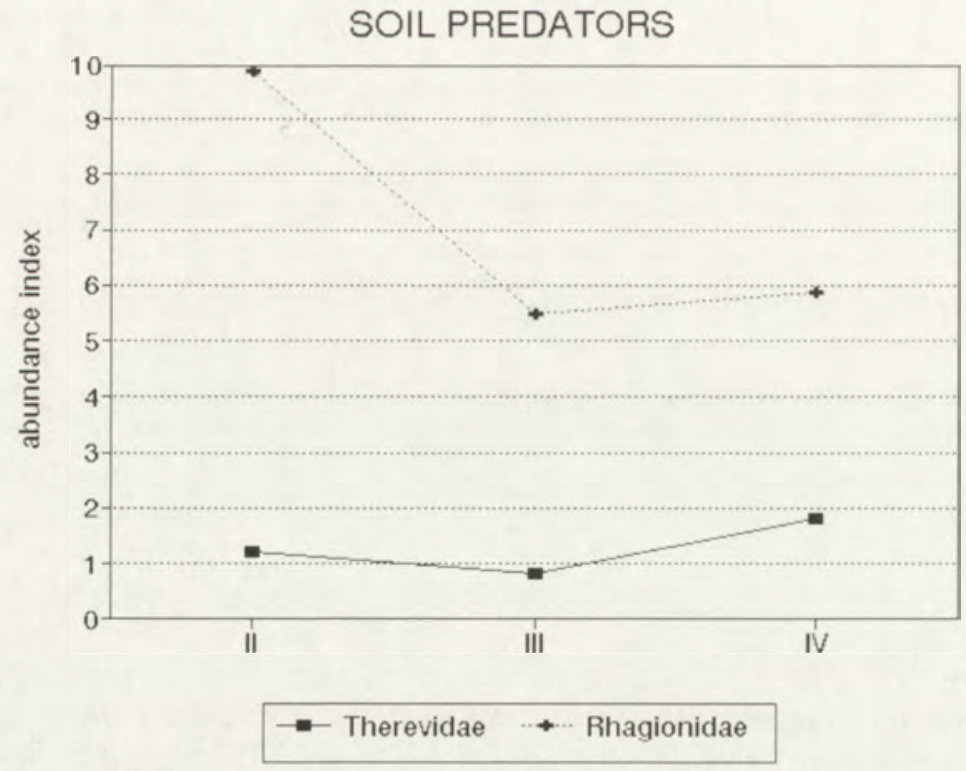

Fig. 52. Changes in the abundance of soil predators in relation to the age of pine forest stands http://rcin.org.pl 
The species occurs commonly throughout the country. The similarity of community structures is also high in Therevidae, achieving values from 0.80 to 0.97 according to Morisita's coefficient. The only difference we have observed between communities of Therevidae in different age classes of the pine forest is that in the young stand the distribution of abundance per species parallels, in all likelihood, three distributions at the same time, namely the geometric series, the logarithmic series and the binomial negative distribution. The degree of similarity to these distributions drops considerably in communities occurring in the pole wood, while Therevidae abundance distribution in the mature forest does not bear any similarity to any of the theoretical distributions considered. The similarity to the geometric series, which indicates, as the theoretical principle has it, that the abundance of each species is proportional to the habitat resources it utilises, suggests that in the case of Therevidae such a situation may actually take place in younger age classes of pine forest. As the stand grows older, the structure of the community probably becomes less regular, which seems easy to understand considering the method of sample collection. In the consecutive stages of the pine forest sere, Moericke's pitfall traps were used to collect insects flying at increasingly high altitudes, possibly resulting in a more random selection of the Therevidae fauna, which might be more closely associated with the ground cover where it is often registered. The slight fall in the actual and potential diversity indices observed in the consecutive stages of the pine forest sere stems from slight variations in the number of species. The

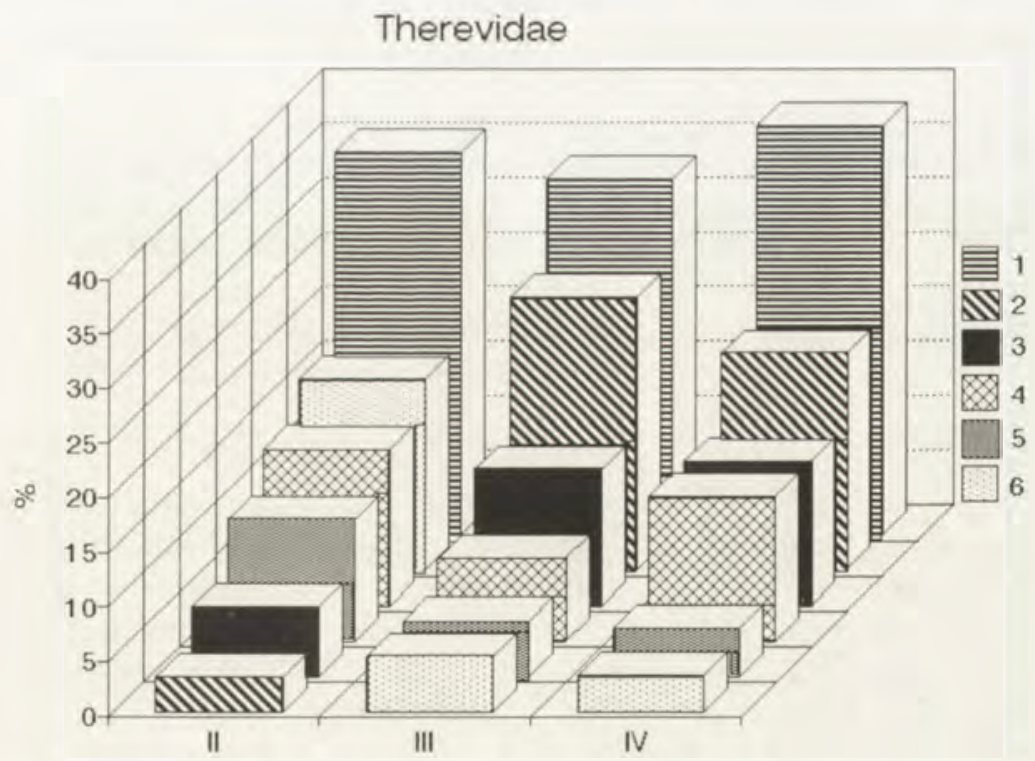

Fig. 53. Dominance structure of communities of Therevidae in forest stands of various ages in Puszcza Białowieska; 1 - Thereva handlirschi, 2 - Thereva nobilitata. 3 - Thereva lanata. 4 - Thereva plebeja, 5 - Thereva circumscripta, 6 - Cliorismia ardea 


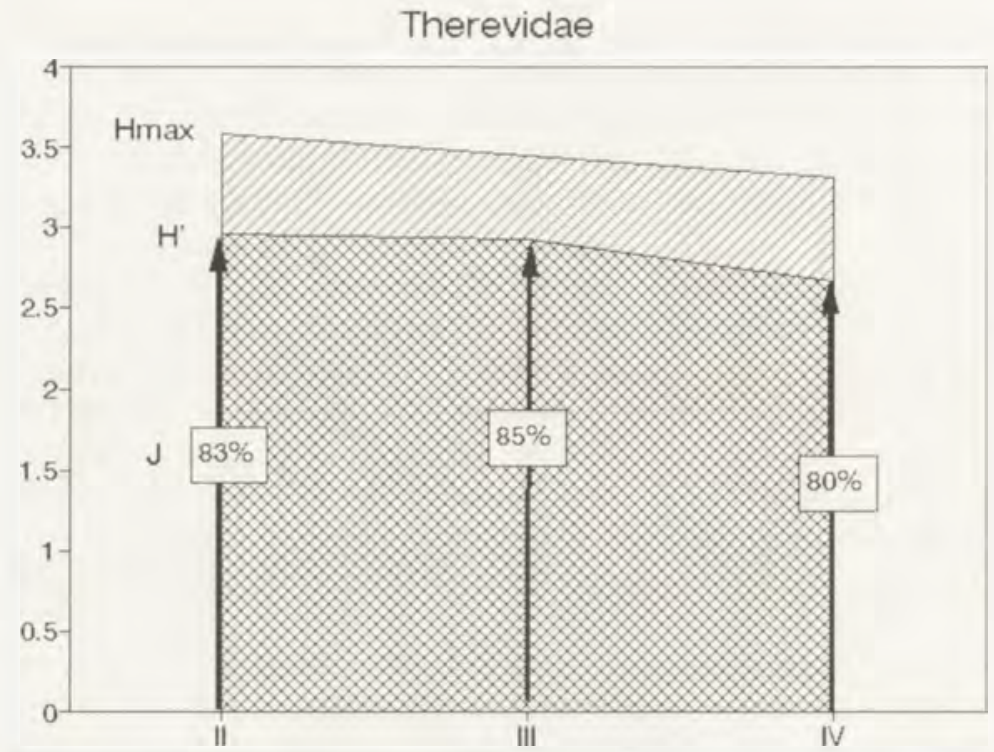

Fig. 54. Changes in actual $\left(\mathrm{H}^{\circ}\right)$ and potential $\left(\mathrm{H}_{\max }\right)$ species diversity in communities of Therevidae and the degree of realisation $(J)$ of potential diversity of the communities in the sere of the pine forest

constant nature of this community parameter is confirmed by the degree of approximation of potential species diversity, which remains at a more or less the same high level ranging from 80.4 to 84.7 (Fig. 54).

\section{Rhagionidae}

Communities of Rhagionidae, dipterans exhibiting, in the larval and imago stages, a predatory mode of life, similar to Therevidae, were also studied in three stages of pine forest in Puszcza Białowieska. These communities exhibited similarly high constancy of the species composition and structure. They are composed of only three species, the common Rhagio lineola being the dominant with at least a $95 \%$ share in each of the communities under study.

\subsection{Vertebrates}

Vertebrates are considerably diversified in species composition, size and the role that individual species play in nature. In ecological terms, they are regarded as belonging to two subsystems. Phytophages, which include hoofed mammals and most rodents, are biotrophs. The other subsystem, macrotrophs, embraces predators controlling the abundance of the biotrophic and saprotrophic subsystems. Special methods are employed for assessing species composition and abundance of vertebrates, depending on the size and mode of life so that vertebrates are seldom mentioned in comprehensive faunal papers, usually dealing only with invertebrates. This analysis is based on a paper by WOŁK and GUTOWSKI (1984) devoted to small mammals and birds of pine forests of Puszcza Białowieska and on studies of small mammals of pine forests (PUCEK http://rcin.org.pl 
unpublished data). Neither of these papers includes large mammals, whether hoofed or predatory, or birds of prey. These groups, however, do not contain groups characteristic of pine forests.

\section{Mammals (Mammalia)}

Small mammals (Micromammalia) encompass two groups performing different biological roles: phytophages, which comprise rodents, and insectivores (some species may be considered polyphagous). 15 species of small mammals were found in the pine forests of Puszcza Białowieska. The number of species in individual stages of secondary succession, the number of species revolves around 10 (Fig. 55). A noticeable decrease in the number of species - down to 7 (PUCEK unpublished data) or 4 (WOEK and GUTOWSKI 1984) - is seen in the most mature stands. These differences turn out to be rather insignificant considering the period when the materials were collected and the species represented by single individuals collected during the five years of catches. These species (see inventory) are regarded as faunal rarities in the area of Puszcza Białowieska.

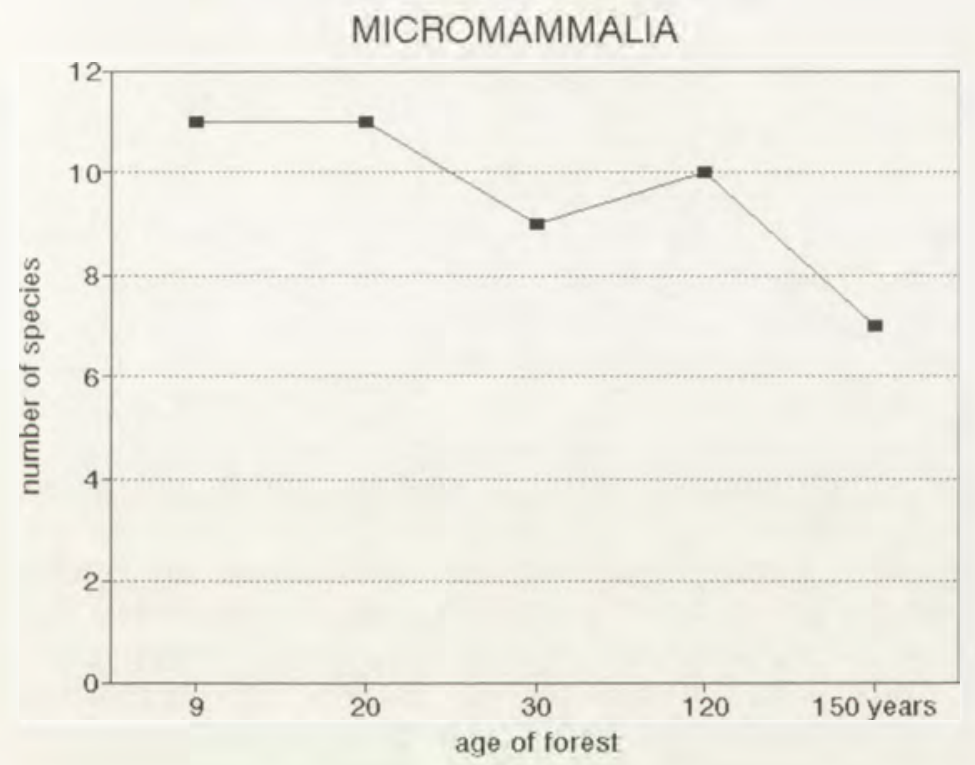

Fig. 55. Changes in the number of species of small mammals in relation to the age of pine forest stands

The pattern of changes in abundance is characterised by a high density of small mammals in pine cultures (Fig. 56). There is a 30\% fall in young stands and the pole wood, and in mature forest the abundance of Micromammalia returns to the original values.

The structure of the small mammal community shows a stable group of dominants throughout the secondary sere (Fig. 57). It is formed of four species, 


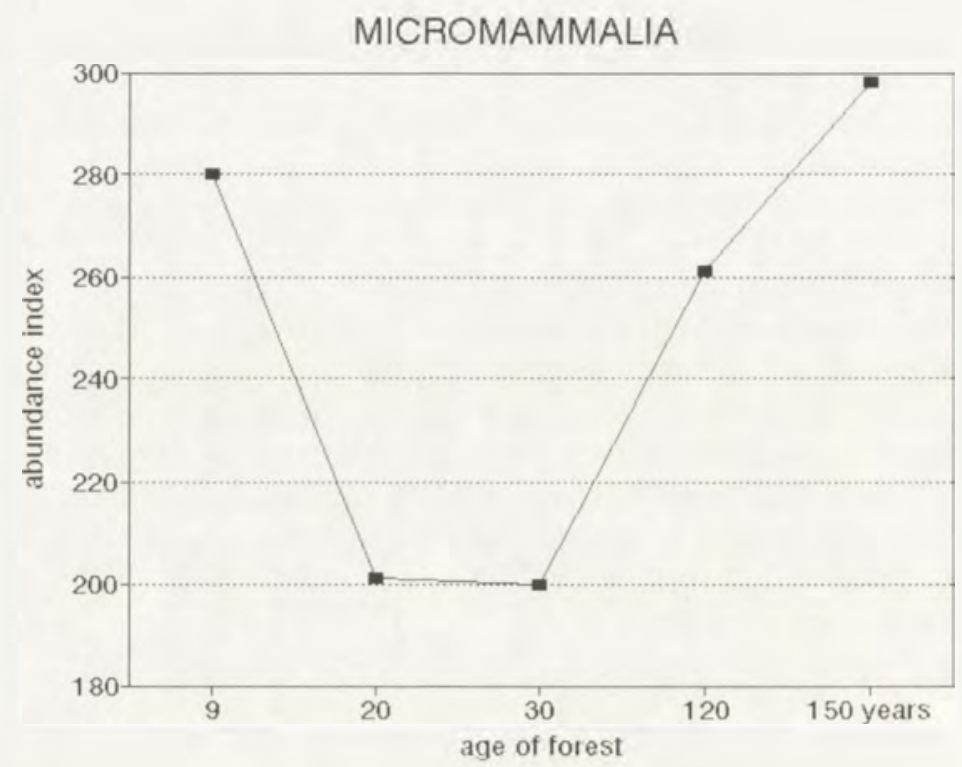

Fig. 56. Changes in the abundance of small mammals in relation to the age of pine forest stands

the rodents: bank vole (Clethrionomys glareolus) and field yellow-necked mouse (Apodemus flavicollis) and the insectivore shrews: Sorex araneus and Sorex minutus. It is interesting to note that the bank vole increases its share in the course of the sere, accounting for as many as $67 \%$ of the total number of small mammals caught, while the peak abundance of yellow-necked field mouse is registered in the pole wood. Reverse trends are observed in the zoohagous group. $\mathrm{S}$. araneus is most abundant in pine cultures, his abundance decreasing with the growing age of the stand. S. minutus exhibits larger variations in abundance that are not associated with the age of the forest stand. There is a considerable age-related decrease in the share of meadow and field species. Common vole (Microtus arvalis), quite common in the culture stage, disappears in the pole wood not to emerge again in mature forests. Short-tailed vole (Microtus agrestis) has a share of several percent in communities in each age class, but it was not registered in the pole wood. Harvest mouse (Micromys minutus) and northern birch mouse (Sicista betulina) are characterised by similar shares. Other species occur in the pine forest only sporadically.

Species diversity of small mammals is highest in cultures and young stands of pine (Fig. 58) decreasing in older stands to reach a minimum in the final link of the secondary sere. In this case also, the increase of community organisation is accompanied by the elimination of accessory species and the strengthening of the dominant position of species forming the core of the community. This is obviously reflected in the value of Pielou's index $(\mathrm{J})$, reflecting the degree of 


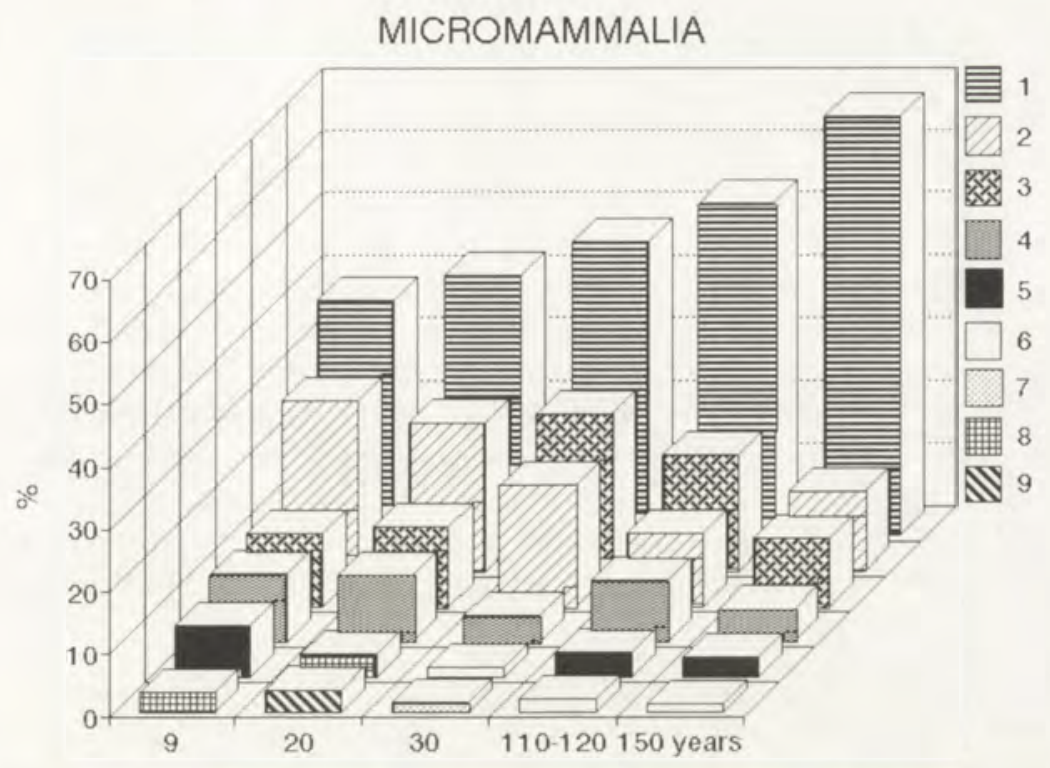

Fig. 57. Dominance structure of communities of small mammals in forest stands of various ages in Puszcza Białowieska: 1 - Clethrionomys glareolus, 2 - Sorex araneus, 3 - Apodemus flavicollis, 4 Sorex minutus, 5 - Microtus agrestis, 6 - Sicista betulina, 7 - Apodemus agrarius, 8 - Micromys minutus, 9 - Microtus arvalis

\section{MICROMAMMALIA}

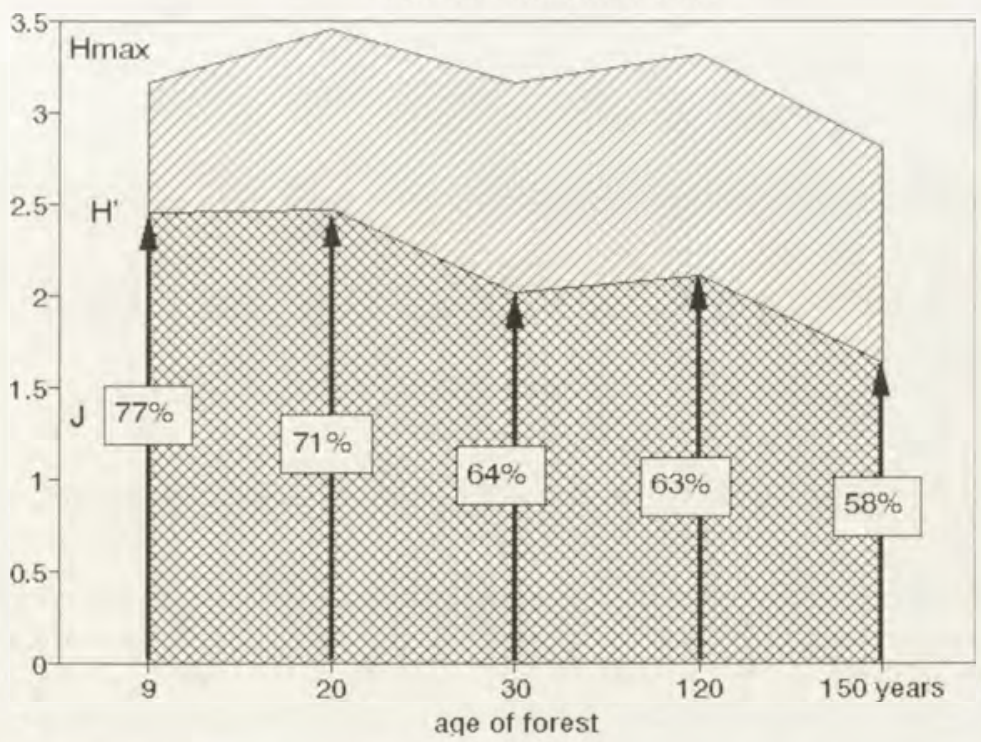

Fig. 58. Changes in actual $\left(\mathrm{H}^{ }\right)$and potential $\left(\mathrm{H}_{\max }\right)$ species diversity in communities of small mammals and the degree of realisation $(J)$ of potential diversity of the communities in the sere of the pine forest 
realisation of the potential for species diversity. The value of this index falls steadily throughout the sere.

Birds (Aves)

Nesting birds are represented in the pine forests of Puszcza Białowieska by 23 species. None of them occurs at every stage of the secondary succession (WOŁK, GUTOWSKI 1984). During the first years after a plantation of pine is started, the afforested clearings are settled by three field species. Their number increases up to eight species in a 9-17-year-old stand (Fig. 59), up to 11 after 22 years, to reach 16 in the oldest stands. In the latter stage, only typically forest species occur. This set of species, however, is only characteristic of larger and older pine forest complexes. In enclaves of mature forest surrounded by younger stands, the number of species of nesting birds falls by almost a $1 / 3$ i.e. down to 9. Distribution-based estimation of the number of species was only possible for 22-24-year-old stands. A value of $\mathrm{S}^{*}=11.07$ indicates that empirical data correspond to theoretical estimates.

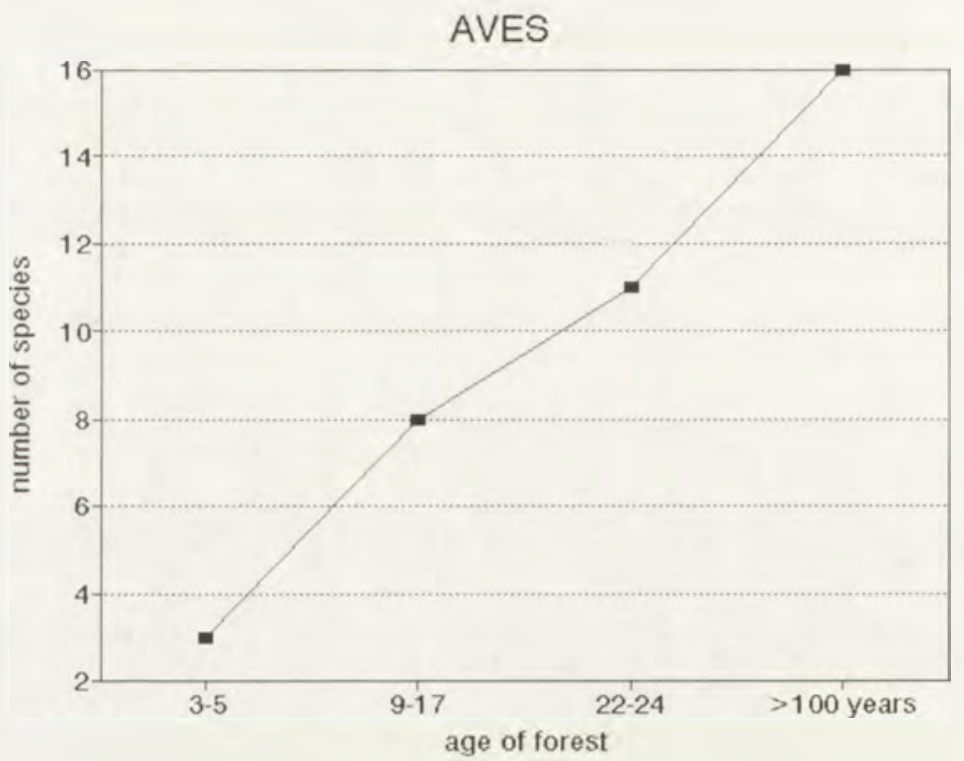

Fig. 59. Changes in the number of species of birds in relation to the age of pine forest stands

The number of couples of nesting birds per one hectare of forest is lowest in the culture stage and grows throughout the sere (Fig. 60). In cultures several years old the figure is 13 , compared to 33 couples/ha in large mature complexes. In small enclaves of mature forest characterised by poorer species composition, the nest density is even higher ( 39 couples/ha). This effect is mostly due to the high proportion of chaffinch (Fringilla coelebs) and goldcrest (Regulus regulus) which nest in mature enclaves. 


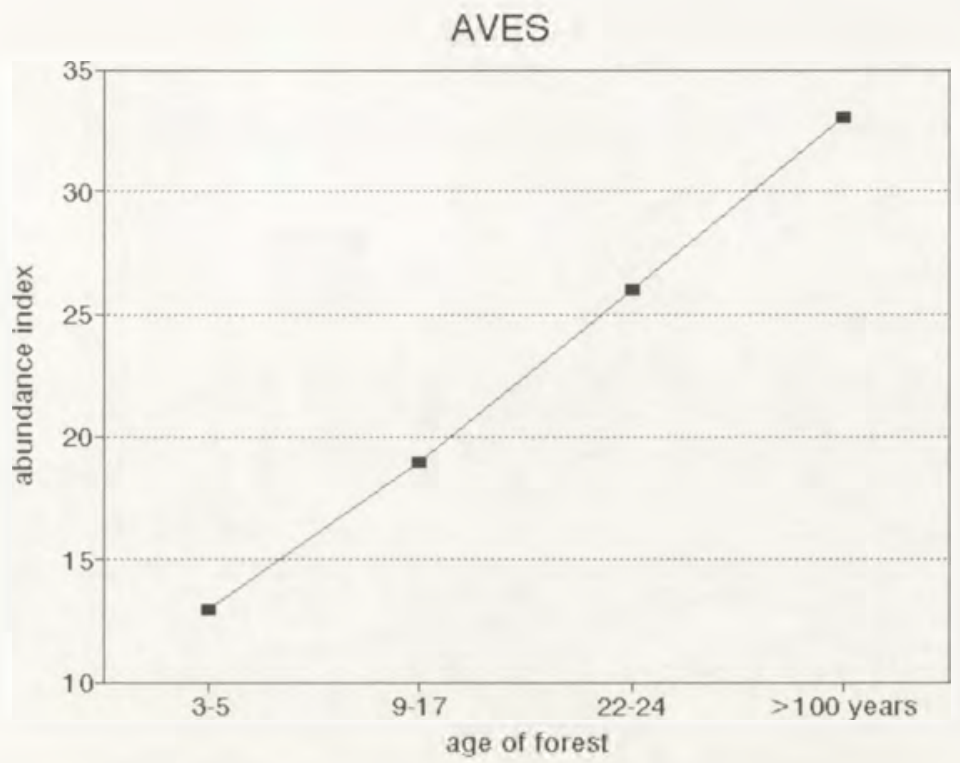

Fig. 60. Changes in the abundance of birds in relation to the age of pine forest stands

The structure of the community of birds is a dominant-type one (Fig. 61). Tree pipit (Anthus trivialis) is dominant in 3-5-year-old plantations, followed by wood lark (Lullula arborea), and yellowhammer (Emberiza citrinella) has the lowest share. The latter is dominant in 9-17-year-old stands, where tree pipit moves to the second position. The third position is occupied by hedge sparrow (Prunella modularis), a new species. In stands older than 20 years, the top position is occupied by robin (Erithacus rubecula), followed by two species: chiffchaf (Phylloscopus collybita) and wood warbler ( $P$. sibilatrix)). Hedge sparrow retains its high proportion. Similarly high is the share of a new species blackbird (Turdus merula). In stands older than 100 years the structure of the avian community is much more uniform, with chaffinch, goldcrest and wood warbler functioning as dominants. Crested tit (Parus cristatus) also has a significant share. Since older stands contain trees with hollows in the stems, a group of hollow-dwelling birds also appears.

Actual species diversity $\left(\mathrm{H}^{\prime}\right)$ of the avian community of pine forest increases throughout the secondary sere from 1.42 to 3.43 in the oldest stands (Fig. 62). A similar trend is noted in potential species diversity $\left(\mathrm{H}_{\max }\right)$, which equals 1.58 in the culture stage and 4.00 in older stands. The trend is present throughout the sere. The degree of approximation of the potential diversity, measured with Pielou's index, is very high in younger $(<25$ years $)$ stands $(\mathrm{J}=90.0 \%)$. It falls in older stands to $85.8 \%$, suggesting that in the case of birds, too, the process of formation of communities in mature ecosystems is accompanied by the increase of the degree of dominancy. 


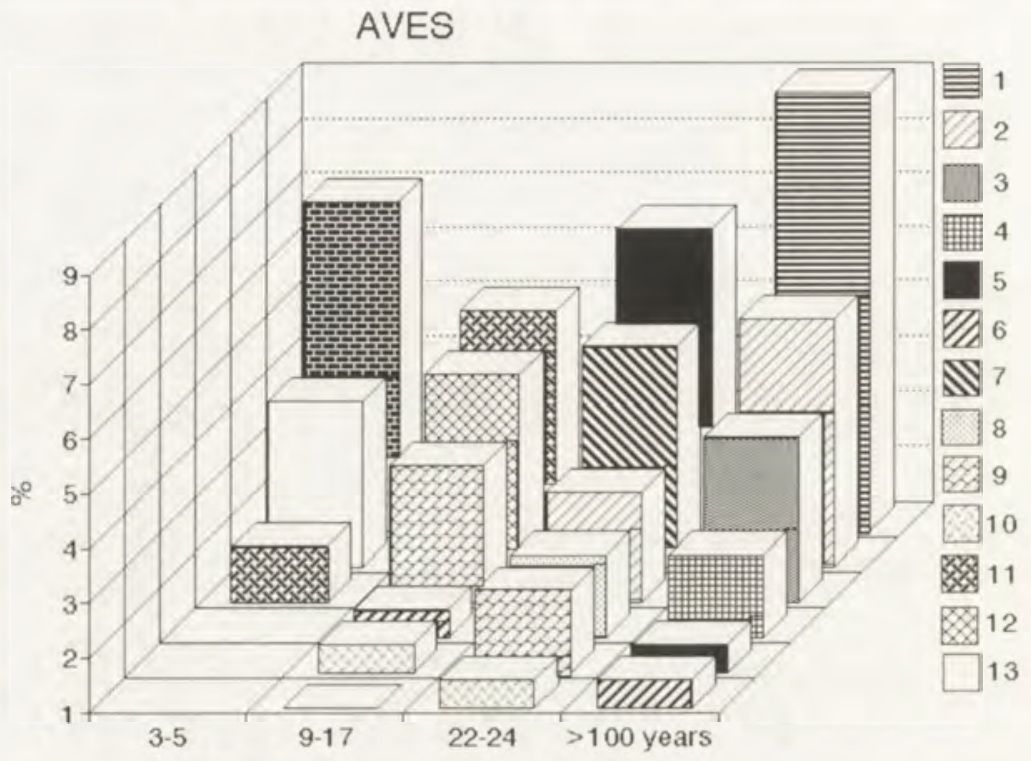

Fig. 61. Dominance structure of communities of nesting birds (Aves) in forest stands of various ages in Puszcza Białowieska; 1 - Fringilla coelebs, 2 - Phylloscopus sibilatrix, 3 -Regulus regulus, 4 Parus cristatus, 5 - Erithacus rubecula, 6 - Turdus philomelos, 7 -Phylloscopus colybita, 8 - Turdus merula, 9 - Prunella modularis, 10 - Phylloscopus trochilus, 11 - Emberiza citrinella, 12 - Anthus trivialis, 13 - Lullula arborea

\section{AVES}

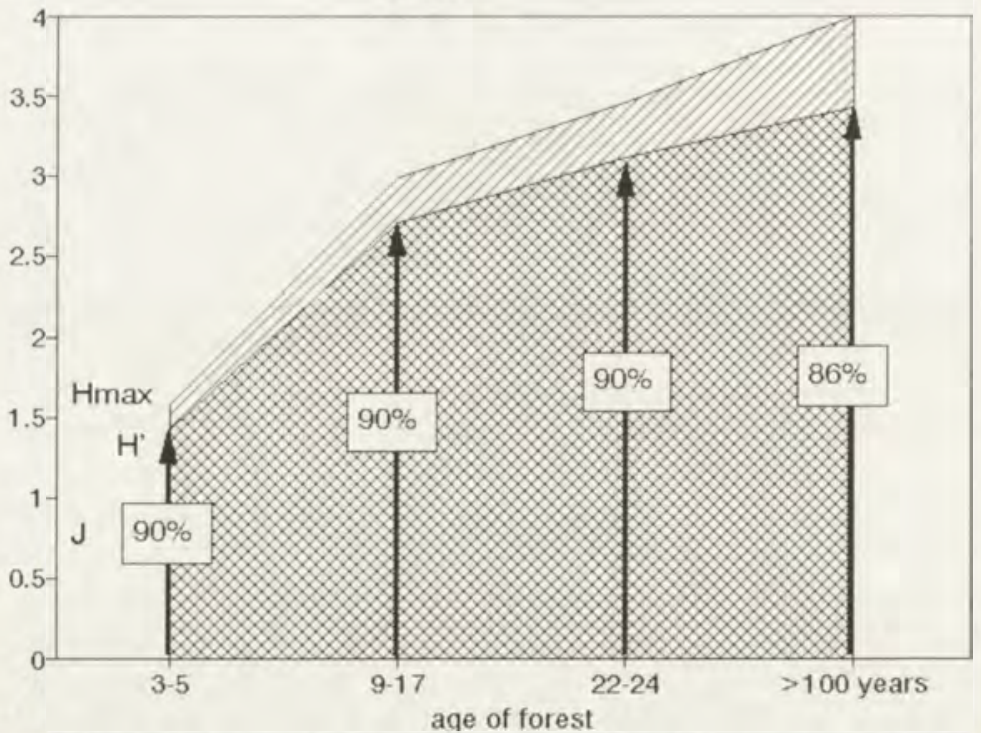

Fig. 62. Changes in actual $\left(\mathrm{H}^{\prime}\right)$ and potential $\left(\mathrm{H}_{\max }\right)$ species diversity in communities of birds and the degree of realisation $(\mathrm{J})$ of potential diversity of the communities in the sere of the pine forest 


\section{SUMMARY}

Because of the economic value of pine timber, Polish pine forests have been exploited and cultivated for hundreds of years. Most of the forests consist of even-aged stands, which are usually formed as a result of artificial restoration of complete cut down of trees. Starting a pine plantation in a clearing, usually with an addition of companion or shelter trees, initiates the process of secondary succession. In the course of secondary succession, the forest goes through several stages: culture, young growth, thicket, pole wood and maturing stand until it reaches the mature stage. In Polish pine forests, the process takes 120-150 years (SZUJECKI 1980).

Each of these stages is characterized by slightly different forest microclimatic conditions, which depend on the composition of the stand and habitat properties (OBMINSKI 1978). The changes influence the reconstruction of the plant cover. Secondary succession processes in the pine forests of Puszcza Białowieska are remarkably creative in this respect as they lead to the formation of the spatial structure typical of the coniferous forest with conspicuous vertical alignment and to filling the living space of the forest interior with species adapted to the habitat conditions which have developed in the course of secondary succession. It is a repetitive process that has been observed and described in coniferous forest habitats in various parts of the country.

As regards fauna, these processes have been only partially understood and data on the secondary succession of fauna pertain only to individual groups of animals so that it is impossible to fully portray the changes in composition and organisation of faunal complexes. On the background of the bibliography concerned with ecological succession, which is quite abundant, but often poorly related to "the real thing", the authors of this paper have addressed several questions that take into account the character of faunistical data. ensuring that a well-documented answer can be obtained.

The problem which appears central to our understanding of the topic is the character of the secondary succession of fauna - what and in what way does this process lead to. It is by no means obvious, unlike the case of forest plant cover, that in the process of secondary succession of fauna the biomass increases considerably and spatial structures are formed. Even if these phenomena actually take place, they still need to be evidenced for. The most important question is whether the secondary succession of fauna is uni- or multidirectional. The question concerns the very model of the process - whether it is entirely creative, and whether its stages consist in populating the ecological vacuum, forming ecosystems and adapting them to the ecological structure of the maturing forest. This clear picture raises a number of doubts. Is there an actual ecological vacuum during some time after clear-cutting, or is the open area immediately occupied? Do the various subsystems of the zoocenosis have to come into being or do they already exist in nature? And, finally, what does the adaptation consist in? More exactly, what do the various faunal groups actually adapt to? 
In order to obtain an unequivocal answer to the above questions, two working hypotheses were put forward, which were then verified with the materials collected and analysed.

The first hypothesis states that the secondary succession of fauna can develop in various ways and sometimes lead to dissimilar final systems. Five types of succession have been described: creative, stabilising, rise-and-fall, regressive and restorative (Fig. 3 ).

The second hypothesis interprets the interdependencies within the fauna as a hierarchical system of trophic relations. The core of the structure of the fauna is accordingly formed of systems related to one another by means of feeding relations, such as subsystem, food chain, competitive guild and population of a given animal species. These interrelations have been presented on the basis of 30 faunal groups included in the study of the final stage of secondary succession - the fauna of a mature pine forest.

So formulated, the working hypotheses have made it possible to compare faunal data with the ideas about the course of secondary succession. The following documentation materials for each of the age classes provided a basis for verifying the hypotheses:

1) the number of species forming the taxocenes or competitive guilds:

2) the abundance of these units, usually expressed in the form of indices in order to illustrate trends in abundance changes;

3) the structure of the taxocenes for illustrating changes in the organisation of zoocenotic systems;

4) actual and potential species diversity and their ratio measured with Pielou's index.

The number of species (Tab. II) exhibits six types of changes in the course of the secondary succession of pine forests in Puszcza Białowieska. The dominant trend is restorative succession where a high number of species occurs in the pine stand in the culture stage, decreasing in the pole wood stage to rise again in the mature forest. This trend was observed in half of the competitive guilds and 8 taxocenes studied. The second position is occupied by two other modes of secondary succession. Regressive succession, in the course of which the number of species constantly decreases, is found in 4 competitive groups and 5 taxocenes. Similarly, the rise-and-fall succession, where an initial increase in the number of species is followed by a fall, was observed in 5 competitive groups. Creative succession, characterized by a constant growth in the succession series, was only found in 4 competitive groups. Stabilisation of the number of species following an initial increase occurred only in 2 groups of animals. Apart from these 5 types of changes in the number of species, absence of such changes in the course of forest development was observed in the following 5 instances: the leaf beetles (Chrysomelidae), lady-birds (Coccinellidae), parasitic Pipunculidae, nematodes (Nematoda) and Rhagionidae (Diptera).

A similar diversification of responses of individual animal groups to the regeneration of a pine forest can be seen when analysing the competitive guilds separately (Tab. II). Where a group is composed of a number of taxons, the usual finding is that each of the taxons follows a different pattern of changes in the 
number of species. Zoophages as well as xylo- and cambiophages are exceptional in this respect, representing mostly the restorative type of changes in the number of species, while the decreasing trends prevail in the case of chewing phytophages.

Table II. Changes in the number of species of animal communities in the course of the secondary succession of the pine forests in Puszcza Bialowieska

\begin{tabular}{|c|c|c|c|c|c|c|c|}
\hline \multirow[b]{2}{*}{ Subsystem } & \multirow[b]{2}{*}{ Competitive guild } & \multicolumn{6}{|c|}{ Succession type } \\
\hline & & 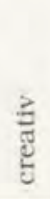 & 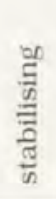 & 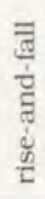 & 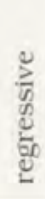 & 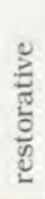 & 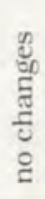 \\
\hline \multirow{6}{*}{ Biotrophes } & sucking phytophages & 1 & - & 1 & - & 1 & - \\
\hline & chewing phytophages & 1 & - & - & 2 & - & 1 \\
\hline & xylo- and cambiophages & - & 1 & - & - & 2 & - \\
\hline & zoophages & - & - & 1 & - & 3 & - \\
\hline & aphidophages & 1 & - & 1 & 1 & - & 1 \\
\hline & parasitoids & - & - & 1 & - & 1 & 1 \\
\hline \multirow{2}{*}{ Saprotrophes } & saprophages & - & 1 & 1 & - & - & 1 \\
\hline & soil pantophages and predators & - & - & - & 1 & 1 & 1 \\
\hline \multirow{2}{*}{ Macrotrophes } & birds & 1 & - & - & - & - & - \\
\hline & mammals & - & - & - & 1 & - & - \\
\hline & Total & 4 & 2 & 5 & 5 & 8 & 5 \\
\hline
\end{tabular}

The results of the analysis of changes in the basic components of forest ecosystem organisation, as one can call animal species, indicate that the constructive processes of expansion or regeneration of systems, represented by creative, stabilising and restorative succession, are as marked as the destructive processes reflected in the final outcome as a fall in the number of species. At the same time it is symptomatic that one out of every six groups of animals does not respond to the processes operating in the developing forest by changing the number of species.

The changes in the abundance of animal communities (Tab. III) are as diverse as the trends in the number of species. However, two patterns prevail: regression and restoration. About $1 / 3$ of the animal communities are more abundant at the beginning of succession than in mature stands, so that the decreasing trend predominates. The second most frequent type of succession is seen in those communities wherein in the course of succession the decrease is arrested and abundance increases in older stands. A steady increase in abundance 
throughout the succession series is reported only in one out of every 7 taxocenes. Also in every seventh group no abundance changes are recorded resulting in a constant density throughout the series. A decrease following an initial rise is observed in every fifteenth taxocene, while in one case only, namely in springtails (Collembola), the changes in abundance indicate stabilisation in older stands.

Table III. Types of changes in species abundance in animal communities in the course of the secondary succession of the pine forests in Puszcza Białowieska

\begin{tabular}{|c|c|c|c|c|c|c|c|}
\hline \multirow[b]{2}{*}{ Subsystem } & \multirow[b]{2}{*}{ Competitive guild } & \multicolumn{6}{|c|}{ Succession type } \\
\hline & & ¿ & 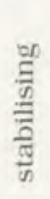 & 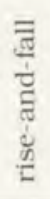 & 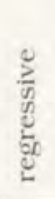 & 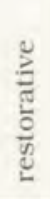 & 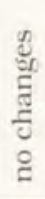 \\
\hline \multirow{6}{*}{ Biotrophes } & sucking phytophages & 1 & - & - & 2 & - & - \\
\hline & chewing phytophages & - & - & 1 & - & - & 2 \\
\hline & xylo- and cambiophages & - & - & - & 1 & 2 & - \\
\hline & zoophages & - & - & - & 3 & 1 & - \\
\hline & aphidophages & 2 & - & - & 1 & 1 & - \\
\hline & parasitoids & - & - & - & 1 & 1 & - \\
\hline \multirow{2}{*}{ Saprotrophes } & saprophages & - & 1 & - & - & 1 & 1 \\
\hline & soil pantophages and predators & - & - & 1 & 1 & 1 & - \\
\hline \multirow{2}{*}{ Macrotrophes } & birds & 1 & - & - & - & - & - \\
\hline & mammals & - & - & - & - & 1 & 1 \\
\hline & Total & 4 & 1 & 2. & 9 & 8 & 4 \\
\hline
\end{tabular}

When the phenomena are analysed from the viewpoint of individual competitive groups, it can be seen that the responses to succession within each group are visibly diversified. In each group of invertebrates one can find taxocenes whose abundance increases steadily, and others, whose abundance falls. Non-specialised zoophages are an exception in this respect since the prevailing tendency in that group is a decrease in abundance.

Analysis of changes in abundance of the fauna provides an answer to two important questions related to secondary succession of pine forests. The notion of a "faunal vacuum" is not compatible with the facts. The forest clearing is immediately occupied by animal populations of high abundance; almost $2 / 3$ of animal communities decrease their abundance in the course of succession.

Increasing abundance can be observed only in $1 / 4$ of the animal groups (Tab. III): sucking phytophages, aphidophages and birds. 
Abundance is a measure of the ecological success of both the species and the animal community. In the course of secondary succession of a pine forest, changes are seen in the manner of utilisation of the mass produced by the green plants. As the forest develops, phytophages with a biting mouth apparatus which eat conifers of pine are replaced by the less dangerous sucking phytophages which suck out the products of assimilation. The phenomenon can be seen at least in Puszcza Bialowieska, where the pine forests are not subject to disastrous invasions of the chewing phytophages. An increase in the abundance of the sucking phytophages is accompanied by the development of groups of aphidophages which regulate the abundance of the former. Very important is the increase in abundance of the competitive group of birds, mostly insectivores. which act as an element controlling other elements, particularly the subsystem of biotrophes.

Changes in actual species diversity (Tab. IV), measured with Shannon-Weaver's index $\left(\mathrm{H}^{\prime}\right)$, are most uniformly distributed among the various models of succession. The most frequent processes are reduction of diversity in comparison with the initial situation, but, all in all, the increasing trend in the diversity of animal communities is encountered as frequently as the reverse process. Another frequently observed phenomenon is a fall in diversity after a period of rise. The picture changes a little when one considers it from the viewpoint of realising the potential for species diversity in the ecosystem. Here, the prevailing process is reduction of diversity, especially in mature stands. Reduction was observed in 17 communities out of 28 investigated in this respect. Increase, restoration or stabilisation of diversity after an increase were registered in only $1 / 3$ of the cases. Absence of changes of diversity throughout the succession series is very rare.

The results of the above analysis indicate clearly that MacArthur's (1958) thesis "diversity makes stability" is not confirmed by empirical data. On the contrary, the decrease in species diversity observed in the mature stands of the pine forest implies that the increase in the degree of organisation of a system takes place at the expense of decreasing its internal diversification. This is related to community structure. In mature stands, there is usually one or a few dominant species in a community and the "tail" of accessory species becomes notably shorter. The organisation of a community is usually built on a few well-adapted species forming competitive groups.

In conclusion it should be stressed that the most outstanding feature of secondary succession of the fauna in the pine forests in Puszcza Białowieska is the multidirectional character of processes taking place in a growing pine forest which is developing its spatial structure. If one considers the parameters studied: the number of species, abundance, species diversity and structure, it is easy to notice that the decreasing trends in the parameters studied predominate - either throughout the succession series or in its final stage $44 \%$ of cases). Stabilisation of these parameters throughout the series or after a period of growth can only be seen in $22 \%$ of cases. An increase, either steady or following a period of reduction, is only observed in $34 \%$ of the cases. 
Table IV. Types of changes in actual species diversity $\left(\mathrm{H}^{\prime}\right)$ in animal communities in the course of the secondary succession of the pine forests in Puszcza Białowieska

\begin{tabular}{|c|c|c|c|c|c|c|c|}
\hline \multirow[b]{2}{*}{ Subsystem } & \multirow[b]{2}{*}{ Competitive guild } & \multicolumn{6}{|c|}{ Succession type } \\
\hline & & $\underset{\mathbb{J}}{\stackrel{Z}{J}}$ & 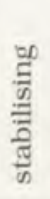 & 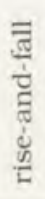 & 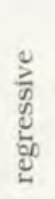 & 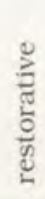 & $\begin{array}{l}y \\
\text { of } \\
\text { 절 } \\
\text { है } \\
\text { ㅇ }\end{array}$ \\
\hline \multirow{6}{*}{ Biotrophes } & sucking phytophages & 1 & - & - & 2 & - & - \\
\hline & chewing phytophages & - & - & 1 & - & - & 2 \\
\hline & xylo- and cambiophages & 1 & 1 & - & - & 1 & - \\
\hline & zoophages & 1 & 1 & 1 & - & 2 & - \\
\hline & aphidophages & 1 & - & 1 & 2 & - & - \\
\hline & parasitoids & - & 1 & 1 & 1 & - & - \\
\hline \multirow{2}{*}{ Saprotrophes } & saprophages & - & 1 & 1 & - & - & 1 \\
\hline & soil pantophages and predators & - & 1 & - & 1 & - & - \\
\hline \multirow{2}{*}{ Macrotrophes } & birds & 1 & - & - & - & - & - \\
\hline & mammals & - & - & - & 1 & - & - \\
\hline & Total & 5 & 5 & 5 & 7 & 3 & 3 \\
\hline
\end{tabular}

These data confirm the hypothesis of multidirectional character of the processes of secondary succession in animal communities. Particularly important is the decrease in the value of many indices characterizing the fauna in the final stage of succession, which can be termed the stage of community organisation. It takes place at the cost of reducing the number of species and diversity for the sake of stabilisation of dominance structures. Ecosystem stability is thus ensured by the better adapted forms while the diversity potential is not fully utilised.

All elements of the zoocenotic system are formed simultaneously in the early stage of planting the stand after clear-cutting. At this stage the system is the richest. In the subsequent stages its organisation is only restructured in accordance with the development of the forest as an ecosystem.

\section{BIBLIOGRAPHY}

ANDERSON D. J. 1986. Ecological succession. In: Community ecology eds. J. KIKKAwAa, D. J. ANDERSON. Pattern and Process., Blackwell Sc. Publ., Melbourne: 269-285.

Bańкоwska R. 1982. Bzygowate (Syrphidae, Diptera). W: Zoocenologiczne podstawy ksztaltowania środowiska przyrodniczego osiedla mieszkaniowego Białolęka Dworska w Warszawie. Fragm. faun., Warszawa, 26: 407-420. 
BANKowSkA R. Diversification of Syrphidae (Diptera) fauna in the canopy of Polish pine forests in relation to forest stand age and best health zone. Fragm. faun.. Warszawa, (w druku).

Brzzeskı M., Szczygieł A.; Glạba B. 1976. Zbiốr metod laboratoryjnych stosowanych w nematologii. Kom. Ochr. Roślin PAN, Warszawa, 31 pp.

Choвorow J. 1993. Cantharidae (Coleoptera) of pine forests in Poland. Fragm. faun, Warszawa, 36 : 147-156.

CMoluchowa A. Lechowski L. 1993. Heteroptera communities of pine forests in Poland. Fragm. faun., Warszawa, 36: 127-147.

Coller B. D., Cox G. W., Johnson A. W.. Miller P. C. 1978. Ekologia dynamiczna. PWRil, Warszawa, $544 \mathrm{pp}$.

COWLES H. C, 1899. The ecological relations of the vegetation on the sand dunes of Lake Michigan. Bot. Gaz.. 27: 95-391.

Czechowska W. 1981. Biedronkowate (Coccinellidae, Coleoptera). W: Zoocenologiczne podstawy ksztaltowania środowiska przyrodniczego osiedla mieszkaniowego Białolęka Dworska w Warszawie. Fragm. faun., Warszawa, 26: 249-267.

CZECHowska W. 1985. Neuropterans (Planipennia and Raphidioptera; Neuropteroidea) communities of coniferous forests in the Kampinoska Forest and Białoleka Dworska near Warsaw. Fragm. faun., Warszawa, 19: 391-404.

DZIABASZEWSKI A. 1976. Studium ekologiczno-faunistyczne nad pajęczakami (Aranea. Opiliones. Pseudoscorpionidae) koron drzew. Uniw. A. Mickiewicza w Poznaniu, seria zoologiczna, Poznan. 4: $215 \mathrm{pp}$.

FALINSKA K. 1991. Sukcesja jako efekt procesów demograficznych roślin. Phytocoenosis, WarszawaBiałowieźa, 3: 43-68.

FAL.INSKI J. B. 1988. Succession regeneration and fluctuation in the Biafowieza Forest (NE Poland). Vegetatio, 77: 115-128.

FALINSKı J. B. 1989. Syndynamiczna interpretacja krajobrazu. W: Wplyw gospodarki leśnej na srodowisko. SGGW-AR, Warszawa,:103-136.

FALıNSKI J. B. 1991. Procesy ekologiczne w zbiorowiskach leśnych. Phytocoenosis, Warszawa-Białowiez̀a, 3: 17-42.

GIl.ter P. S. 1984. Community structure and the Niche after Paoletti M. G., Foissner W., Coleman D. 1993. Soil biota, nutrient cycling, and farming systems. Lewis Publ.: 91-111.

Gray A. J., Crawley M. J., Edwardsds P. J. eds. 1987. Colonisation, succession and stabilites. Blackwell Sc. Publ.

HORGOTT H. 1960. Untersuchungen über die qualitative und quantitative zusammensetzung der Arthropodenfauna in den Kieferkronen. Beitr. Ent., Berlin, 10: 891-916.

KACZMAREK W. 1963. An analysis of interspecyfic competition in communities of the soil macrofauna of some habitats in the Kampinos National Park. Ekol. Pol. A., Warszawa, 11: 1-62.

KARPinski J. J. 1949. Materiały do bioekologii Puszezy Bialowieskiej. IBL, Rozprawy i sprawozdania seria A, Warszawa, 56:212 pp.

KARPINSKI J. J. 1956. Mrówki w biocenozie Białowieskiego Parku Narodowego. Roczn. Nauk. les̉n..Warszawa, 14: 201-221.

KARPINSKI J. J., Okołów Cz. 1969. Bibliografia Bialowieska (za okres do końca 1966). Min. Leśn. i P. D.. Zarząd Ochrony Przyrody, Warszawa, 208 pp.

KıкKawa J. 1986. Complexity. Diversity and Stability. In: Community Ecology eds. J. KıкKaWA. D. J. Anderson. Pattern and Process., Blackwell Sc. Publ., Melbourne: 41-62.

Klausnitzer B. 1968. Zur Biologie von Myrrha octodecimguttata (L.) (Col. Coccinellidae). Ent. Nachr., Dresden, 12: 102-104.

KLomp H., TEERINK B. J. 1973. The density of the invertebrata summer fauna on the crowns of pine trees, Pinus silvestris, in central part of the Netherlands. Beitr. Ent., Berlin, 23: 325-340.

KoEHLer H., BorN H. 1989. The influence of vegetation structure on the development of soil mesofauna. Agriculture, Ecosystems and Environment, 27: 253-269.

KolodzieJaK E. Communities of Lachnidae (Aphidoidea) inhabiting pine canopies in Polish pine forests sittuated in three forest health zones. Fragm. faun., Warszawa, (w druku).

Kornas J. 1950, Revue systematique et spectre de la biologie florale des associations vêgétales rocheuses du Jura Cracovien. Bull. Acad. Pol. Sci. Lettr., Cl. Math.-Nat., ser. B (1).

Lindemann R. L. 1942. The trophic-dynamic aspect of ecology. Ecology, 23: 399-418. 
LOHM U.. LUNUNDKVIST H. PERSSON T.. WIREN A. 1977. Effect of nitrogen fertilization on the abundance of enchytraeids and microarthropods in Scots pine forests. Studia Forestalia Suecica. 140, 23 pp.

LUCZAKJ. 1963. Differences in the structure of communities of web spiders in one type of environment (young pine forest). Ekol. Pol. A. 11: 160-221.

MACARTHUR R. 1955. Fluctuations in animal populations and a measure of community stability. Ecology. 36: 533-536.

MACMAHON J. 1980. Ecosystems over time: succession and other types of change. In: Forests. Fresh perspectives from ecosystem analyses ed. R. Waring. Oregon State Univ. Press: 27-58.

MARGalef R. 1968. Perspectives in Ecological Theory. Univ. Chicago Press, Chicago-London, $111 \mathrm{pp}$.

MAtuszkiewicz.. Degorski M., Koziowska A. 1993. Description of the plant association structure and soils of pine forest stands situated in five regions of Poland. In: Species composition and structure of pine forests fauna in Poland. Part I. Fragm. faun., Warszawa, 36: 13-36.

Mıкоцалсzук W. 1991. Rhagionidae (Diptera) Gör Swiẹtokrzyskich. Fragm. faun., Warszawa, 35 : 83-87.

MOERICKE V. 1950, Uber den Farbensinn der Pfirschblattlaus Myzodes persicae Sulz. Z. Tierpsychol., Berlin, Hamburg, 7: 265-274.

Oвмınsкı Z. 1978. Ekologia lasu. PWN, Warszawa, 481 pp.

O'CONNOR F. B. 1971. The enchytraeids. In: Methods of study in quantitative soil ecology: population, production and energy flow (ed. by J. Phillipson). London, Oxford, Edynburgh: 83-106.

ODum E. P. 1969. The strategy of ecosystem development. Science, 164: 262-270.

Odum E. P. 1971. Fundamentals of Ecology (3rd edn). W. B. Saunders, Philadelphia. 1.6.1.

Odum E. P. 1977. Podstawy ekologii. PWRiL, Warszawa, 678 pp.

Okolow Cz. 1976. Bibliografia Puszczy Bialowieskiej 1967-1972. Bialowieski Park Narodowy. Białowieża, 164 pp.

Окоцów Cz. 1983. Bibliografia Puszczy Białowieskiej 1973-1980. Białowieski Park Narodowy. Białowieża, $190 \mathrm{pp}$.

Okolow Cz. 1991. Bibliografia Puszczy Białowieskiej 1981-1985. Białowieski Park Narodowy. Białowieża, $143 \mathrm{pp}$.

Oıson J. S, 1958, Rates of succession and soil changes on Southern Lake Michigan sand dunes. Bot. Gaz., 119; 125-483.

PAczoskı J. 1951. Dzieła wybrane. PWRiL, Warszawa, 393 pp.

PAWLowskı B. 1959. Skład i budowa zbiorowisk roślinnych oraz metody ich badania. W; Szata roślinna Polski, PWN, Warszawa.

PETERSEN H., KRoGH P. H. 1987. Effects of perturbing microarthropods communities of a permanent pasture and rye field by an insecticide and a fungicide. In: Soil fauna and soil fertility ed. by B. R. Striganova. Proccedings of the 9th International Colloquium on Soil Zoology. Moskow 1985: 217-229.

PEtAL. J. 1977. The role of ants in ecosystems. In: Production ecology of ants and termites (ed. M. V. Brian). IBP 13, Cambridge Univ. Press: 293-325.

PIANKA J. F. 1966. Latitudinal gradients in species diversity; a review of concepts. Am. Nat, 100 (910): 33-46.

PILIPIUK I. 1993. Enchytraeidae (Oligochaeta) of pine forest in Poland. Fragm. faun., 36: 75-107.

PiSARSkı B. 1975. Mrówki-Formicoidea. Katalog Fauny Polski, Warszawa, 26. 1. 84 pp.

PISARSKI B., CZECHOWSKI W. 1994. Ways to reproductive succes of wood ant queens. Memorabilia Zool., Warszawa, 48: 181-186.

PONGE J-F. 1993. Biocenoses of Collembola in atlantic temperate grass-woodland ecosystems. Pedobiologia, 37: 223-244.

PRENTICE I. C. 1986. Some concepts and objectives of forest dynamics research. In: Forest dynamic research in Western and Central Europe ed. F. Hanta. Pudoc, Wageningen: 32-41.

SHELFORD V. E. 1913. Animal communities in temperate America. Univ. Press, Chicago-Illinois.

SHLYAKTENOK A. S. Distribution of spider and digger wasps (Hymenoptera, Pompilidae, Sphecidae) in a mossy pine forest (Pinetum pleurosum) in the Berezinsky Biosphere Reserve. Fragm. faun.. Warszawa, (w druku).

SHugart H. H. 1984. A theory of forest dynamics. Springer-Verlag. 
SKIBINSKA E. 1981. Żadłôwki (Aculeata, Hymenoptera). W: Zoocenologiczne podstawy kształtowania środowiska przyrodniczego osiedla mieszkaniowego Białołeka Dworska w Warszawie. Fragm. faun., Warszawa, 26: 355-378.

SøERENSEN T. 1948. A method of establishing groups of equal amplitude in plant sociology based on the similarity of species content and its application to analyses of the vegetation on Danish commons. Biol. Skr.. 5: 1-34.

STERZNŃSKa M. Ślepowroński A. Spiders (Aranei) of tree canopies in polish pine forests. Fragm. faun., Warszawa, (w druku).

Stugren B. 1976. Zasady ekologii ogólnej. PWN. Warszawa. 210 pp.

SZU.Jeckı A. 1980. Ekologia owadów leśnych. PWN. Warszawa, 603 pp.

Tol.KAC V. N.. Dackevic V. N. 1974. Estestvennoe vozobnovlenie v sosnovych tipach lesa. Belov. Puśča-Issl. 8: 29-48.

Trojan P. 1970. Muchówki - Diptera. Therevidae. Klucze do oznaczania owadów Polski. Warszawa. Cz. 28, 28 pp.

TROJAn P. 1975. Ekologia ogólna. PWN. Warszawa, 419 pp.

Trojan P. 1984. Ecosystem homeostasis. PWN, Warszawa; Dr W. Junk Publ., The Hague.

Trouan P. 1992. Analiza struktury fauny. Memorabilia Zool.. Warszawa, 47, 122 pp.

Whittaker R. H. 1975. Communities and ecosystems. McMillan Publ. Co.. New York, 385 pp.

WiEcko E. 1972. Puszcza Bialowieska. PWN, Warszawa, 193 pp.

Wolk K. Gutowski J. 1984. Relation between distribution of fauna and forest stand age in a fresh coniferous forest habitat in the Bialowieza Forest. In: II Symp. on the Protection of Forest Ecosystems. Rogów. 7-8 XII 1981: 139-153.

\section{Manuscripto}

BRzESKı M. 1994. Nicienie gleby i mchu boru świeżego w rozmaitych klasach wieku.

CiUUdzickA E. 1994. Zmiany zgrupowań piewików (Homoptera, Auchenorrhyncha) w szeregach sukcesyjnych borów świeżych (Peucedano-Pinetum) Puszczy Bialowieskiej.

Czechowska W. 1994. Sukcesja biedronkowatych (Coccinellidae, Coleoptera) w borach świezych Puszczy Białowieskiej.

Czechowska W. 1994. Sukcesja siatkoskrzydłych (Neuropteroidea) w borach świeżych Puszczy Bialowieskiej.

Сzechowsıı W. 1994. Sukcesja mrówek (Hymenoptera, Formicidae) w borach swieżych Puszczy Bialowieskiej.

GuTowsкı J. M. 1994. Zmiany zgrupowań kózkowatych i bogatkowatych (Coleoptera: Cerambycidae, Buprestidae) towarzyszace sukcesji wtórnej lasu w borach świeżych Puszczy Białowieskiej.

Pıupıuk I. 1994. Zgrupowania Enchytraeidae w szeregu sukcesyjnym borów świeżych Puszczy Bialowieskiej.

PUсEк M. 1990. Drobne ssaki borów świeżych Puszczy Białowieskiej.

SkiBıńSKA E. 1994. Zmiany zgrupowań grzebaczowatych (Sphecidae, Aculeata) w szeregu sukcesyjnym borów świeżych (Peucedano-Pinetum) Puszczy Bialowieskiej.

StERzYNSKA M. 1994. Pajaki (Aranei) koron sosen w borach świeźych Puszczy Białowieskiej.

STERzYNSKA M. 1994. Zgrupowania Collembola w szeregu sukcesyjnym borów swieżych Puszczy Bialowieskiej.

Trojan P. 1992. Raport o stanie zbadania fauny Puszczy Bialowieskiej.

WASOWSKA M. 1994. Struktura stonkowatych (Chrysomelidae, Coleoptera) w borach świeżych Puszczy Bialowieskiej.

Wisniewska K. 1994. Analiza rozwoju ryjkowców (Coleoptera, Curculionidae) w szeregu sukcesji wtórnej borów sosnowych Puszczy Białowieskiej. 


\section{AN INVENTORY OF SPECIES OCCURRING IN THE PINE FORESTS \\ OF PUSZCZA BIALOWIESKA}

\section{LACHNIDAE (APHIDOIDEA, HOMOPTERA)}

1 Cinara pinea (MORDR.)

2 Cínara pilosa (ZeTr.)

3 Cinara pini (L.)

4 Cinara pinihalbitans (MORDR.)

5 Schizolachnus pineti (F.)

6 Eulachnus agilis (KALT.)

\section{AUCHENORRHYNCHA (HOMOPTERA)}

Delphacidae

1 Criomorphus albomarginatus CURT.

2 Javesella pellucida (F.)

3 Paradelphacodes paludosus (Fr.) Cicadidae

4 Cicadetta montana (SCOP.) Cercopidae

5 Aphrophora corticea (Germ.) Membracidae

6 Centrotus cornutus (L.) Cicadellidae

7 Oncopsis flavicollis (L.)

8 Empoasca vitis (GoETHE)

9 Eupteryx atropunctata (GOEZE)

10 Eurhadina pulchella (FALL.)

11 Wagneripteryx germari (ZETT.)

12 Arboridia parvula (Вон.)

13 Zygina flammigera (FoURCR.)

14 Allygus mixtus (F.)

15 Colobotettix morbillosus (MEL.)

16 Grypotes puncticollis (H.-S.)

17 Hesium domino (REuT.)

18 Jassargus flori (FIEB.)

19 Macrosteles laevis (RIB.)

20 Psammotettix alienus (DHLB.)

21 Speudotettix subfusculus (FALL.)

\section{HETEROPTERA}

1 Sehirus luctuosus Muts. et R.

2 Adomerus biguttatus (L.)

3 Tritomegas bicolor (L.)

4 Aelia acuminata (L.)

5 Aelia klugi HAHN

6 Eysarcoris aeneus (Scop.)
7 Stagonomus pusillus (H.-S.)

8 Holcostethus vernalis (WoLfF.)

9 Palomena prasina (L.)

10 Palomena viridissima (PODA)

11 Pitedia juniperina (L.)

12 Pitedia pinicola (Muls. et R.)

13 Carpocoris purpureipennis (DE GEER)

14 Carpocoris fuscispinus (Вон.)

15 Carpocoris pudicus (PODA)

16 Dolycoris baccarum (L.)

17 Eurydema oleraceum (L.)

18 Piezodorus lituratus (F.)

19 Picromerus bidens (L.)

20 Troilus luridus (F.)

21 Rhacognathus punctatus (L.)

22 Acanthosoma haemorrhoidale (L.)

23 Elastotethus interstinctus (L.)

24 Elasmucha ferrugata (F.)

25 Elasmucha fieberi (JАK.)

26 Elasmucha grisea (L.)

27 Coreus marginatus (L.)

28 Corizus hyoscyami (L.)

29 Rhopalus parumpunctatus (SCHEL.)

30 Rhopalus maculatus (FIEB.)

31 Myrmus miriformis (FAL.L.)

32 Stictopleurus pictus (FIEB.)

33 Dicranocephalus agalis (Scop.)

34 Nithecus jacobeae (ScHiLl.)

35 Nysius thymi (WolfF)

36 Nysius ericae (ScHil.)

37 Nysius helveticus (H.-S.)

38 Kleidocerys resedae (PAnz.)

39 Cymus obliguus (HoRv.)

40 Cymus claviculus (FALL.)

41 Cymus melanocephalus (FIEB.)

42 Geocoris grylloides (L.)

43 Geocoris ater (F.)

44 Stygnocoris pygmaeus (F. SAHLB.)

45 Stygnocoris pedestris (FALL.)

46 Megalonotus chiragra (F.)

47 Megalonotus sabulicola (Tномs.)

48 Pterotmetus staphyliformis (SCHIL.).

49 Rhyparochromus pini (L.) 
50 Ischnocoris angustulus (ВоH.)

51 Drymus ryei Dougl. et Sc.

52 Drymus brunneus (F. SAHLB.)

53 Eremocoris plebejus (FALL.)

54 Eremmocoris abietis (L.)

55 Scolopostethus decoratus (HAHN)

56 Pachybrachius fracticollis (ScHIL.)

57 Neides tipularius L.

58 Saldula vestita (Dougl.)

59 Acalypta carinata (PANZ.)

60 Acalypta nigrina (FAlL.)

61 Acalypta marginata (WoL.FF)

62 Acalypta gracilis (FIEB.)

63 Himacerus apterus (F.)

64 Nabicula limbata (DAHLB.)

65 Nabis ferus (L.)

66 Nabis pseudoferus REM.

67 Nabis punctatus A. CostA

68 Nabis ericetorum SCHOL.TZ

69 Nabis rugosus (L.)

70 Myrmedobia exilis (FALL.)

71 Myrmedobia distinguenda ReuT.

72 Anthocoris nemorum (L.)

73 Anthocoris confusus REur.

74 Acompocoris pygmaeus (FALL.)

75 Orius niger WoLFF

76 Orius minutus (L.)

77 Orius agilis (FLOR)

78 Monalocoris filicis (L.)

79 Bothynotus pilosus (Вон.)

80 Deraeocoris ruber (L.)

81 Alloeotomus gothicus (FALL.)

82 Myrmecoris gracilis (J. SAHLB.)

83 Leptopterna ferrugata (FALL.)

84 Leptopterna dolobrata (L.)

85 Stenoderma calcaratum (FALL.)

86 Stenoderma virens (L.)

87 Stenoderma laevigatum (L.)

88 Stenoderma holsatum (F.)

89 Notosistra erratica (L.)

90 Trigonotylus coelestialium (КIRk.)

91 Trigonotylus ruficornis (GEOFFR.)

92 Phytocoris longipennis FLOR

93 Phytocoris pini Kırschв.

94 Adelphocoris reicheli (FIEB.)

95 Caloris biclavatus (H.-S.)

96 Caloris affunis (H.-S.)

97 Caloris norvegicus (GMEL.)
98 Stenotus binotatus (F.)

99 Lygocoris pabulinus (L.)

100 Lygus rugulipennis (Popp,)

101 Lygus pratensis (L.)

102 Lygus punctatus (ZETT.)

103 Camptozygum aequale (ViL.)

104 Charagochilus gyllenhali (FAL..)

105 Capsus pilifer REM.

106 Capsodes gothicus (L.)

107 Halticus pusillus (H.-S.)

108 Heterotoma meriopterum (Scop.)

109 Heterocordylus genistae (Scop.)

110 Orthotylus ericetorum (FALL.)

111 Globiceps flavomaculatus (F.)

112 Globiceps cruciatus Reur.

113 Blepharidopterus brevicoornis (WAGN.)

114 Phoenicocoris modestus (MEY,-D.)

115 Phoenicocoris obscurellus (FALL.)

116 Atractotomus mali (MEY,-D.)

117 Psallus varians (H.-S.)

118 Plesiodema pinetellum (ZETT.)

119 Lopus decolor (FALL.)

\section{SYMPHYTA}

1 Xyela julii (BREB.)

2 Acantholyda posticalis (MATs.)

3 Cephalcia arvensis (PAnz.)

4 Pamphilius hortorum (KLUG)

5 Pamphilius marginatus (LEP.)

6 Pamphilius sylvaticus (L.)

7 Pamphilius varius (LEP.)

8 Janus femoratus (CURT.)

9 Janus luteipes (LEP.)

10 Arge dimidiata (FAll.)

11 Arge ustulata (L.)

12 Microdiprion pakkipes (FALL.)

13 Macrophya duodecimpunctata (L.)

14 Eriocampa ovata (L.)

15 Athalia bicolor LEP.

16 Athalia circularis (KLUG)

17 Athalia cordata LEP.

18 Athalia cordatoides PRIESN.

19 Athalia glabricollis THOMsoN

20 Athalia lugens (KL.ug)

21 Athalia rosae (L.)

22 Monosoma pulveratum (RETz.)

23 Empria longicornis (Thomson)

24 Ametastegia equseti (FAl..) 
25 Ametastegia glabrata (FALL.)

26 Ametastegia tener (SPINOLA)

27 Allantus cingillum (KLUG)

28 Allantus togatus (PAnz.)

29 Harpiphorus lepidus (KLUG)

30 Monophadnus pallescens (GMEL.)

31 Stethomostus fulginosus (SCHRк.)

32 Eutomostethus luteiventris (KLUG)

33 Periclista albida (KLUG)

34 Claremontia alternipes (KLUG)

35 Claremontia confusa (KoN.)

36 Diprion similis (HART.)

37 Gilpinia polytoma (HART.)

38 Gilpinia virens (KuG)

39 Gilpinia frutetorum (FABR.)

40 Strongylogaster lineata (CHRIST)

41 Strongylogaster macula (KLuG)

42 Strongylogaster mixta (KLUG)

43 Aneugmenus padi (L.)

44 Birka cinereipes (KLuG)

45 Nesoselandria morio (FABR.)

46 Selandria serva (FABR.)

47 Dolerus gessneri ANDRE

48 Aglaostigma fulvipes (Scop.)

49 Tenthredopsis excisa (THомson)

50 Tenthredopsis fresei (KoN.)

51 Tenthredopsis litterata (GEOFF.)

52 Tenthredopsis nassata (L.)

53 Tenthredopsis scutellaris (FABR.)

54 Rhogogaster picta (KıUG)

55 Rhogogaster viridis (L.)

56 Tenthredo atra (L.)

57 Tenthredo livida (L.)

58 Tenthredo maculata (GEOFF.)

59 Halidamia affìnis (FALL.)

60 Caliroa cinxia (KLUG)

61 Hetererthrus nemoratus (FALL.)

62 Hetererthrus ochropodus (KL.uG)

63 Hetererthrus vagans (FALL.)

64 Scolioneura betuleti (KLug)

65 Messa glaucopis (Kon.)

66 Messa nana (KLuG)

67 Profenusa pygmaea (Kuvg)

68 Profenusa thomsoni (Kon.)

69 Fenusa dohrnii (Tisch.)

70 Fenusa pusilla (LeP.)

71 Cladius pectinicornis (GEOFF.)

72 Priophorus morio (LEP.)
73 Priophorus pallipes (LEP.)

74 Hoplocampa flava (L.)

75 Hoplocampa testudinea (KLUG)

76 Mesoneura opaca (FABr.)

77 Dineura viridorsata (RETz.)

78 Hemichroa australis (LEP.)

79 Hemichroa crocea (GeofF.)

80 Nematinus lutens (PAnz.)

81 Pristiphora cincta (NEwMAN)

82 Pristiphora conjugata (DHLB.)

83 Pristiphora melanocarpa (HART.)

84 Pristiphora pallidiventris (FAL.L.)

85 Pristiphora ruficornis (Ot.rv.)

86 Pristiphora subbifida (Тном.)

87 Pristiphora testacea (JURINE)

88 Pristiphora alpestris (Kon.)

89 Pristiphora mollis (HART.)

90 Pristiphora abietina (CHRIST)

91 Pristiphora compressa (HART.)

92 Pristiphora decipiens (ENSL.)

93 Pristiphora gerula (Kon.)

94 Pristiphora leucopodia (HART.)

95 Pristiphora pallida (KoN.)

96 Pristiphora pseudodecipiens (B \& K)

97 Pristiphora sexesenii (HART.)

98 Pristiphora tenuicornis (LINDguIsT)

99 Pristiphora tenuiserra (LinDguist)

100 Sharliphora amphibola (FOEIRSTER)

101 Sharliphora nigella (FOERSTER)

102 Sharliphora parva (HART.)

103 Pikonema insigne (HART.)

104 Pikonema montanum (ZADD.)

105 Pikonema nigriceps (HART.)

106 Pikonema pallescens (HART.)

107 Pikonema scutellatum (HART.)

108 Croesus septentrionalis (L.)

109 Nematus princeps (ZADD.)

110 Nematus cadderensis CAM.

111 Nematus dispar BRISCH.

112 Nematus umbratus THом.

113 Nematus viridis STEPH.

114 Euura mucronata (HART.)

115 Potania coriacea (BENS.)

\section{CURCULIONIDAE}

1 Rhinomacer attelaboides $\mathrm{F}$.

2 Doydirhynchus austriacus (OLIv.)

3 Pselaphorhynchites longiceps (Tномs.) 
4 Pselaphorhynchites nanus (РАYK.)

5 Deporaus betulae (L.)

6 Deporaus mannerheimi (Нимм.)

7 Attelabus nitens (Scop.)

8 Apoderus coryli (L.)

9 Apion curtirostre GERM.

10 Apion simile KIRBY

11 Apion virens HERBST

12 Apion fulvipes (GEOFFr.)

13 Otiorhynchus ovatus (L.)

14 Phyllobius arborator (HERBST)

15 Polydrusus pallidus (Gri...)

16 Polydrusus pilosus GREDL.

17 Brachyderes incanus (L.)

18 Strophosoma capitatum (DEG.)

19 Sitona lineatus (L.)

20 Hypera zoilus (Scop.)

21 Hypera nigrirostris (F.)

22 Anthonomus phyllocola (HERBST)

23 Brachonyx pineti (PAYK.)

24 Curculio rubidus GrL.

25 Curculio pyrrhoceras MARSH.

26 Magdalis exarata (BRIs.)

27 Magdalis phlegmatica (HERBST)

28 Magdalis nitida (GYLL.)

29 Magdalis linearis (GYLL.)

30 Magdalis violacea (L.)

31 Magdalis duplicata Germ.

32 Hylobius abietis (L.)

33 Pelenomus quadricorniger (COLONN.)

34 Rhinoncus bruchoides (HERBST)

35 Rhinoncus castor (F.)

36 Coeliodes rubicundus (HERBST)

37 Ceutorhynchus pleurostigma (MrSH.)

38 Ceutorhynchus assimilis (РАҮК.)

39 Ceutorhynchus erysimi (F.)

40 Ceutorhynchus punctiger (GrL...)

41 Ceutorhynchus floralis (РАYK.)

42 Anoplus plantaris (NAEZ.)

43 Rhynchaenus avellanae (DoNOv.)

44 Rhynchaenus rusici (HERBST)

45 Rhynchaenus stigma (GERM.)

46 Rhamphus pulicarius (HERBST)

\section{CHRYSOMELIDAE}

1 Cryptocephalus flavipes FABR.

2 Cryptocephalus parvulus MUEL.

3 Cryptocephalus pini (LinN.)
4 Cryptocephalus punctiger PAYK.

5 Cryptocephalus pusillus FABR.

6 Cryptocephalus saliceti ZEBE

7 Plagiodera versicolora (Laich.)

8 Chrysomela lapponica L.

9 Phratora atrovirens (CORNEL.)

10 Phratora laticollis (SUFFr.)

11 Phratora vitellinae (L.)

12 Phratora vulgatissima (L.)

13 Galerucella lineola (FABR.)

14 Galerucella calmariensis (L.)

15 Phyllotreta vittula (REDT.)

16 Phyllotreta nemorum (L.)

17 Phyllotreta undulata Kursch.)

18 Phyllotreta flexuosa (h.s.)

19 Phyllotreta vittata (F.)

20 Aphthona euphorbiae (SCHRANK)

21 Longitarsus longiseta WEISE

22 Longitarsus nasturtii (F.)

23 Longitarsus parvulus (PAYK.)

24 Altica quercetorum Foudr.

25 Asiorestia ferruginea (SCOP.)

26 Chaetocnema heikertingeri LuUB.

27 Chaetocnema hortensis (GEOFFR.)

\section{LEPIDOPTERA}

Tortricidae

1 Acleris laterana (F.)

2 Acleris sparsana (Den. et Schiff.)

3 Acleris maccana (TRErT.)

4 Eana incanana (STEPH.)

5 Cnephasia communana (H.-S.)

6 Cnephasia stephensia (DouBL.)

7 Cnephasia asseclana (DEN. et SCHIFF.)

8 Cnephasia genitalana (PIERCE et MECT.)

9 Capua vulgana FroL.

10 Ramapesia gnomana (CLERCK)

11 Argyrotaenia ljugiana (THNBG.)

12 Archips oporanus (L.)

13 Archips xylosteanus (L.)

14 Archips rosanus (L.)

15 Choristoneura diversana (HBN.)

16 Ptycholoma lecheana (L.)

17 Pandemis cerasana (HBN.)

18 Syndemis musculana (HBN.)

19 Adoxophys orana (F. v. R.)

20 Hedya atropunctana (ZETT.)

21 Cymolomia hartigiana (SAx.) 
22 Orthotaenia undulana (DEN. et SCHIFF.)

23 Pseudohermenias abietana (FABR.)

24 Apotomis turbidana (HBN.)

25 Apotomis betuletana (HAw.)

26 Olethreutes bifasciana (Haw.)

27 Olethreutes lacunana (DEN. et ScHIFF.)

28 Ancylis laetana (F.)

29 Ancylis upupana (Trert.)

30 Ancylis badiana (DEn. et Schiff.)

31 Ancylis unculana (HAw.)

32 Ancylis apicella (DEN. et SCHIFF.)

33 Epinotia solandriana (L.)

34 Epinotia tenerana (DEN. et SCHIF.)

35 Epinotia tedella (CLERCK)

36 Rhopobota naevana (HBN.)

37 Spilonota ocellana (DEN. et ScHIFF.)

38 Blastesthia turionella (L.)

39 Rhyacionia buoliana (DEN. et ScHiff.)

40 Rhyacionia pinicolana (DouBL.)

41 Rhyacionia pinivorana (LIEN. et ZELL.)

42 Rhyacionia duplana (HBN.)

43 Retinia resinella (L.)

44 Pammene obscurana (STEPH.)

45 Pammene argyrana (HBN.)

46 Cydia cosmophorana (TREIT.)

47 Cydia coniferana (SAX.)

Choreutidae

48 Anthophila fabriciana (L.) Pyralidae

49 Assara terebrella (Zinck.)

50 Crambus lathoniellus (ZiNCK.)

51 Crambus ericellus (HBN.)

52 Crambus heringiellus (H.-S.)

53 Agriphila inquinatella (DEN. et SCHFF.)

54 Catoptria margaritella (DEN. et SCHIFF.)

55 Scoparia basistrigalis KnAGgS

56 Eudonia truncicolella (STT.)

57 Eurrhypis pollinalis (DEN, et SCHIFF.)

58 Udea lutealis (HBN.) Zygenidae

59 Adscita statices (L.) Pieridae

60 Pieris napi (L.)

61 Pieris brassicae (L.)

62 Gonepteryx rhamni (L.) Lycaenidae

63 Quercusia quercus (L.)

64 Callophrys rubi (L.)
65

cycaena virgaureae (L.)

Lycaena tityrus (PODA)

Plebejus argus (L.)

Nymphalidae

68 Nymhalis polychloros (L.)

69 Inachis io (L.)

70 Aglais urticae (L.)

71 Araschnia levana (L.)

72 Issoria lathonia (L.)

73 Boloria dia (L.)

74 Boloria euphrosyne (L.)

75 Melitaea athalia (Rotr.) Satyridae

76 Aphantopus hyperantus (L.)

77 Coenonympha pamphilus (L.)

78 Coenonympha arcania (L.)

79 Pararge aegeria (L.)

Thyatiridae

80 Thyatira batis (L.)

81 Tethea or (DEN. et SCHIFF.)

82 Tetheella fluctuosa (HBN.)

Geometridae

83 Jodis putata (L.)

84 Cyclophora punctaria (L.)

85 Scopula nigropunctata (HUFN.)

86 Scopula floslactata (Haw.)

87 Idaea straminata (ВоRкн.)

88 Xanthorrhoe spadiceraria (DEN. et ScHIFF.)

89 Xanthorrhoe quadrifasciata (CLERCK)

90 Xanthorrhoe montanata (DEN. et SCHIFF.)

91 Chloroclysta citrata (L.)

92 Chloroclysta truncata (HUFN.)

93 Thara obeliscata (HBN.)

94 Thera variata (DEN. et SCHIFF.)

95 Therajuniperata (L.)

96 Electrophaes corylata (THnBG.)

97 Hydriomena furcata (THNBG.)

98 Rheumaptera undulata (L.)

99 Euphyia unangulata (HAw.)

100 Epirrita autumnata (ВоRКн.)

101 Perizoma alchemillata (L.)

102 Perizoma hydrata (Trerr.)

103 Eupithecia plumbeolata (HAw.)

104 Eupithecia venosata (FABR.)

105 Eupithecia intricata (ZETT.)

106 Eupithecia subfuscata (Haw.)

107 Eupithecia indigata (HвN.)

108 Eupithecia pusillata (DEN. et SCHIFF.) 
109 Eupithecia tantillaria (BSDv.)

110 Chloroclystis debiliata (HBN.)

111 Semiothisa liturata (CLERCK)

112 Alcis repandata (L.)

113 Ematurga atomaria (L.)

114 Bupalus piniarius (L.)

115 Hylaea fasciaria (L.)

116 Gnophos obscurata (DEN. et SCHIFF.) Notodontidae

117 Drymonia obliterata (EsP.)

118 Ptilodon capucina (L.)

Lymantriidae

119 Lymantria monacha (L.) Arctiidae

120 Eilema deplana (Esp.) Herminuidae

121 Herminia strigillata (L.) Noctuidae

122 Rivula sericealis (Scop.)

123 Hypena crassalis (F.)

124 Hypena proboscidalis (L.)

125 Catocala fraxini (L.)

126 Catocala sponsa (L.)

127 Laspeyria flexula (DEN. et SCHIFF.)

128 Protodeltote pygarga (HuFN.)

129 Autographa gamma (L.)

130 Acronicta aceris (L.)

131 Amphipyra pyramidea (L.)

132 Dypterygia scabriuscula (L.)

133 Trachea atriplicis (L.)

134 Euplexia lucipara (L.)

135 Enargia paleacea (Esp.)

136 Apamea crenata (HUFN.)

137 Apamea remissa (HBN.)

138 Oligia strigilis (L.)

139 Oligia latruncula (DEN. et SCHIFF.)

140 Mesoligia furuncula (DEN. et SCHFF.)

141 Mesapamea secalis (L.)

142 Celaena leucostigma (HвN.)

143 Archanara geminipuncta (Haw.)

144 Lithophane furcifera (HUFN.)

145 Conistra vaccinii (L.)

146 Agrochola helvola (L.)

147 Polia bombycina (HufN.)

148 Polia tincta (BRAHM)

149 Polia nebulosa (Hurn.)

150 Mamestra brassicae (L.)

151 Melanchra persicariae (L.)
152 Lacanobia thalassina (HUFN.)

153 Lacanobia suasa (DEN, et SCHIFF.)

154 Orthosia incerta (HUfN.)

155 Mythimna albipunctata (DEN. et SCHIFF.)

156 Mythimna pallens (L.)

157 Euxoa nigricans (L.)

158 Agrostis ipsilon (HuFN.)

159 Eugraphe subrosea (STEPH.)

160 Diarsia brunnea (DEN, et SCHIFF.)

161 Xestia c-nigrum (L.)

162 Xestia baja (DEN. et SCHIFF.)

163 Eurois occulta (L.)

164 Anaplectoides prasina (DEN. et SCHFF.)

SCOLYTIDAE

1 Hylurgops palliatus (GYLL.)

2 Hylastes ater (PAYK.)

3 Hylastes opacus ER.

4 Hylurgus lignipedra (FABR.)

5 Tomicus minor (HART.)

6 Tomicus piniperda (L.)

7 Pityogenes bidentatus (HERBST)

8 Pityogenes chalcographus (L.)

9 Pityogenes quadridens (HART.)

10 Pityogenes trepanatus (NORDL.)

11 Orthotomicus laricis (F.)

12 Orthotomicus proximus (Еіснн.)

13 Orthotomicus suturalis (GvL.)

14 Ips acuminatus (Еіснн,)

15 Ips sexdentatus (BORN.)

16 Dryocoetes autographus (RATz.)

17 Crypturgus cinereus (HERBST)

18 Crypturgus hispidulus (Tномs.)

19 Crypturgus pusillus (GrL..)

20 Trypodendron lineatum (OLIv.)

21 Pityophthorus lichtensteini (RATz.)

22 Pityophthorus pityographus (RATz.)

\section{CERAMBYCIDAE}

I Prionus coriarius (L.)

2 Tetropium castaneum (L.)

3 Tetropium fuscum (F.)

4 Spondylis buprestoides (L.)

5 Arhopalus rusticus (L.)

6 Asemum striatum (L.)

7 Molorchus minor (L.)

8 Callidium aeneum (DE GEER)

9 Callidium violaceum (L.) 
10 Callidium coriaceum PAYK.

11 Rhagium mordax (DE GEER)

12 Rhagium inquisitor (L.)

13 Pachyta quadrimaculata (L.)

14 Cortodera femorata (FABR.)

15 Pedostrangalia pubescens (FABR.)

16 Leptura quadrifasciata (L.)

17 Anastrangalia sanguinolenta (L.)

18 Corymbia rubra (L.)

19 Brachyleptura maculicornis (DE GEER)

20 Judolia sexmaculata (L.)

21 Alosterna tabacicolor (DE GEER)

22 Strangalia attenuata (L.)

23 Stenurella melanura (L.)

24 Stenurella nigra (L.)

25 Monochamus galloprovincialis (OLIv.)

26 Monochamus sutor (L.)

27 Monochamus urussovii (Fisch.)

28 Pogonocherus fasciculatus (DE GEER)

29 Pogonocherus decoratus (FAIRM.)

30 Acanthocinus griseus (FABR.)

31 Acanthocinus aedilis (L.)

32 Leiopus nebulosus (L.)

33 Saperda populnea (L.)

\section{BUPRESTIDAE}

1 Chalcophora mariana (L.)

2 Buprestis haemhorroidalis HERBST

3 Buprestis novemmaculata (L.)

4 Buprestis octoguttata (L.)

5 Buprestis rustica (L.)

6 Phaenops cyanea FABR.

7 Anthaxia quadripunctata (L.)

8 Anthaxia similis (SAUND)

9 Anthaxia submontana (OBENB.)

10 Agrilus angustulus (ItL.)

11 Agrilus sulcicollis (LACORD.)

12 Trachys minuta (L.)

\begin{tabular}{ll}
\multicolumn{1}{c}{ ASILIDAE } \\
1 & Choerades fimbriata (MG.) \\
2 & Dioctria humeralis (ZELL.) \\
3 & Dioctria hyalipennis (F.) \\
4 & Dioctria oelandica (L.) \\
5 & Lasiopogon cinctus (F.) \\
6 & Lasiopogon immaculatus STR. \\
7 & Cyrtopogon lateralis (FLL.) \\
8 & Leptogaster pubicornis (Lw.)
\end{tabular}

9 Dysmachus cochleatus (Lw.)

10 Dysmachus picipes (MG.)

11 Dysmachus trigonus (MG.)

12 Epitriptus arthriticus (ZLL.)

13 Epitriptus cingulatus (F.)

14 Neoitamus cothurnatus (MG.)

15 Neoitamus cyanurus (Lw.)

16 Neoitamus socius (Lw.)

17 Neomochtherus pallipes (MG.)

18 Pamponerus germanicus (L.)

19 Paritamus geniculatus (MG.)

20 Tolmerus atricapillus (FLL.)

21 Tolmerus atripes Lw.

22 Tolmerus pyragra (ZLL.)

ARANEI

1 Anyphaena accentuata (WALCK.)

2 Dictyna arundinacea (L.)

3 Dictyna pusilla TH.

4 Cicurina cicurea MG.

5 Arctosa cinerea (F.)

6 Xerolycosa nemoralis (WESTR.)

7 Drassodes pubescens (Тн.)

8 Micaria silesiaca L. K.

9 Phrurolithus festivus (C.L.K.)

10 Micrommata roseum (CL.)

11 Clubiona lutescens WESTR.

12 Euryclubiona stagnatilis (KUL.)

13 Euryclubiona subsultans (ТH.)

14 Ballus chalybeius (WLK.)

15 Dendryphanthes hastatus (C.L.)

16 Dendryphanthes rudis (SuND.)

17 Heliophanus aeneus (HAHN)

18 Heliophanus dubius (C.L.K.)

19 Heliophanus flavipes (HAHN)

20 Marpissa muscosa CL.

21 Neon reticulatus (BLACK.)

22 Phlegra v-incignita (CL.)

23 Pseudicius encarpatus (WALCK.)

24 Salticus oleari (Scop.)

25 Coriarachne depressa (C.L.K.)

26 Diaea dorsata (F.)

27 Xysticus cristatus (CL.)

28 Xysticus lanio C.L.K.

29 Artanes dispar (WALCK.)

30 Horodromoides fuscomarginatus (DE GEER)

31 Philodromus aureolus (CL.)

32 Philodromus collinus (C.L.K.) 
33 Araneus angulatus (CL.)

34 Araneus diadematus (CL.)

35 Araniella cucurbitina (CL.)

36 Araniella incospicua (SıM.)

37 Atea sturmi (HAHN)

38 Gibbaranea bituberculata (WALck.)

39 Mangora acalypha (WALCK.)

40 Nuctenea umbratica (CL.)

41 Pachygnatha clercki SUND.

42 Tetragnatha pinicola $\mathrm{K}$.

43 Agyneta rurestris (C.L.K.)

44 Centromerus sylvaticus (BL.)

45 Drapetisca socialis (SUND.)

46 Kaestneria dorsalis (WID.)

47 Leptyphanthes flavipes (BL.)

48 Leptyphanthes obscurus (BL.)

49 Porrhomma convexum (WESTR.)

50 Porrhomma pygmaeum (BLACK)

51 Ceratinella brevis (WIDER.)

52 Diplocephalus hiemalis F. DAut.

53 Dismodicus cornutus (B⿺..)

54 Dismodicus elevatus PETR. nec C.L.K.

55 Entelecara congenera (O.P-C.)

56 Erigone atra (BL.)

57 Erigone dentipalpis (WIDER.)

58 Gongylidiellum compar (WESTR.)

59 Metopobactrus prominulis (O.P-C.)

60 Moebelia penicillata (WESTR.)

61 Oedothorax gibbosus (Bt..)

62 Peponocranium orbiculatum (O.P-C.)

63 Savignya frontata $\mathrm{BL}$.

64 Tapinocyba pallens (O.P-C.)

65 Trematocephalus cristatus (WiD.)

66 Crustulina guttata (WiD.)

67 Dipoena tristis (HAHN)

68 Enoplognatha ovata (CL.)

69 Neottiura bimaculata (L.)

70 Theridion mystaceum (L.K.)

71 Theridion pictum (WALCK.)

72 Theridion pinastri (L.K.)

73 Theridion sisyphium (CL.)

74 Theridion tinctum (WALCK.)

75 Theridion varians HAHN.

\section{SPHECIDAE}

(* gatunki afidofagiczne)

1 Podalonia affinis KIRBY

2 Ammophila campestris LATR.
3 Ammophila luffi SAund.

4 Ammophila pubescens CURT.

5 Ammophila sabulosa (L.)

6 Mimumesa unicolor LiND.

7 Psenulus concolor (DAHLB.)

8 Psenulus fuscipennis (DAнцв.) *

9 Psenulus laevigatus (Sснск.)

10 Psenulus pallipes (PAnz.) *

11 Pemphredon balticus (MERISUO) *

12 Pemphredon lethifer (Sсниск.) *

13 Pemphredon lugubris (F.) *

14 Pemphredon morio Lind. *

15 Pemphredon shuckardi (A. Mor.) *

16 Passaloecus borealis DAнL. *

17 Passaloecus brevilabris *

18 Passaloecus clypealis FAEST. *

19 Passaloecus corniger Sнuск. "

20 Passaloecus eremita KоHL. *

21 Passaloecus gracilis (CURT.) *

22 Passaloecus insignis (Lind.) *

23 Passaloecus monilicornis DAHLB. *

24 Passaloecus singularis DAHLB. *

25 Passaloecus turionum DAнLв. *

26 Spilomena beata BLUTHG.

27 Spilomena differens BLUTHG.

28 Spilomena punctatissima BLuTHG.

29 Spilomena troglodytes (LiND.)

30 Spilomena vagans BLUTHG.

31 Tachysphex obscuripennis (SCHENC.)

32 Tachysphex pompiliformis (PANz.)

33 Tachysphex psammobius (КонL)

34 Nitela spinolae LATR. *

35 Trypoxylon attenuatum SмrTH

36 Trypoxylon clavicerum LEP. et SERV.

37 Trypaxylon figulus (L.)

38 Trypaxylon medium BEAUMONI

39 Trypoxylon minus BEAUMONT

40 Entomognatus brevis (LIND.)

41 Lindenius albilabris (F.)

42 Lindenius panzeri (LIND.) *

43 Rhopalum clavipes (L.) *

44 Rhopalum coarctatum (Scop.)

45 Crossocerus annulipes (LEP. et BRUL.)

46 Crossocerus barbipes (DAн.B.)

47 Crossocerus cetratus SHuck. *

48 Crossocerus dimidiatus (F.)

49 Crossocerus inermis thoms.

50 Crossocerus megacephalus (Ros.) 
Crossocerus nigritus (LEP. et BRUL.)

53 Crossocerus palmipes (L.)

54 Crossocerus pusillus LEP. et BRUL.

55 Crossocerus quadrimaculatus (F.)

56 Crossocerus styrius (KонL)

57 Crossocerus walkeri (Sниск.)

58 Crossocerus wesmaeli (LIND.) *

59 Crabro cribrarius (L.)

60 Crabro peltarius (SCHREB.)

61 Crabro scutellatus (SCHEv.)

62 Ectemnius cavifrons (THомs.)

63 Ectemnius cephalotes (Ourv.)

64 Ectemnius continuus (F.)

65 Ectemnius lapidarius (PAnz.)

66 Ectemnius ruficornis (ZETT.)

67 Ectemnius sexcinctus (F.)

68 Lestica clypeata (SCHREB.)

69 Lestica subterranea $(\mathrm{F}$.

70 Mellinus arvensis (L.)

71 Nysson niger CHEVR.

72 Nysson spinosus (J. Forst.)

73 Nysson trimaculatus (Rossi)

74 Alysson fuscatus (PAnz.)

75 Argogorytes mystaceus (L.)

76 Cerceris arenaria (L.)

77 Cerceris quadrifasciata (PAnz.)

\section{COCCINELLIDAE}

1 Scymnus haemorrhoidalis HERBST

2 Scymnus suturalis THUNB.

3 Scymnus nigrinus KUGEL.

4 Exochomus quadripustulatus (L.)

5 Aphidecta obliterata (L.)

6 Adalia conglomerata (L.)

7 Adalia decempunctata (L.)

8 Coccinella septempunctat (L.)

9 Harmonia quadripunctata (PoNT.)

10 Myrrha octodecimpunctata (L.)

11 Calvia decemguttata (L.)

12 Calvia quatuordecimpunctata (L.)

13 Mysia oblogoguttata (L.)

14 Anatis ocellata (L.)

\section{CANTHARIDAE}

1 Cantharis decipiens BAUDI

2 Cantharis flavilabris FALL.

3 Cantharis livida rufipes HERBST
4 Cantharis nigricans (O. F. MulL.)

5 Cantharis obscura L.

6 Cantharis pellucida $\mathrm{F}$.

7 Cantharis rufa L.

8 Cantharis rustica Fall.

9 Rhagonycha atra (L.)

10 Rhagonycha elongata (FAlL.)

11 Rhagonycha fulva (Scop.)

12 Rhagonycha lignosa (O.F. MuL..)

13 Rhagonycha limbata Tномs.

14 Silis nitidula $(\mathrm{F}$ )

15 Malthinus biguttatus (L.)

16 Malthinus facialis Tномs.

17 Malthinus frontalis (MARSH.)

18 Malthinus punctatus (FourCr.)

19 Malthodes brevicollis (PAYK.)

20 Malthodes crassicornis (MAEKL.)

21 Malthodes guttifer KIESENW.

22 Malthodes mysticus KIESENw.

23 Malthodes pumilus (BREB.)

\begin{aligned} & \multicolumn{1}{c}{ SYRPHIDAE } \\ & (* gatunki zoofagiczne) \\ & 1 Eristalis arbustorum (L.) \\ & 2 Eristalis tenax (L.) \\ & 3 Eristalis rupium F. \\ & 4 Eristalis nemorum (L.) \\ & 5 Eristalis horticola (DEG.) \\ & 6 Eristalinus sepulchralis (L.) \\ & 7 Myathropa florea (L.) \\ & 8 Helophilus pendulus (L.) \\ & 9 Helophilus hybridus LOEW \\ & 10 Helophilus parallelus HARR. \\ & 11 Helophilus affinis WHALB. \\ & 12 Helophilus lineatus (F.) \\ & 13 Parhelophilus versicolor (F.) \\ & 14 Helophilus lunulatus MEIG. \\ & 15 Parhelophilus frutetorum (F.) \\ & 16 Lathyrophtalmus aeneus (ScOP.) \\ & 17 Eumerus strigatus (FALL.) \\ & 18 Temnostoma bombylans (F.) \\ & 19 Temnostoma vespiforme (L.) \\ & 20 Temnostoma apiforme (F.) \\ & 21 Xylota segnis (L.) \\ & 22 Xylota tarda MEIG. \\ & 23 Chalcosyrphus piger (F.) \\ & 24 Xylota femorata (L.) \\ & 25 Xylota sylvarum (L.) \end{aligned}

SYRPHIDAE

(* gatunki zoofagiczne)

Eristalis arbustorum (L.)

3 Eristalis rupium F.

4 Eristalis nemorum (L.)

Eristalis horticola (DEG.)

6 Eristalinus sepulchralis (L.)

7 Myathropa florea (L.)

8 Helophilus pendulus (L.)

9 Helophilus hybridus LOEW

10 Helophilus parallelus HarR.

11 Helophilus affunis WHALB.

12 Helophilus lineatus (F.)

13 Parhelophilus versicolor (F.)

14 Helophilus lunulatus MEIG.

15 Parhelophilus frutetorum (F.)

16 Lathyrophtalmus aeneus (Scop.)

17 Eumerus strigatus (FALL.)

18 Temnostoma bombylans (F.)

19 Temnostoma vespiforme (L.)

20 Temnostoma apiforme (F.)

21 Xylota segnis (L.)

22 Xylota tarda MeIG.

3 Chalcosyrphus piger (F.)

25 Xylota sylvarum (L.) 
26 Xylota abiens MEIG.

27 Xylota florum (F.)

28 Chalcosyrphus nemorum (F.)

29 Xylota ignava (PAnz.)

30 Syritta pipiens (L.)

31 Lejota ruficornis (ZETT.)

32 Triglyphus primus LOEW *

33 Pipizella varipes (MEIG.) *

34 Neocnemodon fulvimanus (ZETT.) *

35 Neocnemodon vitripennis (MEIG.) *

36 Pipiza quadrimaculata (PAnz.) *

37 Cheilosia pagana (MEIG.)

38 Cheiosia ruralis (MEIG.)

39 Cheilosia vernalis (FALL.)

40 Cheilosia chloris (Meig.)

41 Orthoneura nobilis (FALL.)

42 Orthoneura geniculata MEIG.

43 Orthoneura intermedia LUNDB.

44 Orthoneura frontalis LOEW

45 Chrysogaster viduata (L.)

46 Didea intermedia LoEw *

47 Didea fasciata MAcg. *

48 Didea alneti (FAlL.) *

49 Scaeva pyrastri (L.) *

50 Scaeva selenitica (MEIG.)*

51 Dasysyrphus albostriatus (FALL.) *

52 Dasysyrphus venustus (MEIG.) *

53 Syrphus torvus O.-S. *

54 Episyrphus balteatus (DEG.)

55 Metasyrphus corollae (F.) *

56 Syrphus vitripennis MEtG. *

57 Syrphus ribesii (L.) *

58 Parasyrphus lineolus (ZETT.) *

59 Meligramma cincta (FAL...) *

60 Meliscaeva cinctella (ZETr.) *

61 Metasyrphus latifasciatus (MAcg.) *

62 Meligramma guttata (FALL.) *

63 Dasysyrphus tricinctus (FALL.) *

64 Epistrophe eligans HarR. *

65 Melanostoma mellinum (L.) *

66 Melanostoma scalare (F.) *

67 Sphaerophoria scripta (L.) *

68 Sphaerophoria menthastri (L.) *

69 Sphaerophoria philanthus MEIG. *

70 Xanthogramma citrofasciatum (DEG.) *

71 Platycheirus albimanus (F.) *

72 Platycheirus peltatus (MEIG.)*

73 Platycheirus clypeatus (MEIG.) *
74 Xanthandrus comtus (HARR.) *

75 Melangyna quadrimaculata (VERR.) *

76 Baccha elongata (F.) *

77 Baccha obscuripennis MEıG. *

78 Neoascia dispar (Meıg.)

79 Neoascia aenea (MEIG.)

80 Neoascia floralis (MEIG.)

81 Neoascia geniculata (MEIG.)

82 Chrysotoxum vernale LOEW*

83 Chrysotoxum festivum (L.) *

84 Chrysotoxum elegans LOEW *

85 Chrysotoxum octomaculatum CURT. *

86 Brachyopa panzeri GoFfE

87 Brachyopa scutellaris RoB.-DEsv.

88 Microdon devius (L.)

89 Blera fallax (L.)

90 Sericomyia lappona (L.)

91 Sericomyia silentis HARR.

\section{NEUROPTEROIDEA}

1 Raphidia ophiopsis ophiopsis L.

2 Raphidia notata $\mathrm{F}$.

3 Raphidia xanthostigma Sснимм.

4 Inocellia crassicornis (SСHUмm.)

5 Coniopteryx parthenia (NAv. et MARC.)

6 Conventzia pineticola END.

7 Wesmaelius concinnus (STEPH.)

8 Wesmaelius nervosus (F.)

9 Wesmaelius mortoni (Mc LACHL.)

10 Hemerobius humulinus L.

11 Hemerobius stigma STEPH.

12 Hemerobius pini STEPH.

13 Hemerobius fenestratus TJED.

14 Hemerobius nitidulus $\mathrm{F}$.

15 Hemerobius micans OLIV.

16 Sympherobius fuscescens (WALL.)

17 Nineta vittata (WESM.)

18 Chrysopa perla (L.)

19 Chrysopa septempunctata WESM.

20 Mallada prasinus (Burm.)

2 I Mallada ventralis (CURT.)

22 Chrysoperla carnea (STEPH.)

23 Cunctochrysa albolineata (KIL..)

TACHINIDAE

1 Acemyia rufitibia (VON ROSER)

2 Actia crassicornis (MEIG.)

3 Actia nudibasis (STEIN) 
4 Actia pilipennis (FALL.)

5 Admontia blanda (FALL.)

6 Admontia podomyia (B. \& B.)

7 Aplomyia confinis (FAL.L.)

8 Appendicia truncata (ZETT.)

9 Athrycia curvinervis (ZETT.)

10 Athrycia trepida (MEıg.)

11 Bactromyia aurulenta (MEIG.)

12 Bessa parallela (MEIG.)

13 Bessa selecta (MEIG.)

14 Blepharomyia angustifrons HERT.

15 Blepharomyia pagana (MEIG.)

16 Blepharomyia piliceps (ZETT.)

17 Blondelia nigripes (FALL.)

18 Bothria subalpina VilL.

19 Brachychaeta stigata (HEIG.)

20 Campylochaeta inepta (MEIG.)

21 Carcelia (C.) bombylans R.-D.

22 Carcelia (C.) gnava (MEIG.)

23 Carcelia (C.) rasa (MAcg.)

24 Carcelia (Euryclea) tibialis (R.-D.)

25 Caracelina stackelbergi (MESN.)

26 Ceranthia abdominalis (R.-D.)

27 Ceranthia lichtwardtiana (VILL.)

28 Ceranthia pallida Hert.

29 Ceromyia monstrosicornis (STEIN)

30 Ceromyia silacea (MEIG.)

31 Cylindromyia brassicaria (FABR.)

32 Cylindromyia pilipes (LOEw)

33 Cyzenis albicans (FALL.)

34 Cyzenis jucunda (MEig.)

35 Chaetoptilia puella (RoND.)

36 Compsilura concinnata (MEıG.)

37 Dexiosoma canina (FABR.)

38 Dinera ferina (FALL.)

39 Drino bohemica MEsN.

40 Drino inconspicua (MEIG.)

41 Elfia cingulata (R.-D.)

42 Elfia nigroaenea HERT.

43 Eloceria delecta (MEIG.)

44 Entomophaga nigrohalterata (VILL.)

45 Eriothrix accolus Kol.

46 Eriothrix monochaeta WAINWR.

47 Eriothrix rufomaculata (DE GEER)

48 Ernestia rudis (FALL.)

49 Ernestia vagans (MEIG.)

50 Erycilla ferruginea (MEIG.)

51 Eurithia connivens (ZETT.)
52 Eurithia consobrina (MEIG.)

53 Eurithia juncta (ZIM.)

54 Eumea linnearicornis (ZETT.)

55 Eurysthaea scutellaris (R.-D.)

56 Hebia flavicornis R.-D.

57 Hemyda vittata (MEIG.)

58 Huebneria affinis (FALL.)

59 Linnaemyia tessellans (R.-D.)

60 Loewia foeda (MEIG.)

61 Loewia phaeoptera (MEıg.)

62 Lydina aenea (MEIG.)

63 Lydella stabulans (MEIG.)

64 Lypha dubia (FALL.)

65 Macquartia grisea (FALL.)

66 Macquartia tenebricosa (MEIG.)

67 Masicera silvatica (FALL.)

68 Medina collaris (FAL.L.)

69 Medina luctuosa (MEIG.)

70 Medina melania (MEtg.)

71 Medina multispina HERT.

72 Medina separata (MEIG.)

73 Meigenia incana (FALL.)

74 Myxexoristops blondelli(R.-D.)

75 Ocytata pallipes (FALL.)

76 Oswaldia eggeri (B. \& B.)

77 Oswaldia muscaria (FALL.)

78 Parasetigena silvestris (R.-D.)

79 Parathryphera barbatula (RoND,)

80 Peletachina tibialis (FAL.L.)

81 Peribaea fissicornis (STROBL)

82 Peribaea apicalis R.-D.

83 Phorinia aurifrons R.-D.

84 Phryxe erythrostoma (HART.)

85 Phryxe magnicornis (ZETT.)

86 Phryxe nemea (MEIG.)

87 Platymyia fimbriata (MEIG.)

88 Platymyia mitis (MEıg.)

89 Prosopea nigricans (EGG.)

90 Pseudopachystylum gonioides (ZETT.)

91 Pseudoperichaeta nigrolineata (WALK.)

92 Pales pumicata (MEıg.)

93 Phebellia glauca (MEIG.)

94 Phorocera obscura (FAli..)

95 Rondania fasciata (MAcg.)

96 Senometopia excisa (FALL.)

97 Siphona flavifrons STAEg.

98 Siphona confusa MESN.

99 Siphona cristata (FABR.) 
100 Siphona maculata StAEg.

101 Siphona rossica MESN.

102 Siphona setosa MESN.

103 Smidtia conspersa (MEıg.)

104 Tachina magnicornis (ZETr.)

105 Thelaira nigripes (FABR.)

106 Timavia amoena (Meig.)

107 Triarthria setipennis (FALL.)

108 Vibrissina turrita (MEIG.)

109 Voria ruralis (FALL.)

110 Winthemia cruentata (RoND.)

111 Winthemia variegata (MEIG.)

\section{PIPUNCULIDAE}

1 Nephrocerus scutellatus (MAcg.)

2 Chalarus fumbriatus $\mathrm{COE}$

3 Verrallia villosa (V. Roser)

4 Eudorylas subfascipes Colt.

5 Tomosvariella sylvatica (MG.)

6 Pipunculus zugmmeyerie Kow.

7 Pipunculus spinipes MG.

8 Cephalops semifumosus (Kow.)

9 Cephalops aeneus FAL...

\section{ICHNEUMONIDAE}

Protichneumonini

1 Coelichneumon deliratorius (L.)

2 Coelichneumon desinatorius (Тнимв.)

3 Coelichneumon falsificus (WESM.)

4 Coelichneumon fasciatus (GMEL.)

5 Coelichneumon sugillatorius (L.) Heresiarchini

6 Heresiarches eudoxius (WESM.) Listrodonini

7 Anisobas platystylus (Tномs.) Acanthojoppini

8 Pseudoplatybalus uniguttatus (GRAv.)

9 Pseudoplatybalus violentus (GRAv.) Ichneumonini

10 Stenichneumon culpator (SCHRANK)

11 Syspasis alboguttatus (GRAv.)

12 Syspasis eburnifrons (WESM.)

13 Syspasis scutellartor (GRAv.)

14 Stenoaopius pictus (Grav.)

15 Aoplus defraudator (WESM.)

16 Aoplus ochropis (GMEL.)

17 Platylabops virginalis (WESM.)

18 Stenobarichneumon basalis (PERK.)
19 Lymantrichneumon dispar (PODA)

20 Cratichneumon culex (MuLL.)

21 Cratichneumon fabricator (F.)

22 Cratichneumon palliditarsus (Тном.)

23 Cratichneumon punctifrons (GRAv.)

24 Cratichneumon rufifrons (GRAv.)

25 Cratichneumon sicarius (GRAv.)

26 Cratichneumon versator (Тнчмв.)

27 Cratichneumon viator (ScOP.)

28 Eupalamus lacteator (GRAv.)

29 Eupalamus oscillator (WESM.)

30 Eupalamus wesmaeli (Tномs.)

31 Crypteffigies lanius (GRAv.)

32 Homotherus locutor (Thumв.)

33 Homotherus varipes (GRAv.)

34 Eristicus clarigator (WESM.)

35 Vulgichneumon bimaculatus (ScHRANK.)

36 Vulgichneumon deceptor (Scop.)

37 Vulgichneumon saturatorius (L.)

38 Virgichneumon? albosignatus (GRAV.)

39 Virgichneumon diagrammus (GRAV.)

40 Virgichneumon dumeticola (GRAv.)

41 Virgichneumon extremator (Тнимв.)

42 Virgichneumon faunus (GRAv.)

43 Virgichneumon maculicauda (РЕRK.)

44 Virgichneumon monostagon (GRAv.)

45 Barichneumon praeceptor (Тнимв.)

46 Barichneumon? "penversus KRIECHB."

47 Barichneumon? plagiarius (WESM.)

48 Chasmias motatorius (F.)

49 Ichneumon albicollis WESM.

50 Ichneumon cessator MuLL.

51 Ichneumon extensorius L.

52 Ichneumon grasilentus WESM.

53 Ichneumon insidiosus WESM.

54 Ichneumon latrator $\mathrm{F}$.

55 Ichneumon lugens Grav.

56 Ichneumon melanotis HoMGR.

57 Ichneumon memorator WESM.

58 Ichneumon minutorius DEsv.

59 Ichneumon nereni Thомs.

60 Ichneumon sarcitorius L.

61 Ichneumon subquadratus THомs.

62 Limerodops elongatus (BRISCHKE)

63 Ctenichneumon funereus (GEOFFr.)

64 Ctenichneumon divisorius (Grav.)

65 Diphyus amatorius (MuLL.)

66 Diphyus luctatorius (L.) 
67

68 Spilichneumon ammonius (GRAv.) Platylabini

69 Platylabus nigrocyaneus (Grav.)

70 Poecilosticus cothurnatus (GRAv.)

71 Cyclolabus nigricollis (WESM.)

72 Lincyus exhortator (F.) Phaeogenini

73 Eriplatys ardeicollis (WESM.)

74 Eriplatys sawoniewiczi (DILLER)

75 Hemichneumon elongatus (RATZ.)

76 Trachyarus corvinus Tномs.

77 Stenodontus marginellus (GRAv.)

78 Dicaelotus crassifemur Tном.

79 Dicaelotus inflexus Tномs.

80 Dicaelotus pumilus (Grav.)

81 Dicaelotus rufilimbatus (GRAv.)

82 Deloglyptus pictus ScHMiED.

83 Diadromus subtilicornis (GRAv.)

84 Diadromus troglodytes (GRAv.)

85 Colpognathus celerator (GRAv.)

86 Aetheurus discolor WESM.

87 Aetheurus nitidus WESM.

88 Phaeogenes melanogonos (GMEL.)

89 Phaeogenes spiniger (Grav.)

90 Dirophanes callopus (WESM.)

91 Dirophanes maculicornis (STEPH.)

92 Dirophanes fulvitarsis (WESM.)

93 Tycherus amoenus (WESM.)

94 Tycherus clypearis (BRISCHKE)

95 Tycherus coriaceus (PERK.)

96 Tycherus dodecellae RANIN

97 Tycherus cf. jucundus (WESM.)

98 Tycherus ophtalmicus (WESM.)

99 Tycherus osculator (Тнимв.)

100 Tycherus vagus (BERTH.)

101 Tycherus verecundus RANIN

102 Epitomus infuscatus (GRAv.)

103 Misetus oculatus (WESM.)

\section{ENCHYTRAEIDAE}

1 Mesenchytraeus pelicensis ISSEL.

2 Mesenchytraeus sp. Eis.

3 Buchholiza simplex NIEL. et CHRIST.

4 Buchholiza sp. MıcH.

5 Buchholiza ehlersi UdE

6 Cognettia sphagnetorum (VEJD.)

7 Marionina sp. Mich.
8 Fridericia ratzeli Eıs.

9 Fridericia sp. Мich.

10 Achaeta sp. VEJD.

\section{COLLEMBOLA}

Hypogastruridae

1 Schoetella ununguiculata (TULL.)

2 Xenylla brevicauda TullB.

3 Xenylla boerneri AxEL.

4 Willemia anophthalma BORNER

5 Willemia aspinata STACH

6 Hypogastrura sp. j.

Neanuridae

7 Pseudachorutes parvulus BORNER

8 Microanurida pygmaea BORNER

9 Neanura muscorum (TEMPL.)

Onychiuridae

10 Oligapphorura absoloni (BORNER)

11 Propaphorura armata (TULLB.)

12 Propaphorura subuliginatus GIsIN

13 Propaphorura furcifera (BORNER)

14 Mesaphorura macrochaeta RUSEK

15 Mesaphorura yossi RUSEK

Isotomidae

16 Anurophorus laricis STACH

17 Anurophorus septentrionalis PALISSA

18 Folsomia quadrioculata (Tull.B.)

19 Proisotoma minima (ABs.)

20 Isotomiella minor (SCHAFF.)

21 Isotoma notabilis SCHAFF.

22 Isotoma hiemalis ScHotT

23 Isotoma tigrina (Nıc.)

24 Isotoma sp. j.

25 Vertagopus cinereus (Nic.)

26 Pachyotoma sp.n.

Entomobryidae

27 Orchesella flavescens (BourL.)

28 Entomobrya nivalis (L.)

29 Entomobrya sp. j.

30 Lepidocyrtus cyaneus TUL.в.

31 Lepidocyrtus lignorum (FABR.)

32 Lepidocyrtus sp. $\mathbf{j}$.

33 Pseudosinella zygophora (SCHILLE)

34 Cyphoderus albinus Nic.

35 Pogonognathellus flavescens (TuLLB.)

36 Tomocerus sp. $\mathrm{j}$

Sminthuridae

37 Lipothrix lubbocki (TULLB.) 
38 Allacma fusca (L.)

Bourletiellidae

39 Bourletiella hortensis (FrrcH)

\section{NEMATODA}

1 Rhabditis s. L.

2 Bunonema reticulatum RicHT.

3 Heterocephalobus elongatus (DE MAN)

4 Acrobeloides nanus (DE MAN)

5 Ypsylonellus insubricus (STEIN.)

6 Teratocephalus dadayi ANDR.

7 Teratocephalus tenuis ANDR.

8 Metateratocephalus crassidens (DE MAN)

9 Filenchus ditissimus (BRz.)

10 Malenchus bryophilus (STEIN.)

11 Ditylenchus anchilisposomus TARIAN

12 Ditylenchus equalis Heins

13 Ditylenchus longimatricalia (KAz.)

14 Geocenamus longus (Wu)

15 Helicotylenchus pseudorobustus STEIN.

16 Paratylenchus nanus Совв.

17 Aphelenchoides spp.

18 Seinura winchesi GoODEY

19 Paraphelenchus sp.

20 Eymonhystera sp.

21 Geomonchystera sp.

22 Plectus geophilus DE MAN

23 Plectus longicaudatus (Bur.)

24 Plectus pusteri Fuchs

25 Wilsonema otophorum (DE MAN)

26 Prodesmodora terricola MiCOLETZKY

27 Alaimus mucronatus ALtH.

28 Prionchulus punctatus (CоBB.)

29 Mesodorylaimus sp.

30 Eudorylaimus silvaticus BRz.

31 Aporcelaimellus sp.

32 Tylencholaimus mirabilis BuT.

33 Tylencholaimus stecki STEIN

\section{FORMICIDAE}

1 Myrmica ruginodis NrL.

2 Myrmica scabrinodis NYL.

3 Myrmica sabuleti MEIN.

4 Myrmica lobicornis NYL.

5 Myrmica schencki Ем.

6 Leptothorax acervorum (FABR.)

7 Leptothorax muscorum (NYL.)

8 Tetramorium caespitum (L.)
9 Strongylognathus testaceus (SCHENCK)

10 Camponotus herculeanus (L.)

11 Lasius niger (L.)

12 Lasius flavus (FABR.)

13 Lasius umbratus umbratus (NYL.)

14 Lasius fuliginosus (LATR.)

15 Formica fusca L.

16 Formica truncorum F.

17 Formica rufa L.

18 Formica polyctena FOERST.

19 Formica sanguinea (LATR.)

THEREVIDAE

1 Acrosathe annulata (F.)

2 Cliorismia ardea (F.)

3 Dialineura anilis (L.)

4 Spiriverpa lunulata (ZETT.)

5 Thereva cinifera (MEıG.)

6 Thereva fulva (MEIG.)

7 Thereva circumscripta Lw.

8 Thereva handlirschi KROEBER

9 Thereva lanata ZETT.

10 Thereva microcephala Lw.

11 Thereva inornata VERR.

12 Thereva nobilitata (F.)

13 Thereva strigata (F.)

14 Thereva plebeja (L.)

\section{RHAGIONIDAE}

1 Rhagio lineola (F.)

2 Rhagio scolopaceus (L.)

3 Rhagio tringarius (L.)

\section{MICROMAMMALIA}

Rodentia

Arvicolidae

1 Clethrionomys glareolus (SCHREB.)

2 Pitymys subterraneus (S.-L.)

3 Microtus agrestis (L.)

4 Microtus arvalis (PALLAS)

5 Microtus oeconomus (PALLAS) Muridae

6 Micromys minutus (PALLAS)

7 Apodemus agrarius (PALLAS)

8 Apodemus flavicollis (MELCH.)

9 Apodemus sylvaticus (L.) Zapodidae

10 Sicista betulina (PALLAS) 
Insectivora

Soricidae

11 Sorex araneus (L.)

12 Sorex caecutiens Laxmann

13 Sorex minutus (L.)

14 Neomys anomalus (CABR.)

15 Neomys fodiens (SCHREB.)

AVES

Passeriformes

Alaudidae

1 Lullula arborea (L.)

Motacillidae

2 Anthus trivialis (L.)

Troglodytidae

3 Troglodytes troglodytes (L.)

Prunellidae

4 Prunella modularis (L.)

Turdidae

5 Erithacus rubecula (L.)

6 Phoenicurus phoenicurus (L.)

7 Turdus merula (L.)

8 Turdus philomelos (C. L. BREHM)
Sylvidae

9 Sylvia atricapilla (L.)

10 Sylvia borin (BoDD.)

11 Phylloscopus collybita (VIEILL.)

12 Phylloscopus sibilatrix (BECHST.)

13 Phylloscopus trochilus (L.)

14 Regulus regulus (L.) Aegithalidae

15 Aegithalos caudatus (L.) Paridae

16 Parus ater (L.)

17 Parus cristatus (L.) Certhiidae

18 Certhia familiaris (L.) Fringillidae

19 Fringilla coelebs (L.)

20 Carduelis spinus (L.)

21 Pyrrhula pyrrhula (L.) Emberizidae

22 Emberiza citrinella (L.) Picidae

23 Dendrocopos major (L.) .

STRESZCZENIE

[Tytuł: Sukcesja wtórna fauny w borach świeżych Puszczy Białowieskiej]

Bory sosnowe Polski ze względu na wartości użytkowe drewna sosnowego eksploatowane sa i uprawiane od setek lat. Na większość z nich składaja się drzewostany jednowiekowe, powstałe najczęściej w wyniku sztucznego odnowienia zrębów zupełnych. Założenie na porębie uprawy sosny, zwykle z domieszka drzew towarzyszących bądź osłonowych, uruchamia proces sukcesji wtórnej. W jej trakcie bór przechodzi przez kilka etapów: uprawy, młodnika. tyczkowiny, dragowiny, drzewostanu dojrzewającego aż do stadium dojrzałości. Proces ten, w przypadku borów sosnowych świeżych, trwa w naszych warunkach 10-150 lat (SZUJECKI 1980).

Każdy z tych etapów charakteryzuje siẹ nieco odmiennymi warunkami mikroklimatu leśnego, zależnie od składu drzewostanu i właściwości siedliska (OBMINSKI 1978). Zmiany te znajduja swe odzwierciedlenie w przebudowie szaty roślinnej. Tu procesy sukcesji wtórnej w borach świeżych Puszczy Białowieskiej maja charakter wybitnie kreatywny. Prowadza bowiem do uformowania 
struktury przestrzennej boru o wyrażnej piętrowości, a przestrzeń życiowa wnetrza lasu jest zapełniona przez gatunki dopasowane do uformowanych w toku sukcesji wtórnej warunków środowiska. Jest to proces powtarzalny, obserwowany i opisany dla siedlisk borowych z różnych regionów kraju.

Procesy te w odniesieniu do fauny rozpoznane sa fragmentarycznie, a dokumentacja sukcesji wtôrnej fauny obejmuje tylko poszczególne grupy zwierząt i nie pozwala na stworzenie pełnego obrazu przemian zachodzacych w składzie i organizacji kompleksów faunistycznych. Na tle dość bogatego, lecz czessto słabo powiazanego z realiami przyrodniczymi, piśmiennictwa poświeconego tematyce sukcesji ekologicznej autorzy niniejszego opracowania postawili szereg pytań dostosowanych do charakteru materialôw faunistycznych, więc takich, ktôre dają mózliwość uzyskania udokumentowanej odpowiedzi.

Podstawowa w naszym rozumieniu tematu kwestia jest charakter sukcesji wtórnej fauny, czyli jak i do czego ona prowadzi. Nie jest bowiem oczywiste, tak jak w przypadku szaty roślinnej boru, że w procesie sukcesji wtórnej ma miejsce wyraźny rozwój biomasy zwierzat i uformowanie się struktur przestrzennych. Zjawiska takie, jeśli nawet mają miejsce wymagają udokumentowania. Na czoło wysuwa się kwestia jednotorowości czy wielotorowości procesu sukcesji wtôrnej fauny. Chodziło tu o sam model procesu. Czy jest on w pelni kreatywny, a jego etapy polegaja na zasiedlaniu pustki ekologicznej, formowaniu podsystemów i dopasowywaniu ich do ekologicznej struktury dojrzewajacego lasu. Ten klarowny obraz budzi szereg watpliwości. Czy istnieje bowiem przez jakiś okres pustka faunistyczna po wyciẹciu lasu, czy té̇ otwarta przestrzeń jest natychmiast zasiedlana? Czy poszezególne podsystemy zoocenozy dopiero się formuja, czy sa już gotowe w przyrodzie? I w końcu, na czym ma polegać owo dopasowywanie, lub dokladniej, do czego w rzeczywistości dopasowuja się poszczególne grupy fauny?

Dla uzyskania jednoznaczej odpowiedzi na postawione pytania zbudowano dwie hipotezy robocze, ktore stanowily nastepnie podstawe do weryfikacji w oparciu o zebrane i opracowane materiały.

Hipoteza pierwsza określa, że sukcesja wtórna fauny może mieć rozmaity przebieg i prowadzić do odmiennych niekiedy układów końcowych. Opisano pięć typów przebiegu sukcesji: kreatywny, stabilizujacy, załamany, regresywny i restauracyjny (Fig. 3).

Hipoteza druga określa powiazania fauny w system zależności troficznych o charakterze hierarchicznym. Zgodnie z nia zrab struktury fauny stanowia powiazane zależnościami pokarmowymi układy takie jak podsystem, lańcuch pokarmowy, zespôł konkurencyjny i populacja określonego gatunku zwierzat. Zależności te przedstawiono w odniesieniu do 30 grup fauny objętej programem badań dla stadium końcowego sukcesji wtórnej. fauny starodrzewu boru sosnowego świeżego.

Tak sformułowane hipotezy robocze pozwoliły na konfrontacje danych o faunie z wyobrażeniami o przebiegu sukcesji wtórnej. Jako materiału do weryfikacji hipotez użyto materiałôw dokumentacyjnych dla poszczególnych klas wieku lasu: 1) liczbę gatunków tworzacych poszczególne taksoceny lub zespoły 
konkurencyjne: 2) liczebność tych jednostek, zwykle ujmowaną wskaźnikowo dla zobrazowania tendencji zmian liczebności; 3) strukturę taksocenów dla zobrazowania zmian $\mathrm{w}$ organizacji układôw zoocenotycznych: 4) różnorodność gatunkowa aktualna i potencjalną oraz zachodzacy między nimi stosunek mierzony wskaźnikiem Pielou.

Liczba gatunków (Tab. II) w toku sukcesji wtórnej borỏw sosnowych świeżych w Puszczy Białowieskiej wykazuje zmiany idące w sześciu kierunkach. Dominuje typ sukcesji restauracyjnej charakteryzujacy się wysoka liczba gatunkow w uprawach sosny, spadkiem w fazie dragowiny i odbudowa w starodrzewie. Ten typ przebiegu został stwierdzoy w połowie zbadanych zespołów konkurencyjnych i 8 taksocenach. Na drugim pod względem udziału miejscu znalazły się dwa dalsze typy przebiegu sukcesji wtórnej. Sukcesja regresywna, polegająca na spadku liczby gatunków w całym szeregu sukcesji występuje w obrębie 4 zespolów i 5 taksocenów zwierzat. Podobnie sukcesja zalamana, w której po początkowym wzroście ma miejsce spadek liczby gatunków została stwierdzona w 5 zespołach konkurencyjnych. Sukcesja kreatywna charakteryzujaca się stałym wzrostem liezby gatunków w szeregu sukcesyjnym wystapila tylko w obrębie 4 zespolów konkurencyjnych. Stabilizacja liczby gatunków po początkowym ich wzroście miała miejsce tylko w 2 zespołach zwierzat. Poza tymi 5 typami zmian liczby gatunków należy wymienić 5 przypadków braku zmian liczby gatunków w toku procesów rozwoju boru. Taki stan rzeczy stwierdzono dla stonkowatych (Chrysomelidae), afidofagicznych biedronek (Coccinellidae). pasożytniczych muchówek Pipunculidae, nicieni (Nematoda) i Rhagionidae (Diptera).

Podobny obraz zróżnicowania reakcji poszczególnych grup zwierzat na proces odbudowy boru świeżego ma miejsce przy rozpatrywaniu poszczególnych zespołôw konkurencyjnych (Tab. II). Tam, gdzie mamy do czynienia z kilkoma taksonami wchodzacymi w skład zespolu, zazwyczaj każdy $z$ nich prezentuje odmienny kierunek zmian liczby gatunków. Wyjatek pod tym względem stanowia zoofagi oraz ksylo-i kambiofagi, wśród których dominuje restauracyjny kierunek zmian liczby gatunków. Natomiast wśród fitofagôw zgryzających przeważaja tendencje spadkowe w odniesieniu do liczby gatunkôw w toku sukcesji wtórnej.

Wynik analizy zmian w tworzywie organizacji ekosystemu leśnego, jaki stanowia gatunki zwierzat, wskazuje na to, że procesy twórcze rozbudowy lub odbudowy układów, reprezentowane przez typ sukcesji kreatyunej. stabilizujaccej i restauracyjnej są równie silne jak procesy destrukcyjne wyrażajace się w ostatecznym rachunku spadkiem liczby gatunków. Znamienne jest przy tym, że co 6 grupa zwierząt nie reaguje zmiana liczby gatunków na procesy zachodzace $w$ rozwijajacym się borze. Liczebność zgrupowań zwierzat (Tab. III) przedstawia równie zróżnicowany obraz przebiegu zmian jak liczba gatunków, jednak dwa kierunki procesów sa dominujace: regresja i restauracja. Około $1 / 3$ zgrupowań zwierząt startuje do procesu sukcesji z wieksza liczebnościa populacji niż w drzewostanach dojrzałych, dominuje wiẹc spadek liczebności. Na drugim miejscu znajduja się te zgrupowania, których spadek zostaje w toku sukcesji zatrzymany i w drzewostanach starszych ma miejsce wzrost liczebności populacji. Tylko co 7 taksocen wykazuje wzrost liczebrości 
populacji w całym szeregu sukcesji i taka sama liczba grup nie wykazuje zmian liczebności utrzymując się w całym szeregu sukcesji na tym samym poziomie zageszczenia. Co 15 taksocen po poczatkowym wzroście liczebności wchodzi w fazę spadku, zaś tylko 1 taksocen wśród saprofagów, mianowicie skoczogonki (Collembola) ma przebieg liczebności wskazujacy na stabilizacje zgrupowania w drzewostanach starszych.

Zjawiska te rozpatrywane od strony poszezególnych zespołów konkurencyjnych wykazuja wyraźne rozstrzelenie reakeji liczebności w ich obrębie. W każdym zespole bezkręgowców spotykamy obok siebie taksoceny wykazujące, jedne wzrost, drugie spadek liczebości. Wyjatek pod tym względem stanowią niewyspecjalizowane zoofagi, wśród których dominuja tendencje spadku liczebności.

Analiza zmian liczebności fauny pozwala na uzyskanie odpowiedzi odnośnie dwôch ważnych kwestii związanych z sukcesja wtórną borów sosnowych świeżych. Pojęcie "pustki faunistycznej" nie odpowiada rzeczywistości przyrodniczej. Poręba leśna zostaje natychmiast zasiedlona przez populacje zwierzat o wysokiej liczebności, niemal $2 / 3$ zgrupowań zwierzat w toku sukcesji zaniża swa liczebność w stosunku do jej stanu w uprawach sosny.

Wzrost liezebności wykazuje tylko 1 / 4 zespołów zwierzecych (Tab. III), sa to fitofagi ssace, afidofagi i ptaki. Liczebność stanowi miare sukcesu ekologicznego zarówno gatunku jak i zgrupowania zwierzẹcego. W toku sukcesji wtórnej boru sosnowego świeżego ma miejsce zastępowanie systemu eksploatacji produkowanej przez rośliny zielonej masy. Zjadanie igieł sosny przez fitofagi o zgryzajacym aparacie gẹbowym, typowe dla szkodników pierwotnych sosny. wraz z rozwojem lasu ustepuje na rzecz wysysania produktôw asymilacji przez mniej grożne dla lasu fitofagi ssace. Zjawisko to wystẹpuje, w każdym razie w Puszczy Białowieskiej, której bory sosnowe nie sa dotykane klęskowymi pojawami fitofagów zgryzających. Wzrostowi liczebności fitofagów ssacych towarzyszy rozwój zespołôw afidofagów regulujących ich liczebność. Duże znaczenie ma wzrost liczebności zespolów ptaków (w większości owadożernych). które stanowią ogniwo kontrolujace szczególnie podsystem biotrofów.

Różnorodność gatunkowa aktualna (Tab. IV) oceniana miara Shannona i Weavera $\left(\mathrm{H}^{\prime}\right)$ w toku sukcesji wtôrnej boru świeżego wykazuje najbardziej równomierny rozklad typów reakcji. Najczęściej maja miejsce procesy zmniejszania się różnorodności względem jej stanu wyjściowego, jednak sumarycznie, procesy wzrostu różnorodności sa równie częste w zgrupowaniach zwierzęcych jak procesy jej spadku. Znaczny udzial maja również procesy załamywania się różnorodności po okresie wzrostu. Nieco inaczej przedstawia się ta kwestia ogladana od strony wypełniania możliwości potencjalnych rozwoju różnorodności gatunkowej w ekosystemie. Tu procesy zmniejszania się różnorodności, szczególnie w drzewostanach dojrzałych maja charakter dominujacy, stwierdzono je w obrębie 17 zgrupowań zwierzęcych na 28 przeanalizowanych pod tym wzgledem. Wzrost, odbudowa lub stabilizacja różnorodnosci po wzroście dotyczyły tylko $1 / 3$ obserwowanych przypadków. Stabilizacja różnorodności na tym samym poziomie w całym szeregu sukcesji należy do wyjatków. 
Wynik przedstawionej analizy wskazuje wyraźnie, że teza Mac Arthura "diversity makes stability" nie znajduje żadnego odbicia w danych empirycznych (MACARTHUR 1955). Wręcz przeciwnie, spadek różnorodności gatunkowej zgrupowań zwierzat w starodrzewach boru sosnowego wskazuje na to, że wzrost stopnia organizacji układu odbywa się kosztem zmniejszenia jego różnorodności wewnętrznej. Ma to ścisły związek ze zjawiskami strukturalnymi. W drzewostanach starych, zazwyczaj w każdym zgrupowaniu zwierzęcym jest jeden lub parę gatunków wyraźnie dominujących, "ogon" gatunków akcesorycznych ulega zwykle skróceniu. Organizacja zgrupowania oparta jest zwykle na kilku dobrze dostosowanych gatunkach budujacych zespoły zwierzęce.

W zakończeniu należy podkreślić, że cecha najbardziej charakterystyczna sukcesji wtórnej fauny w borach sosnowych świeżych Puszczy Białowieskiej jest wielokierunkowość procesów zachodzących na tle rosnącego, rozwijającego swa strukturę przestrzenną boru świeżego. Jeśli wziać pod uwage przeanalizowane parametry: liczbę gatunków, liczebność, różnorodność gatunkowa i strukturę, to dominujące znaczenie maja procesy spadku wartości wskaźników, w całym szeregu sukcesji lub w jej koncowej fazie (44\% przypadków). Stabilizacja tych wartości w całym szeregu lub po okresie wzrostu obejmuje tylko $22 \%$ przypadków. Tylko w $34 \%$ przypadków obserwujemy rozwój od początku sukcesji do stadium dojrzałego lub po okresie spadku w środkowym stadium.

Dane te potwierdzaja hipotezę o wielokierunkowości przebiegu procesów sukcesji wtórnej w obrębie zgrupowań fauny. Szczególne znaczenie ma spadek wartości wielu wskaźników charakteryzujących faunę w końcowym etapie sukcesji, który można określić jako fazę organizacji zgrupowań, która odbywa się kosztem redukcji liczby gatunków i różnorodności na rzecz ustabilizowania struktur dominacyjnych. Tak więc stabilność ekosystemów tworza lepiej przystosowani, a różnorodność jest jej budulcem nie wykorzystanym w pełni.

Cały układ zoocenotyczny powstaje równocześnie już w fazie nasadzania drzewostanu po wyrębie i tu jest najbogatszy. Dalej toczy sie jedynie przebudowa jego organizacji wraz $\mathrm{z}$ rozwojem boru jako ekosystemu. 
1. Introduction . . . . . . . . . . . . . . . . . . . . . . . . . 3

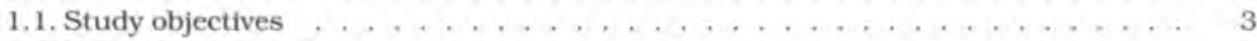

1.2. Review of literature . . . . . . . . . . . . . . . . . 6

2. Area of study . . . . . . . . . . . . . . . . . . . . . . . . . . . . . 7

3. Fauna sampling methods and material ....................... 9

4. Methods for processing data ......................... 11

5. Analysis of secondary succession of the pine forests of Puszcza Białowieska . . . . 13

5.1. A model of the structure of pine forest zoocenosis and the course of secondary succession ............................. 13

5.2. Succession in the subsystem of biotrophs . . . . . . . . . . . . 19

5.2.1. Phytophages . . . . . . . . . . . . . . . . . . . . . . . . 19

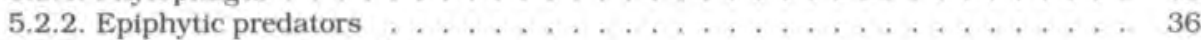

5.2 .3 . Parasitoids of phytophages . . . . . . . . . . . . . . . 51

5.3 . Secondary succession in the saprotrophic subsystem . . . . . . . . 57

5.3 .1 . Soil saprophages . . . . . . . . . . . . . . . . . . . . 57

5.3.2. Pantophages and soil predators ..................... 64

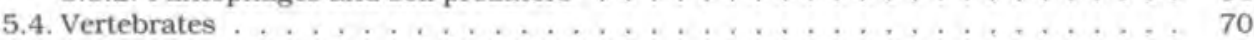

6. Summary . . . . . . . . . . . . . . . . . . . . . 77

7. Bibliography . . . . . . . . . . . . . . . . . . . . . 82

8. An inventory of species occurring in the pine forests of Puszcza Bialowieska . . . . 86 
ISBN 83-85192-37-9

ISSN 0015-9301 